\title{
Prospective zones of unconventional hydrocarbon reservoirs in the Cambrian, Ordovician and Silurian shale formations of the East European Craton marginal zone in Poland
}

\author{
Teresa PODHALAŃSKA ${ }^{1, *}$, Anna FELDMAN-OLSZEWSKA ${ }^{1}$, Joanna ROSZKOWSKA-REMIN ${ }^{1}$, \\ Marcin JANAS ${ }^{1}$, Radomir PACHYTEL ${ }^{1}$, Andrzej GŁUSZYŃSKI ${ }^{1}$ and Michał ROMAN ${ }^{1}$ \\ 1 Polish Geological Institute - National Research Institute, Rakowiecka 4, 00-975 Warszawa, Poland
}

Podhalańska, T., Feldman-Olszewska, A., Roszkowska-Remin, J., Janas, M., Pachytel, R., Głuszyński, A., Roman, M., 2020. Prospective zones of unconventional hydrocarbon reservoirs in the Cambrian, Ordovician and Silurian shale formations of the East European Craton marginal zone in Poland. Geological Quarterly, 64 (2): 342-376, doi: 10.7306/gq.1540

Associate Editor: Stanisław Wołkowicz

The paper presents the latest state of knowledge on the vertical and lateral ranges and characteristics of prospective zones (PZ) within the Lower Paleozoic unconventional hydrocarbon systems in the Baltic-Podlasie-Lublin Basin (Poland). The PZ were identified within the prospective formations based on rigorously determined criteria with the application of stratigraphic, sedimentological, mineralogical, petrographic, geochemical, petrophysical, and geomechanical studies, and interpretations of borehole logs. Archival geological data and information acquired from boreholes drilled recently in concession areas have also been applied in the interpretations. Following these criteria, four prospective zones have been distinguished. The deposits encompass partly or almost completely the Piaśnica, Sasino, and Jantar formations and the lower part of the Pelplin Formation. The characteristic feature of the Lower Paleozoic deposits at the East European Craton (EEC) margin in Poland is the diachronous appearance of the Sasino and Jantar black shale formations from west to east. The Baltic area is most prospective for the occurrence of unconventional hydrocarbon reservoirs in shale formations, specifically the Łeba Elevation, where all 4 prospective zones have been distinguished. The occurrence of liquid and gaseous hydrocarbons is expected in all zones. Due to the very high TOC content and geochemical characteristics, the Piaśnica Formation within PZ1 is the main petroleum source rock in the Polish part of the Baltic Basin. PZ2 (partly corresponding to the Sasino Formation) present in a large part of the Baltic Basin, is the next important prospective unit, despite not being uniform. PZ3 within the Jantar Formation was distinguished only on a limited area of the Łeba Elevation. Due to the low content of organic matter, the Lublin area is characterized by the lowest hydrocarbon potential. However, low values of that parameter are compensated by a greater thickness and lateral range of PZ4, partly corresponding to the Pelplin Formation. Comparison with other areas within the Lower Paleozoic Baltic Basin reveals the occurrence of shale deposits that may constitute a potential source of hydrocarbons, and that demonstrate diachronism. Towards the east and south-east, ever younger deposits possess the potential for hydrocarbon accumulations. In Poland, in the western part of EEC, these are: the Furongian and the Lower Tremadocian Piaśnica Formation, the Sandbian and Katian Sasino Formation and the Lower/Middle Llandovery (Rhuddanian and Aeronian) Jantar Formation. In the central part of the Baltic Basin (Lithuania), these are the Upper Ordovician and Aeronian shale successions. In the southeastern part of the basin (Ukraine), the Ludlow strata are considered to be the most promising in terms of the potential unconventional hydrocarbons accumulations.

Key words: unconventional hydrocarbon systems, prospective zones, Lower Paleozoic, East European Craton, Poland.

\section{INTRODUCTION}

Areas with the highest potential for hydrocarbon exploration and production among unconventional reservoirs in Poland are closely connected with the occurrence of Cambrian, Ordovician, and Silurian fine clastic deposits, extending from

\footnotetext{
* Corresponding author, e-mail: teresa.podhalanska@pgi.gov.pl Received: December 23, 2019; accepted: February 25, 2020; first published online: June 16, 2020
}

the north-west to the south-east of Poland in the East European Craton eastwards of the Teisseyre-Tornquist Zone. The Lower Paleozoic rocks which occur in the Baltic and Podlasie Depressions and the Lublin area represent part of a much more extensive sedimentary cover that was deposited in a pericratonic basin developed on the Precambrian basement of the Baltica palaeocontinent (Fig. 1). The shelf stretched from present-day southern Sweden, the islands of Öland and Gotland, the Baltic States, the Kaliningrad region, northern and eastern Poland, Belarus, as far as western Ukraine. In the Early Paleozoic it was located in middle and low southern latitudes (i.a. Cocks, 2000; Golonka et al., 2019) and in temperate and warm climatic zones with a cold episode in the latest Ordovician. The Baltic Basin (Baltic-Podlasie-Lublin Basin in 


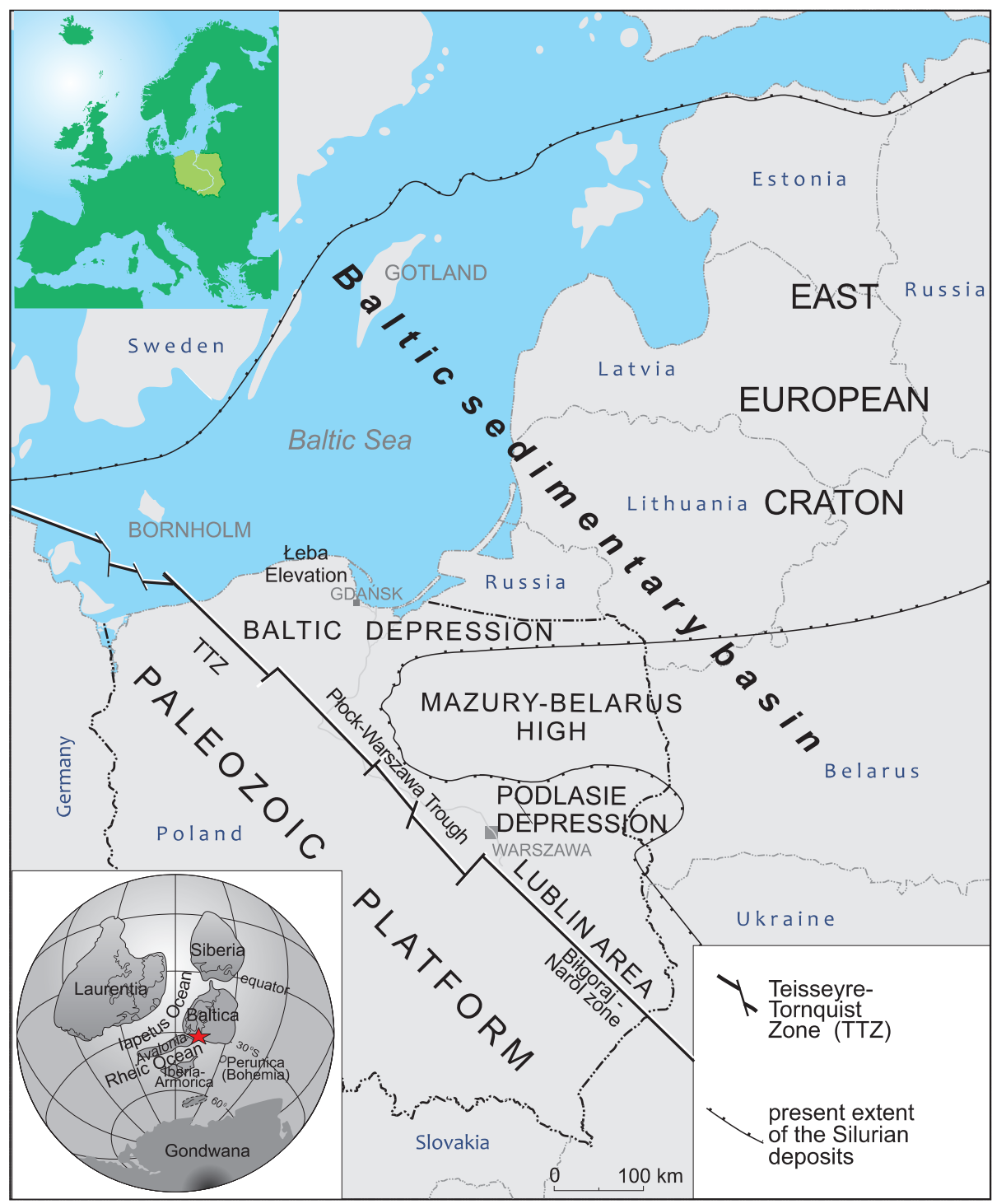

Fig. 1. Location map of the areas investigated in Poland against the major regional tectonic units of the Baltic region (Late Ordovician-Early Silurian palaeogeography after Cocks, 2000)

the area of Poland) was a vast epicratonic sea surrounded by low-gradient shores with slow carbonate and fine clastic sedimentation, many bioclasts, and a belt-like facies distribution representing deep-neritic settings in the west and shallow marine environments in the east, respectively.

Potential source rocks and hydrocarbon occurrences in the Baltic region have been the subject of geological and geochemical research from the early 1990s. The presence of organic-rich shales has prompted oil companies to explore their hydrocarbon potential. From 2009, several reports about perspectives for unconventional hydrocarbon resources in Poland have been published (e.g., Rystad Energy, 2010; EIA, 2011; PIG-PIB, 2012). However there are some issues with those reports and estimations.

First, there are reservations about the estimations in these reports because they based mainly on archival boreholes that were drilled from 1960s to 1990s. The quality of data from these boreholes (geophysical logs, laboratory analysis, condition of archival cores) is often insufficient, so we have collected data from both these archival boreholes and all available new ones drilled from 2010 to 2015 .

Another important problematic issue was that in most of these analyses the total volume of prospective black shale deposits were taken into consideration. After 5 years of intensive prospecting for "shale gas" in Poland, we had the unique opportunity to conduct detailed analysis of a wide spectrum of data obtained mostly from new boreholes. During our research it became obvious that these "prospective" units are not high quality source and reservoir rocks throughout their whole volume. That prompted us to apply objective criteria to indicate the most prospective zones and intervals of black shales within those successions, and in this study we have used the greatest amount of new data from new boreholes to date.

These investigations focused on the stratigraphy, lithology, sedimentology, mineralogy, petrography, geochemistry, petrophysics and interpretations of borehole log data, as well as geo- 
chemical and petrological analyses of organic matter. The studies were based on the results of laboratory analyses, review of all available data from the documentation of boreholes drilled by the Polish Geological Institute - NRI and by oil companies, conveyed to the National Geological Archives, as well as all data obtained and interpreted during the earlier studies (Podhalańska et al., 2016a, b, c; 2018). Complementing this geological information with data obtained from newly drilled boreholes in Poland has allowed to constraint and refinement of the lateral and vertical ranges of earlier depicted prospective zones (Podhalańska et al., 2016b), of the areas of their occurrence, and of parameters used to characterize them. Analysis of the geochemical parameters characterizing organic matter dispersed in four prospective formations (the Piaśnica, Sasino, Jantar and Pelplin formations) constituted the basis of the maps compiled, and this is at present the most up-to-date regional analysis of Lower Paleozoic source rocks in Poland, due to the largest rele-

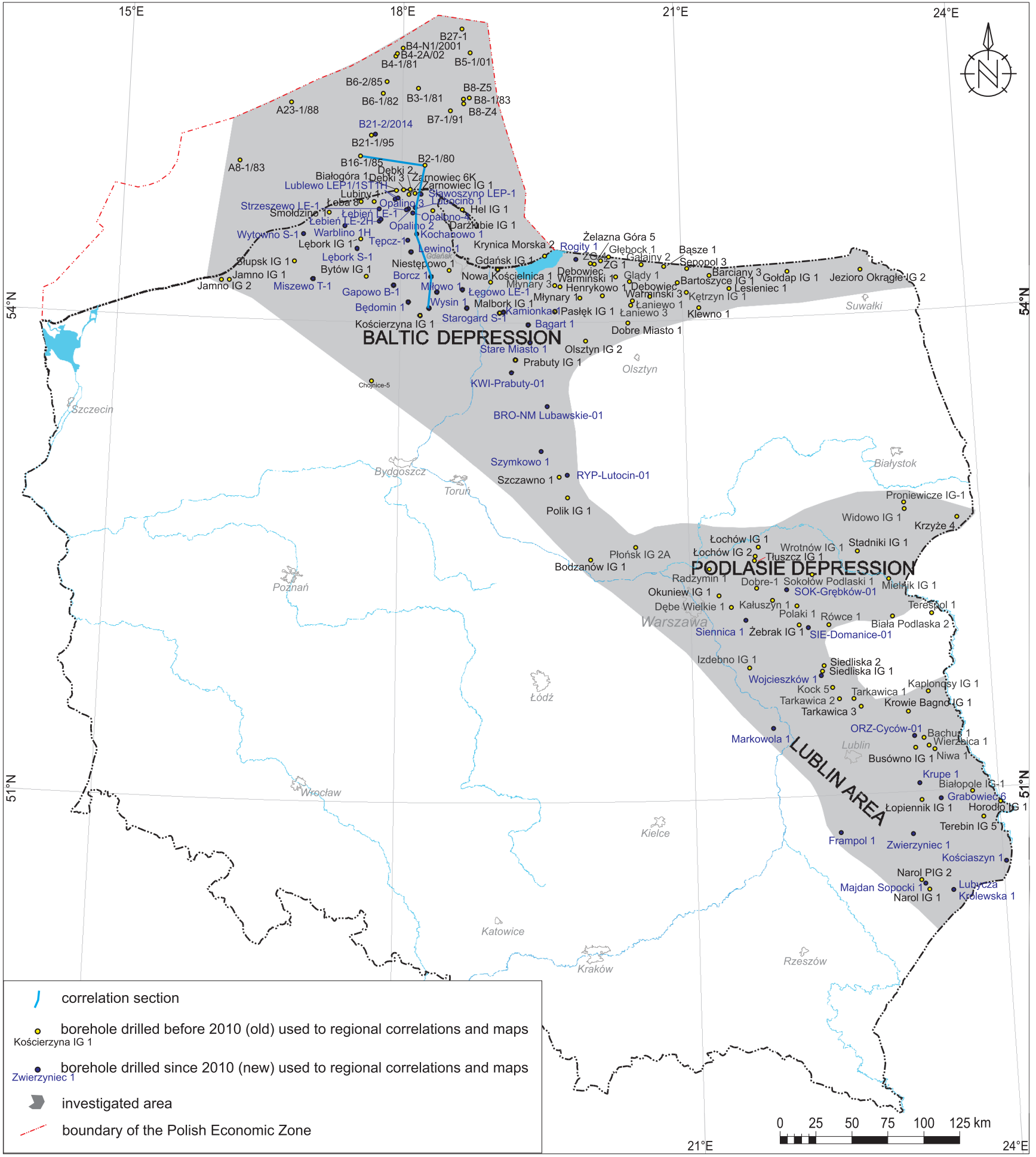

Fig. 2. Location of boreholes used in the research 
vant database being held at the disposal of the Polish Geological Survey.

The distribution of boreholes from which the geological information has been taken is illustrated by the map in Figure 2 .

This paper provides updated ranges and detailed characteristics of prospective zones with the most favourable parameters for hydrocarbon accumulation, distinguished according to objective criteria, within Lower Paleozoic shale formations located in the western part of the EEC in the Baltic and Podlasie depressions and in the Lublin area together with the BiłgorajNarol Zone in Poland. The integrated data is shown as thickness maps of prospective zones and correlation of borehole logs along selected line, with prospective zones marked.

\section{GEOLOGICAL BACKGROUND}

The research focused on Lower Paleozoic shales from northern and eastern Poland occurring in the Baltic Depression - a Variscan tectonic unit located in the EEC - as well as in the Podlasie Depression and the Lublin area (Fig. 1).

The Proterozoic crystalline basement in the study area generally lies between several hundred and 5,000 m depth with a dip to the west and south-west. Three structural stages are distinguished within the craton cover: Lower Paleozoic cover, Permian-Mesozoic cover and Cenozoic cover, all of which show almost no deformation (Fig. 3).
The rocks analysed were formed within a broad pericratonic sedimentary Baltic Basin (Baltic-Podlasie-Lublin Basin in Poland) located along the southwestern margin (in present-day coordinates) of the Baltica palaeocontinent at low southern latitudes. It evolved on a deeply eroded crystalline Proterozoic basement and is filled with deposits dated from the Ediacaran to the Silurian, locally Devonian, in age.

The origin of the basin is related to the Neoproterozoic break-up of the supercontinent Rodinia/Pannotia (Poprawa et al., 1999; Poprawa, 2019; Jaworowski, 2002; Poprawa and Pacześna, 2002). The first depositional sequence in the Polish part of the Baltic Basin (Jaworowski, 2002) contains terrestrial and shallow marine strata related with the syn-rift subsidence of the basin (Poprawa and Pacześna, 2002; Poprawa, 2006). After this stage, the accommodation space in the basin was controlled by low, thermal, post-rift subsidence in a passive margin regime (Poprawa and Pacześna, 2002); such conditions lasted until the Middle Ordovician. In the Late Ordovician, collision between Baltica and Avalonia caused that the Baltic Basin became the distal part of the Caledonian foredeep basin where subsidence was controlled by flexural bending of the southwestern (in present-day coordinates) margin of Baltica. The rate of subsidence reached its maximum in the Late Silurian (Ludlow and Pridoli, see Poprawa et al., 1999; Jaworowski, 2000, 2002; Poprawa and Pacześna, 2002; Poprawa, 2006, 2019).

Deposition in the Baltic Basin was controlled by geotectonic evolution of the south-western margin of Baltica. The pericratonic position of the basin induced a distinct lithofacies

WSW

ENE

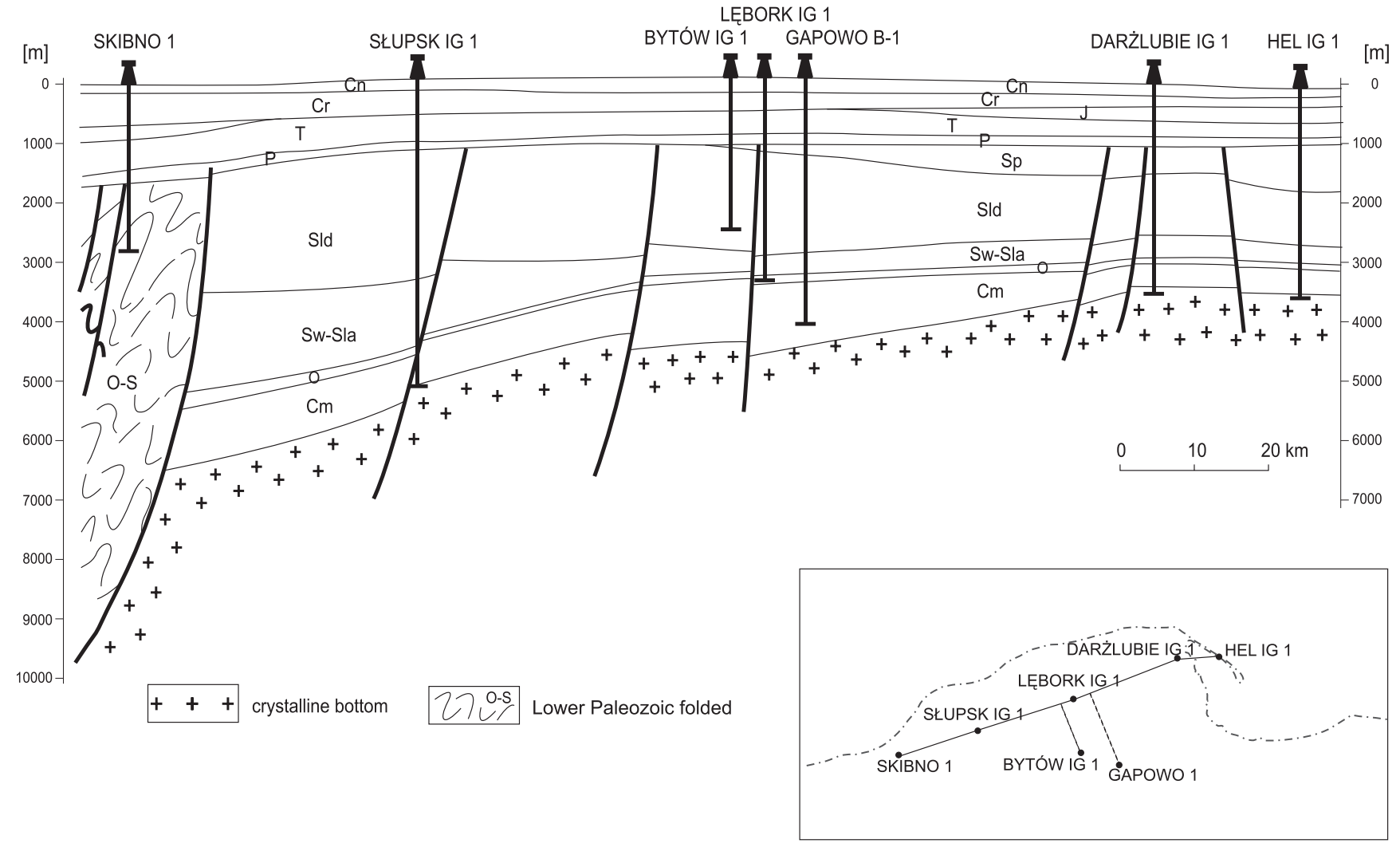

Fig. 3. Schematic geological cross-section of the western part of the Baltic Basin (after Modliński, 2007, 2011; updated) and a location map of boreholes

Cm - Cambrian, O - Ordovician, Sw-Sla - Silurian: Wenlock-Llandovery, Sld - Silurian: Ludlow, Sp - Silurian: Pridoli, P - Permian, $\mathrm{T}$ - Triassic, J - Jurassic, $\mathrm{Cr}$ - Cretaceous, $\mathrm{Cn}$ - Cenozoic 
zonation (e.g., Modliński, 1973, 2010; Jaanusson, 1976; Modliński and Podhalańska, 2010). In general, the eastern part of the basin was dominated by carbonate sedimentation, which was replaced towards the west by prevailing siliciclastic deposition. The second factor that controlled facies development were eustatic sea level changes. From the Cambrian to the Middle Ordovician, the influence of siliciclastic sedimentation towards the east and carbonate sedimentation towards the west were controlled by their position in the transgressive-regressive cycles.

From the Late Ordovician, sedimentation was predominantly controlled by flexural bending of the craton during the Avalonia-Baltica collision, which caused an increase in subsidence and sedimentation rates, and the spread of siliciclastic deposition towards the east (Poprawa et al., 1999; Jaworowski, 2000; Porebski et al., 2013; Mazur et al., 2018). However, the influence of global sea level changes at that time is still visible in facies development. In the upper part of the Upper Ordovician, the Hirnantian, marly and carbonate deposition can be distinguished over most of the basin (Prabuty Formation and its equivalents). This was caused by global sea level fall and reflected the Hirnantian Glaciation on the Gondwana palaeocontinent (Podhalańska, 2009). In the Silurian, the migrating Caledonian collision front determined shale deposition in the basin, and shale and siltstone in the upper part of the succession (e.g., Jaworowski, 2002; Modliński and Podhalańska, 2010; Porębski et al., 2013; Mazur et al., 2018).

\section{PROSPECTIVE ORGANIC-RICH SHALES IN THE BALTIC AND PODLASIE DEPRESSIONS AND LUBLIN AREA}

Four main units of dark organic-rich shales are recognizable within the Lower Paleozoic of the Baltic Basin in Poland (Fig. 4). They belong to four shale formations and three out of four depositional sequences (Jaworowski, 2002; Modliński and Podhalańska, 2010).

Piaśnica Mudstone Formation. This formation occurs in northern Poland on the Łeba Elevation and continues offshore under the Baltic Sea. Deposits of this unit are present in the western part of the Baltic Basin, for example in Sweden and on Bornholm, where they are known as the Alum Shales. Presently, the Piaśnica Formation in Poland (Furongian and Lower Tremadocian) has a narrow lateral extent and small thickness due to pre-Arenigian erosion. The largest thicknesses, exceeding $30 \mathrm{~m}$, occur offshore to the north of Żarnowiec (Fig. 5). The lithostratigraphic equivalents of this formation in Bornholm, Scania and Öland are Lower Tremadocian bituminous mudstones, referred to the Dictyonema Shale and described also by Szymański (1984) from a small area in the northern part of the Podlasie Depression. This rock interval is the basic petroleum source rock in the Baltic Basin (Kosakowski et al., 2017). The maximum thicknesses of the interval were noted near the boreholes B21-1/95 and B16-1/85. The thickness diminishes towards the west and east. Onshore, the thickness is much smaller and reaches from 10 to $15 \mathrm{~m}$ near Łeba and Żarnowiec, to diminish towards the south and east

Sasino Mudstone Formation. This formation earlier distinguished as the Sasino Claystone Formation (Modliński and Szymański, 1997; Modliński and Szymański, 2008), the Udal Formation in the Lublin area, the Cieszanów Formation in the Biłgoraj-Narol Zone (Modliński, 1984; Modliński and Szymański, 2005) and at present unified in the Sasino Formation (Porębski and Podhalańska, 2019) is the next lithostratigraphic unit, composed of shales of Darriwilian and Early Katian age (Upper Llanvirn and Caradoc). This is the only Ordovician black shale unit widely distributed in all basin-like structural units on the EEC in Poland. The rocks include black mudstones, often with pyrite, dark grey, bituminous, locally calcareous, silicified, in the middle part commonly paler, grey-green and bioturbated. Tuffite and bentonite interbeds and laminae occur within the mudstones. The Sasino Formation contains frequent graptolites, with subordinate benthic fauna. The graptolite assemblages identified in the unit indicates that in the western part of the basin (e.g., Kościerzyna IG 1 borehole), in its maximum range the Sasino Formation encompasses the Upper Darriwilian, Sandbian and Lower Katian (Llanvirn to uppermost Caradoc), i.e. from the Didymograptus murchisoni to the Climacograptus styloideus (= Pleurograptus linearis) graptolite biozones. The thickness of the formation reaches $\sim 35 \mathrm{~m}$ in onshore successions and $\sim 70 \mathrm{~m}$ in offshore successions of the Baltic Depression (Fig. 6). The Sasino Formation is one of the most prospective units for unconventional hydrocarbon accumulations in shales in the study area (Podhalańska et al., 2016b). The facies development of this unit is variable. Its lower and upper parts are darker in colour, enriched in organic matter; while its middle part is distinctly lighter coloured, bioturbated, with a lower content of dispersed organic matter.

The Sasino Formation occurs in the western part of the Podlasie Depression and in the Lublin area. Its age corresponds here to the latest Sandbian and Early Katian (Late Caradoc).

Jantar Mudstone Formation. The oldest Silurian shale unit, can be distinguished along the western margin of the EEC and in the Biłgoraj-Narol Zone. It is separated from the underlying Sasino Formation by Upper Ordovician carbonate-marl deposits, the Prabuty Formation in the western part of the Baltic Depression and its equivalents in the eastern part of the Baltic, Podlasie and Lublin regions (Fig. 4).

The Jantar Mudstone Formation (Porębski and Podhalańska, 2019), earlier distinguished as the Jantar Bituminous Black Claystone Member (Modliński et al., 2006), is developed as black bituminous mudstones with a graptolite fauna. The formation represents transgressive deposits passing into highstand strata in a transgressive-regressive (T-R) cycle. Its thickness is variable, the largest being in the Baltic part of the EEC margin, where it exceeds $25 \mathrm{~m}$ (Fig. 7). In the Podlasie Depression and Lublin areas, the thickness of the Jantar Formation is from 0 to several metres. Graptolites determine the age of this unit mostly as Rhuddanian-Aeronian. In some boreholes, e.g. Lębork IG 1 , and Łeba 8 on the Łeba Elevation, sedimentation of dark mudstones with graptolites began earlier, in the Hirnantian Glyptograptus persculptus Biozone, whereas in other sites the $\mathrm{O} / \mathrm{S}$ boundary is erosive with evidence of condensation (Podhalańska, 2009). A typical succession with an erosive Ordovician/Silurian boundary is in the Kościerzyna IG 1 borehole, where the boundary is pyritized. Lower Llandovery strata developed as black shales occur also in the western part of the Podlasie Depression and western part of the Lublin Basin and in the Biłgoraj-Narol Zone.

Notably, thin layers of mudstones enriched in organic matter occur also in the eastern part of the basin as a thin unit which begins the Silurian sedimentation in this area or within younger shallow-marine deposits of the Upper Llandovery (Telychian). According to geochemical analysis of organic matter (RockEval analysis), they attain elevated TOC values.

Pelplin Mudstone Formation. Deposits of the subsequent, organic-enriched Pelplin Mudstone Formation extend across almost the entire area of the Polish Baltic, Podlasie and Lublin areas. The formation reaches $\sim 400 \mathrm{~m}$ in thickness (Żarnowiec IG 1 and Prabuty IG 1 boreholes). 


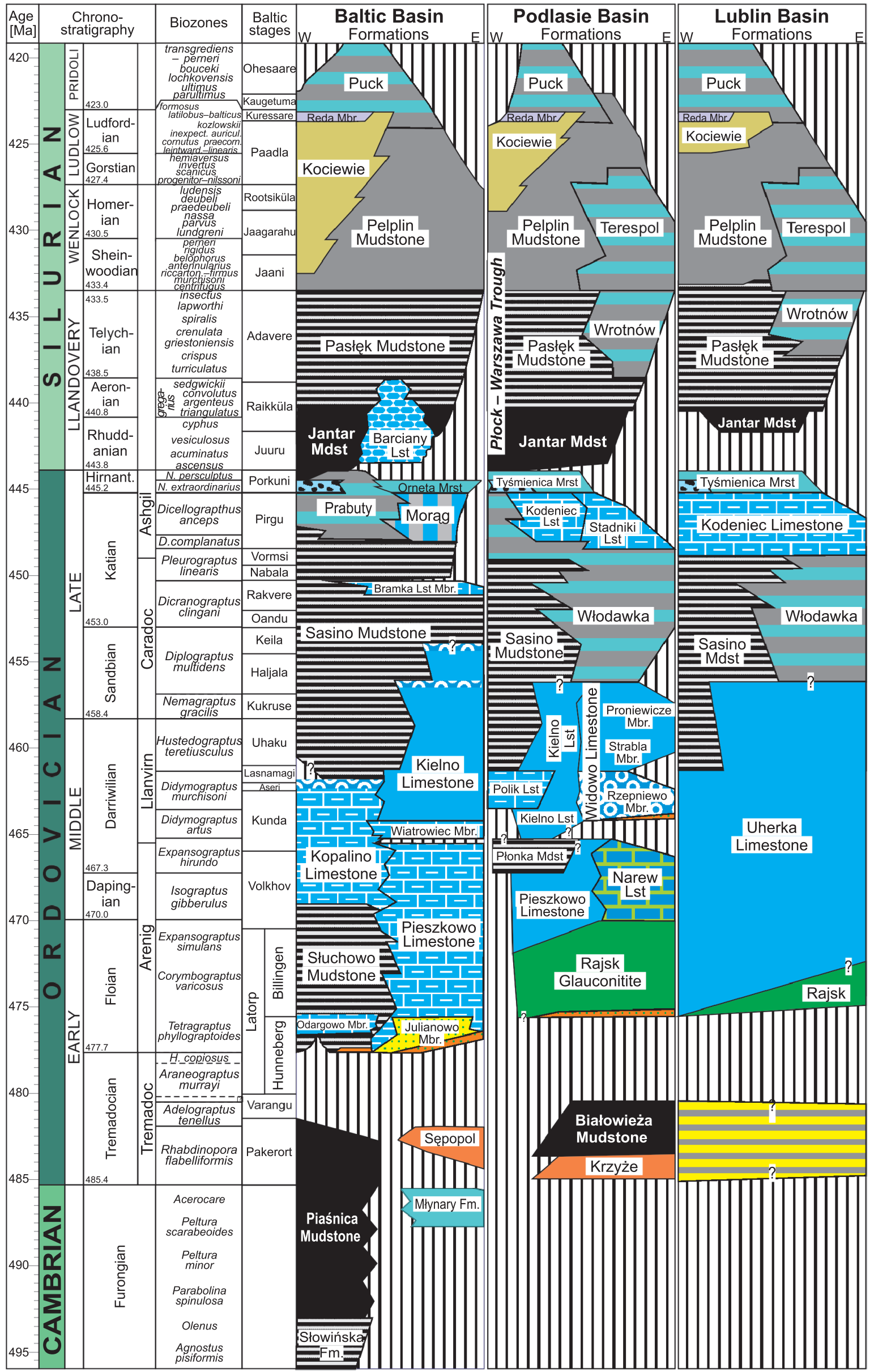




\begin{tabular}{|c|c|c|c|c|}
\hline & conglomerates, sandstones & $\begin{array}{l}\text { black organic-rich and green, organic-poor } \\
\text { mudstones, bentonites, calcareous concretions }\end{array}$ & $\prod_{\text {marly limestones, marls, }}^{\text {mudstones }}$ & glauconitite \\
\hline & sandstones, conglomerates & black organic-rich mudstones & marly and bioclastic limestones & hiatus \\
\hline & glauconitic sandstones & $\begin{array}{l}\text { calcareous mudstones, marls, } \\
\text { clayey mudstones }\end{array}$ & nodular limestones & \\
\hline 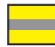 & sandstones, mudstones & marls, calcareous mudstones & $\begin{array}{l}\text { bioclastic, marly and dolomitic } \\
\text { limestones, nodular limestones }\end{array}$ & \\
\hline & mudstones, siltstones, sandstones & marly diamictites, muddy sandstones & oolitic limestones & \\
\hline & $\begin{array}{l}\text { dark mudstones, bentonites, bioclastic } \\
\text { limestones, calcareous concretions }\end{array}$ & calcisiltites, calcareous mudstones & $\begin{array}{l}\text { glauconitic limestones, marly and } \\
\text { bioclastic limestones }\end{array}$ & \\
\hline
\end{tabular}

Fig. 4. Lithostratigraphic subdivision of the Upper Cambrian, Ordovician and Silurian succession of the East European Craton (from Porębski and Podhalańska, 2019, completed)

Ordovician-Silurian chronostratigraphy, graptolite zonation and correlation of the Ordovician and Silurian standard stages to the Baltic regional stages after Cooper et al. (2012) and Melchin et al. (2012); the standard graptolite zonation is modified to include the local zones of Urbanek and Teller (1997) and Porębska et al. (2004); Hirnant. - Hirnantian; Lst - limestone; Mdst - mudstone; Mrst - marlstone, Mbr. member

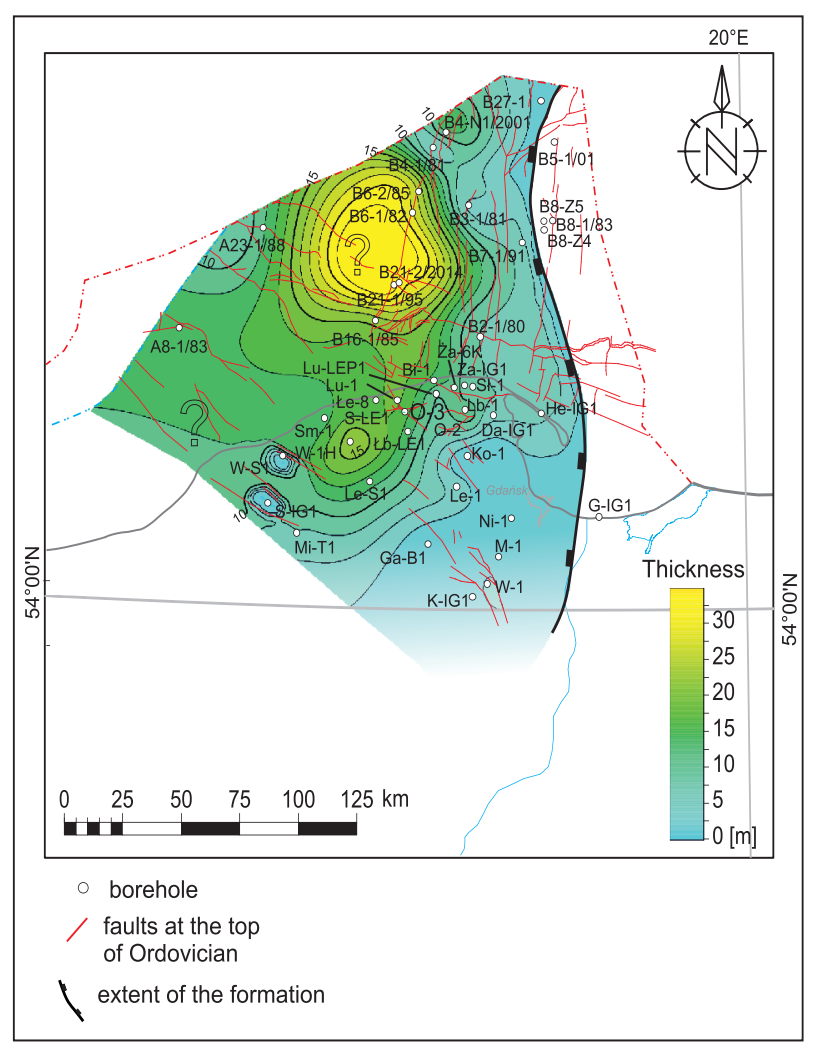

Fig. 5. Thickness map of the Piaśnica Formation

Białogóra 1 - Bi-1, Borcz 1 - B-1, Darżlubie IG 1 - Da-IG1, Gapowo B1-Ga-B1, Gdańsk IG 1 - G-IG1, Hel IG 1 - He-IG1, Kochanowo 1 - Ko-1, Kościerzyna IG 1 - K-IG1, Lewino-1 - Le-1, Lubiny 1 - Lu-1, Lublewo LEP 1 - Lu-LEP1, Lubocino 1 - Lb-1, Łeba 8 - Łe-8, Miszewo T-1 - Mi-T1, Niestępowo 1 - Ni-1, Opalino 2-O-2, Opalino 3 - O-3, Sławoszyno LEP1 - Sł-1, Słupsk IG 1 - S-IG1, Smołdzino 1 - Sm-1, Strzeszewo LE-1 - S-LE1, Warblino 1H - W-1H, Wysin 1 W-1, Wytowno S1 - W-S1, Żarnowiec 6K - Ża-6K, Żarnowiec IG 1 Ża-IG1

The stratigraphic range of the formation and its thickness change from west to east: in the Kościerzyna IG 1 borehole it represents the Lower Wenlock (upper boundary below the Gothograptus nassa Biozone), in the Gdańsk IG 1 borehole it encompasses the entire Wenlock and Gorstian (Lower Ludlow), and in the Żarnowiec IG 1 borehole it ranges from the lowermost Wenlock to the Ludfordian Bohemograptus praecornutus Biozone.

The lower part of the Pelplin Formation is considered prospective, developed mainly as grey and dark grey mudstones/claystones, with a graptolite fauna, and usually corresponding to the base of Sheinwoodian Cyrtograptus Iundgreni Biozone. The upper part of the Pelplin Formation is represented by grey and greenish mudstones with limestone nodules and intercalations including a smaller content of non-oxidized organic matter; its prospective potential is much lower.

\section{METHODOLOGY}

Various study methods, i.e. stratigraphic, sedimentological, geophysical, geochemical, petrophysical and geomechanical, conducted on data from the boreholes shown in Figure 2 were used to determine the ranges of prospective zones and their characteristics. More than 4000 laboratory analyses on rock samples from several dozen archival boreholes have been applied. They include: mineral/petrography analyses (optical microscope and SEM observations, XRD analyses, fluid inclusion observations), organic geochemistry (TOC analyses, organic matter thermal maturity analyses, kerogen analyses) and petrophysical analyses (porosity, permeability). The petrophysical analyses as well as the quantitative determinations of organic matter, porosity and mineral composition calculated from geophysical logs, from 21 archival boreholes, have been made by the Oil and Gas Institute - National Research Institute in Kraków. The detailed results of the laboratory analyses and their interpretation as well as stratigraphic, sedimentological and geophysical interpretations are presented in several papers and reports (Dyrka, 2016; Feldman-Olszewska and Roszkowska-Remin, 2016; Gąsior et al., 2016; Grotek, 2016; Karcz and Janas, 2016; Nowak, 2016; Podhalańska et al., 2016a, b, c, 2018; Roman, 2016; Sikorska-Jaworowska et al., 2016).

\section{STRATIGRAPHY}

The results of borehole logging, based on which rock successions corresponding to particular lithostratigraphic formations were distinguished, were analysed. Lithostratigraphic units were defined based on gamma-ray log (GR), neutron porosity (NPHI), bulk density (RHOB), and in some cases acoustic $\mathrm{P}$-wave velocity log $(\mathrm{Vp})$ and resistivity log (Rt) information. 


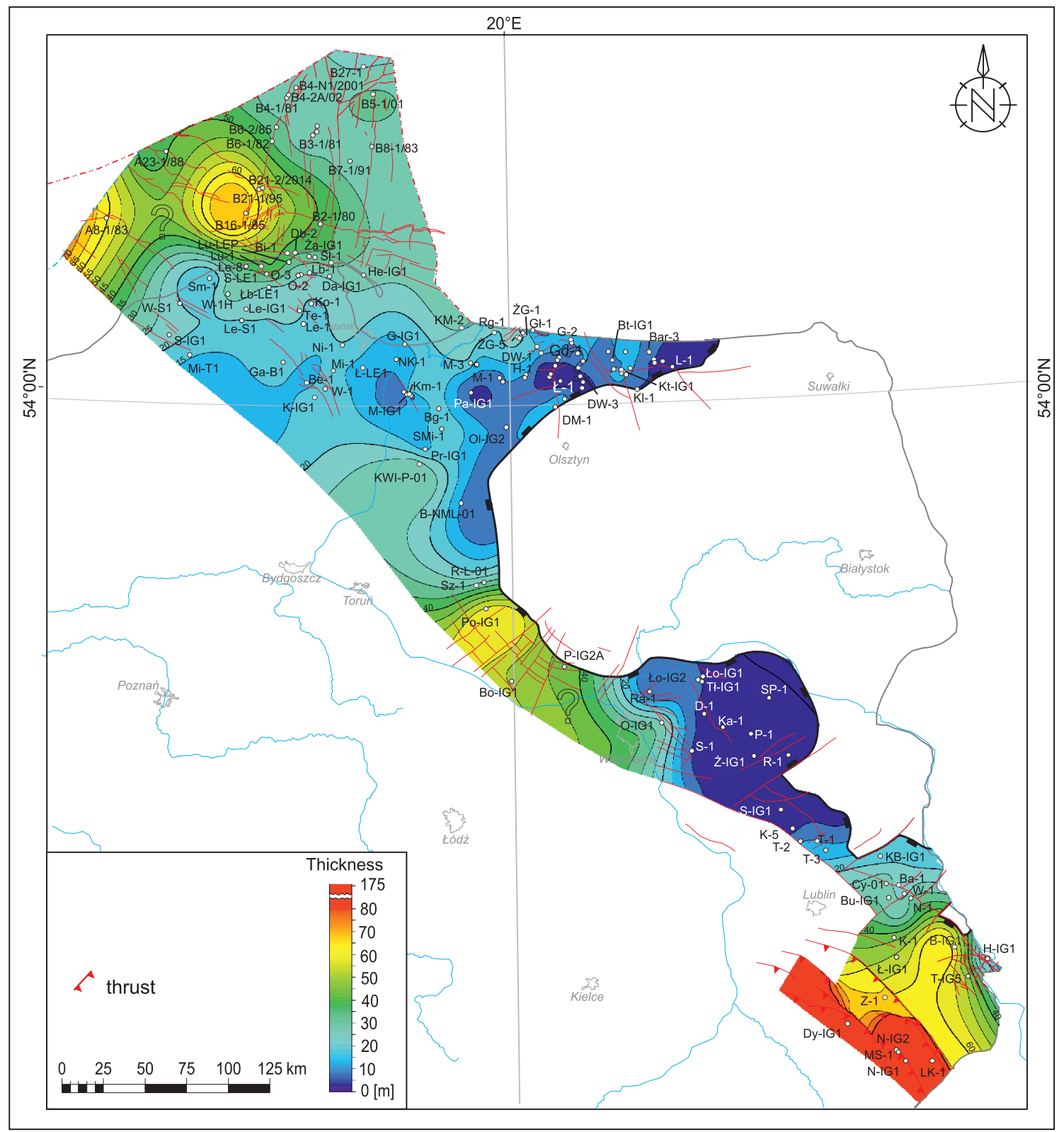

Fig. 6. Thickness map of the Sasino Formation

Bachus 1 - Ba-1, Barciany 3 - Bar-3, Bartoszyce IG 1 - Bt-IG1, Bagart-1 - Bg-1, Białopole IG 1 - B-IG1, Będomin 1 Be-1, Bodzanów IG 1 - Bo-IG1, BRO-NM Lubawskie-01 - B-NML-01, Busówno IG 1 - Bu-IG1, ORZ Cyców 01 - Cy-01, Debki 2 - Db-2, Debowiec Warmiński 1 - DW-1, Debowiec Warmiński 3 - DW-3, Dobre 1 - D-1, Dobre Miasto 1 - DM-1, Dyle IG 1 - Dy-IG1, Gałajny 2 - G-2, Glądy 1 - Gd-1, Głębock 1 - Gł-1, Henrykowo1 - H-1, Horodło IG 1 - H-IG5, Kałuszyn 1 - Ka-1, Kamionka 1-Km-1, Klewno 1-KI-1, Krowie Bagno IG 1 - KB-IG1, Krupe 1-K-1, Krynica Morska 2 KM-2, Kock 5 - K-5, KWI Prabuty 01 - KWI-P-01, Lubycza Królewska - LK-1, Lesieniec 1 - L-1, Lębork IG 1 - Le-IG1, Lębork S-1 - Le-S1, Łaniewo 1 - Ł-1, Łebień Le 1 - Łb-LE1, Łęgowo LE-1 - Ł-LE1, Łochów IG 1 - Ło-IG1, Łochów IG 2 Ło-IG2, Łopiennik IG 1 - Ł-IG1, Majdan Sopocki1 - MS-1, Malbork IG 1 - M-IG1, Miłowo 1 - Mi-1, Młynary 1 - M-1, Młynary 3 - M-3, Narol IG 1 - N-IG1, Narol PIG 2 - N-IG2, Nowa Kościelnica 1 - NK-1, Niwa 1 - N-1, Okuniew IG 1 O-IG1, Olsztyn IG 2 - OI-IG2, Pasłęk IG 1 - Pa-IG1, Płońsk IG2A - P-IG2A, Polaki 1 - P-1, Polik IG 1 - Po-IG1, Prabuty IG 1 - Pr-IG1, Radzymin 1 - Ra-1, Rogity 1 - Rg-1, Rówce 1 - R-1, RYP-Lutocin-01 - R-L-01, Siedliska IG 1 - S-IG1, Siennica 1 - S-1, Sokołów Podlaski 1 - SP-1, Stare Miasto 1 - SM-1, Szczawno 1 - Sz-1, Tarkawica 1 - T-1, Tarkawica 2 - T-2, Tarkawica 3 - T-3, Terebin IG 5 - T-IG5, Tępcz 1 - Te-1, Tłuszcz IG 1 - Tł-IG1, Zwierzyniec 1 - Z-1, Żebrak IG 1 Ż-IG1, Żelazna Góra 1 - ŻG-1, Żelazna Góra 5 - ŻG-5; other explanations as on Figure 5

When available, the stratigraphy and depths of boundaries between lithostratigraphic units were distinguished based on the description and analysis of borehole cores. After selection of boreholes and depth intervals, the core sections were measured to describe rock successions, and to determine and constrain the chronostratigraphic levels based mainly on the graptolite biostratigraphy. The stratigraphy and depth ranges of the lithostratigraphic formations and prospective zones were determined and checked.
Graptolites, which are frequent in the samples, are the basis of the biostratigraphic zonations of the Ordovician and Silurian systems. That for the Silurian in Poland corresponds to the traditional zonation described in classical exposures in England and Wales. With modifications, this is applied today as the Generalized Graptolite Zonation (GGZ), established by the Subcommission for the Stratigraphy of the Silurian System (Koren et al., 1996). The chronostratigraphic scheme for the Silurian according to Melchin et al. (2012) is based on the biostrati- 


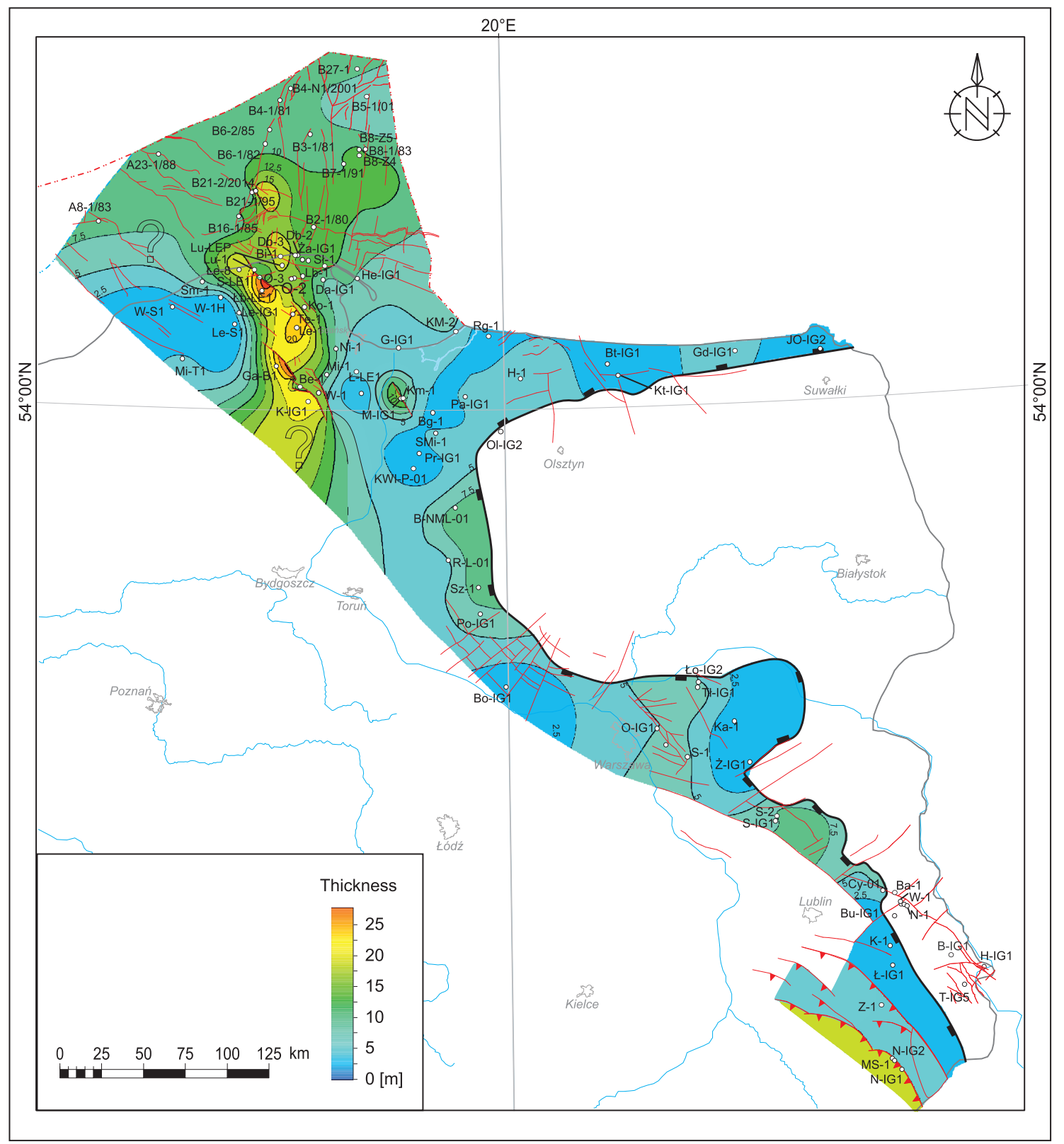

Fig. 7. Thickness map of the Jantar Formation

Abbreviations of boreholes not cited on Figures 5 and 6: Dębki 3 - Db-3, Gołdap IG 1 - Gd-IG1, Jezioro Okragłe IG 2 - JO-IG2, Siedliska 2 - S-2; other explanations as on Figures 5 and 6

graphic subdivision by Koren et al. (1996) taking into account the graptolite zonation for the Wenlock, Ludlow and Pridoli presented by Urbanek and Teller (1997). Taxonomic determinations and biostratigraphy of the Silurian by Tomczyk (1990), Porębska et al. (2004) and Podhalańska (2019) were applied in the biostratigraphic analysis.

Stratigraphic units of the Ordovician and Silurian and their boundaries were determined based on the lithostratigraphic scheme for the facies zones of the Baltic-Podlasie-Lublin Basin (Modliński, 1984; Modliński and Szymański, 1997, 2008; Szymański and Modliński, 2003; Modliński et al., 2006; Podhalańska et al., 2010). Figure 4 shows the latest lithostratigraphic subdivision for the Ordovician and Silurian of the EEC area in Poland (Porębski and Podhalańska, 2019).

\section{LITHOLOGY, SEDIMENTOLOGY AND FACIES ANALYSIS}

The facies analysis included lithological-sedimentological logging of selected (considered as potentially prospective) rock successions in boreholes thought to be the most representative regarding lithological variability in the study area. The logging was made on a centimetre scale and included the following variables: lithology, grain size, presence and types of sedimentary structures, degree of bioturbation, colour, carbonate content, macrofaunal content, state of preservation and mode of occurrence, texture, presence of veins, and tectonic deformation.

Lithofacies characteristics of selected rock successions were based on the variability of these parameters. They were 
assembled in lithofacies associations which, according to the authors, best characterize the prospective Ordovician and Silurian lithostratigraphic formations. Full characteristics of lithofacies were provided in Feldman-Olszewska and Roszkowska-Remin (2016).

\section{ORGANIC MATTER GEOCHEMISTRY, PETROLOGY AND THERMAL MATURITY}

Geochemical analysis of organic matter pyrolytic methods coupled with organic matter petrological and thermal maturity studies, as well as archival data and data from newly drilled boreholes (results of Rock-Eval - R-E, LECO and similar methods: Source Rock Analyzer - SRA, TOC analyzer, S1-S2 analyzer), were used to create regional maps of the Total Organic Carbon content (TOC), Oil Saturation Index (OSI), and maps of organic matter thermal maturity shown as Vitrinite Reflectance Equivalent (VRE) values from optical microscopy studies and pyrolytic analyses $\left(T_{\max }\right)$. Other R-E parameters, including free hydrocarbon content (S1), hydrocarbon generation potential (S2), hydrogen index $(\mathrm{HI})$ and oxygen index $(\mathrm{OI})$, were also analysed in terms of source rock quality and shale formational prospectivity but do not constitute the main criteria and therefore are not the subject of this paper. The pyrolytic $\mathrm{R}-\mathrm{E}$ method is the most common of the preliminary geochemical source rock evaluation methods. It is used to determine the hydrocarbon potential, type of kerogen occurring in the rocks, and thermal maturity (e.g., Espitalié et al., 1985; Behar et al., 2001). Large number of R-E analyses (Janas, 2016, 2018; Karcz, 2016; Karcz and Janas, 2016) and dispersed organic matter microscopy studies (Grotek, 2016) have been performed.

To create generalized regional maps of particular parameters, based on which the ranges of prospective zones were determined, median values of particular parameters representing each of the prospective formations were calculated. The OSI, which is an indication of thermal maturity, but also a measure of the indirect oil content index (also known as NOC normalized oil content), is interpreted as a function of parameter S1 from the R-E pyrolytic analysis and TOC (Jarvie and Baker, 1984):

$$
\mathrm{OSI}=100 \times \mathrm{S} 1 / \mathrm{TOC}
$$

Due to the lack of vitrinite macerals in Lower Paleozoic rocks, the results of reflectivity of solid bitumen (BRo) were recalculated into VRE according to the formula of Jacob (1989):

$$
\operatorname{VRE}=0.618 \times(\mathrm{BRo})+0.4
$$

whilst the results of reflectivity of graptolites and other vitrinite-like particles (Rvitr-like) were recalculated to VRE according to the formula suggested by Makos et al. (2016):

$$
\operatorname{VRE}=0.71 \times(\text { Rvitr-like })+0.19
$$

Detailed methodologies applied in the geochemical and petrological investigations of organic matter have been provided by Grotek (2016), Karcz and Janas (2016), Janas (2018) and Klimuszko (2018).

\section{AVERAGE TOTAL GAS CONTENT BASED ON DESORBED GAS ANALYSIS}

Core desorption is a method of measuring the sorbed gas content in coals (coal bed methane; CBM) and shales (desorbed gas), which is recalculated to a mass unit. The measurement of desorbed gas takes place in standard conditions, determined at $15.6^{\circ} \mathrm{C}$ and $1013 \mathrm{hPa}$. By the time the core is cut appropriately and inserted in an isolated measurement tank at the surface, the gas is released from the pore space during the lifting of the core from the wellbore to the surface. The volume of gas released from the rock prior to inserting the core in the tank (lost gas) should be estimated based on accepted chemical and physical assumptions. Part of the gas is still present in the unconnected pore space known as the residual gas; its measurement is made by crushing the rock. The sum of the measured desorbed and residual gas, and the estimated lost gas, is the assumed total gas saturating the core. Studies of desorbed and residual gas, as well as estimations of lost and total gas were performed in shale oil and gas exploration boreholes in Poland by Geokrak company (Kraków). The calculated total gas (in $\mathrm{m}^{3} / \mathrm{t}$ ) was used to determine the extents of the prospective zones based on objective criteria (Table 1).

\section{PETROPHYSICS}

The project utilized the results of petrophysical analyses (total porosity, effective porosity, open porosity, and porosity saturated with gas) performed in boreholes by different laboratories (e.g., the Oil and Gas Institute-NRI, Core Laboratories, TerraTek etc.) and by application of various, not always comparable, methods. That caused problems with direct correlation and integration of the results obtained. However, taking into account the reservoir quality significance of these parameters, the data were assembled within one database and considered as point data. When possible, median values of particular parameters were calculated for each prospective zone. Quantitative determinations of the petrophysical properties were also obtained by study of the borehole logs.

\section{BRITTLENESS AND CLAY CONTENT}

Brittleness is a parameter commonly used in mineralogical and geomechanical analysis to describe the force needed to fracture the rock in particular load conditions, in petroleum unconventional play studies to characterize parts more or less prone to hydraulic fracturing and to define horizontal borehole location based on the distinction of units with the highest tendency to failure under applied stress. Typically, brittleness is represented by the Brittleness Index (BI). Despite numerous studies concerning the standard definition of $\mathrm{BI}$, there is still no generally accepted equation and appropriate standard for assessing this parameter, mostly due to a variety of factors that affect mechanical properties in a heterogeneous reservoir with variable mineralogical composition, diagenetic pathways and diverse tectonic activity. $\mathrm{BI}$ can be determined by laboratory stress-strain measurements, elastic properties and mineralogical composition. Based on available data and previous mineralogical analyses of Ordovician and Silurian shales from the Baltic Basin (Pachytel et al., 2017; Cyz et al., 2018), we have decided to use the modified formula of Kias et al., (2015) to determine the Brittleness Index $\left(\mathrm{Bl}_{\mathrm{BB}}\right)$ as a measure of shale brittleness:

$\mathrm{Bl}_{\mathrm{BB}}=\frac{\mathrm{V}_{\text {QFP }}+V_{\text {carbonate }}+V_{\text {sulphate }}+V_{\text {sulphide }}+V_{\text {phosphate }}+V_{\text {oxide }}}{V_{\text {QFP }}+V_{\text {carbonate }}+V_{\text {sulphate }}+V_{\text {silphide }}+V_{\text {phosphate }}+V_{\text {oxide }}+V_{\text {clay }}+V_{\text {TOC }}}$ 
Criteria for assessing the potential occurrence of oil and gas accumulations in shale formations (after Wójcicki et al., 2017)

\begin{tabular}{|l|c|c|c|c|c|c|c|c|}
\hline Criterion & VRE & $\begin{array}{c}\text { TOC } \\
{[\% \text { by weight] }}\end{array}$ & $\begin{array}{c}\text { Effective } \\
\text { thickness }\end{array}$ & $\begin{array}{c}\text { Porosity } \\
\text { filled with } \\
\text { hydrocarbons }\end{array}$ & $\begin{array}{c}\text { Brittleness } \\
\text { (quartz, feldspars } \\
\text { and carbonates) }\end{array}$ & $\begin{array}{c}\text { Average total } \\
\text { gas content }\end{array}$ & OsI & $\begin{array}{c}\text { Reservoir } \\
\text { pressure }\end{array}$ \\
\hline Unit & {$[\%]$} & {$[\%]$} & {$[\mathrm{m}]$} & {$[\%]$} & {$[\%]$} & {$\left[\mathrm{m}^{3} / \mathrm{t}\right]$} & & \\
\hline $\begin{array}{l}\text { Optimal } \\
\text { value }\end{array}$ & - & $>2$ & $>15$ & $>2$ & $>=65$ & $>=1.5$ & $>100$ & $\begin{array}{c}\text { above hydrostatic } \\
\text { pressure }\end{array}$ \\
\hline $\begin{array}{l}\text { Boundary } \\
\text { value }\end{array}$ & $>=06$ and $<3.5$ & $>1.5$ & $>=10$ & - & $>=40$ & $>=0.5$ & $>50$ & - \\
\hline
\end{tabular}

Average total gas content - based on desorbed gas analysis

The Regulation of the Ministry of the Environment on the geological and investment documentation of hydrocarbon deposits (1st July 2015; Polish Journal of Laws, 2015) establishes the minimum silica content $-10 \%$ of quartz - as a measure of brittleness both in the case of gas-bearing shales and sands. It also specifies the maximum clay content at $60 \%$. The reports of the British Geological Survey (Andrews, 2013, 2014) recommend the minimum volume of silicates (excluding phyllosilicates) as $>30 \%$. This includes the volume content of quartz and feldspar/plagioclase in shale (Jarvie, 2008; EIA, 2013). The optimal criterion (not the boundary one) is a maximum clay content defined as $35 \%$. This is rather the border between reservoirs of good and poor quality than the extraction limit. However, the most important factor is the total content of all brittle elements, which determines the susceptibility to fracturing. Therefore, the limit extraction value was assumed as $\mathrm{BI}=0.4$. Where the ductility is higher $(\mathrm{BI}<0.4)$, the propagating fracture can be more easily arrested and stopped. That phenomenon results in a smaller Stimulated Reservoir Volume and hence smaller production rates.

The $\mathrm{BI}_{\mathrm{BB}}$ was calculated based on powder X-ray diffraction analyses made for 60 exploration boreholes located in the Baltic, Podlasie and Lublin regions. Five shale formations, Pelplin, Pasłęk, Jantar, Sasino, and Piaśnica, as well as the carbonate Prabuty Formation were investigated during the measurements. The full study consists of measurements from 2,064 laboratory samples acquired from borehole reports. The results were analysed taking into account borehole location within the basin, sampling depth, formation heterogeneity, and carbonate or tuffite intercalations. Particular attention was also paid to the presence or absence of a regular sampling step; some of the companies had a constant sampling step, whereas others chose the most prospective intervals for sampling.

\section{GEOMECHANICS}

Geomechanical properties of rocks are important for determining the susceptibility of shale to the propagation of hydraulic fractures and the direction of their development. Detection of geomechanically prospective zones was based mainly on the Young's modulus (YM), the Poisson ratio (PR) and the stress magnitudes (hence, the stress regime). The YM and PR determine the mechanical reaction of rocks to deformation. Such deformation may increase the number of fractures and reservoir productivity or decrease fracture permeability. At the high pressures prevailing in reservoir conditions, a high YM helps to maintain the fracture aperture and reduce the embedment phenomenon. The Young's modulus was calculated during Uniax- ial Compressive Strength, Triaxial Compressive Strength and Tensile Strength tests (Farzin et al., 1975; Ulusay and Hudson, 2007), correlated afterwards with borehole logs.

In the case of the boreholes studied all possible data obtained from borehole reports were collected and studied. The oil companies performed different geomechanical analyses using different methods, dissimilar tools and in divergent conditions. Such measurements often preclude the possibility to compare the values calculated and draw conclusions at a reservoir scale; nevertheless, all data that could be collected and compared were used in the analyses.

\section{DESCRIPTION OF PROSPECTION CRITERIA}

The general (boundary) criteria defining unconventional hydrocarbon reservoirs are given in the latest Regulation of the Minister of the Environment (Polish Journal of Laws, 2015: 968). However, these criteria refer to documented hydrocarbon reservoirs, which so far have not been recorded in Poland, in the cases of either shale gas, shale oil, or tight gas. In this case, the term refers rather to prospective zones for potentially productive shale oil and gas accumulations, and not to reservoirs. Moreover, there are no production data available; in the best cases only the results of production tests are available. Borehole data are presently inadequate and insufficiently reliable for their application in the definition of reservoir criteria.

Parameters describing source rock generative potential, type of hydrocarbon generated and level of thermal maturation, used to determinate prospective zones, are shown in Tables 2-4.

Therefore, the criteria accepted follow those provided in the most recent PGI-NRI report (Wójcicki et al., 2017), accepted by the Ministry of Environment, focused on the Lower Paleozoic

Table 2

Semiquantitative source richness interpretation of TOC (Peters, 1986; Dembicki, 2017)

\begin{tabular}{|c|c|}
\hline Quantity & $\begin{array}{c}\text { TOC } \\
{[\text { wt. } \%]}\end{array}$ \\
\hline Poor & $0.0-0.5$ \\
\hline Fair & $0.5-1.0$ \\
\hline Good & $1.0-2.0$ \\
\hline Very good & $>2.0$ \\
\hline
\end{tabular}


$T_{\max }$ and VRE describing the level of thermal maturation of organic matter (i.a., Tissot and Welte, 1984; Ruble et al., 2012)

\begin{tabular}{|l|c|c|}
\hline \multicolumn{1}{|c|}{ Thermal maturation } & $T_{\max }\left[{ }^{\circ} \mathrm{C}\right]$ & VRE [\%] \\
\hline Immature & $<\sim 430$ & $<0.6$ \\
\hline Oil window & $\sim 430-455$ & $>=0.6<=1.1$ \\
\hline Wet gas window & $\sim 455-475$ & $>1.1<=1.4$ \\
\hline Dry gas window & $>\sim 475$ & $>1.4<=2.0$ \\
\hline $\begin{array}{l}\text { ?Overmature/upper dry gas } \\
\text { preservation limit }\end{array}$ & $\begin{array}{c}\text { value unknown due to low } T_{\max } \text { reliability for a very highly thermally } \\
\text { maturated organic matter (especially refers to type II kerogen) }\end{array}$ & $>2.0 / 3.5$ \\
\hline
\end{tabular}

Ta ble 4

Oil saturation index, also known as NOC (normalized oil content; Jarvie and Baker, 1984)

\begin{tabular}{|l|c|}
\hline & $\begin{array}{r}\text { OSI } \\
{[\mathrm{mg} / \mathrm{H} \text { TOC] }}\end{array}$ \\
\hline Low thermal maturity source rock or expelled hydrocarbons & $0-25$ \\
\hline Early thermally mature source rock & $25-50$ \\
\hline Thermally mature, stained source rock & $50-100$ \\
\hline High HC saturation allowing its extraction or core contamination with oil-based drilling mud & $>100$ \\
\hline
\end{tabular}

shales in the Baltic-Podlasie-Lublin Basin and the Biłgoraj-Narol Zone. Some of the reservoir criteria provided in the Regulation from 1st July 2015 (boundary criteria) have been used there, resulting from the experience gathered during shale oil and gas prospection and exploitation in American shale oil and gas basins (optimal criteria), as well as from literature data (Jarvie, 2012; PIG-PIB, 2012; Andrews, 2013, 2014; EIA, 2013; Michael et al., 2014). These criteria have been summarized in Table 1. Notably, the relationships between their values and the possibility of technological hydrocarbon exploitation from shale successions are not always precise; in many cases the mutual relationships between the analysed parameters are equally important.

The following ranges of the thermal maturity of organic matter, characterizing the presence of various types of hydrocarbon have been accepted: $0.6 \%>=\mathrm{VRE}<=1.1 \%$ for oil, $1.1 \%>$ VRE < $=1.4 \%$ for wet gas, $1.4 \%>$ VRE < $=2.0 \%$ for dry gas windows and the ?overmature/upper dry gas theoretical preservation limit (VRE $>2.0 / 3.5 \%$ ).

\section{RESULTS \\ CHARACTERISTICS OF THE PROSPECTIVE ZONES}

Based on the laboratory analyses conducted as well as on the interpretation of all data from the documentation of archival and newly drilled boreholes, four zones (PZ1 to PZ4) fulfilling prospective criteria (Tables 1-4) have been distinguished within prospective Cambrian, Ordovician and Silurian formations of the Baltic-Podlasie-Lublin Basin.

\section{CHARACTERISTICS OF PZ1}

\section{STRATIGRAPHY, LITHOLOGY AND LITHOFACIES}

Prospective zone 1 (PZ1) was distinguished in the northern part of the Łeba Elevation and extends mainly in the offshore area to the boundary of the Polish Economic Zone on the Baltic
Sea and in an onshore zone with a much smaller surface area (Fig. 8). The zone encompasses Furongian strata and largely corresponds to the extent of the Piaśnica Formation with the exception of the southern area, where the zone does not fulfil the prospective criteria (thickness $>10 \mathrm{~m}$ and TOC $>1.5 \mathrm{wt} . \%$ ). The criteria are fulfilled in the onshore area of the northern part of the Łeba Elevation. The thicknesses of PZ1 correspond to the recognized thickness maximum of the Piaśnica Formation (Fig. 5), reaching to $35 \mathrm{~m}$ in borehole B21-1/95 and B21-2/2014, $30.5 \mathrm{~m}$ in borehole B16-1/82 located offshore to the north of boreholes Lubiny 1, Białogóra 1, Łeba 8, Opalino 2 and Opalino 3. PZ1 comprises characteristic black bituminous shales with a very high content of organic matter, deposited in the deeper parts of a poorly oxygenated basin in reducing conditions both in the lowest part of the water column and in bottom sediment. Limestone interbeds and intercalations have been noted. The thickness of PZ1 decreases onshore to the south (Fig. 9).

\section{GEOCHEMISTRY AND THERMAL MATURITY} OF ORGANIC MATTER

The extent of PZ1 is slightly modified with regard to the extent stated in the first stage of the project (Podhalańska et al., 2016a, b). The largest change in the PZ1 extent refers to the Warblino area where Furongian-Tremadocian deposits exceed $20 \mathrm{~m}$ in thickness and fulfil the boundary criteria of hydrocarbon saturation (Fig. 8).

The Piaśnica Formation is the main source rock in the Lower Paleozoic petroleum system of the Baltic Basin (Kotarba, 2010; Więcław et al., 2010a, b). Application of data from newly drilled boreholes and supplementation of the R-E database together with archival data sets has allowed updating of knowledge on the geochemical characteristics of the Piaśnica Formation within PZ1 (Janas, 2018; Podhalańska et al., 2018). The TOC content, which is one of the most significant prospectivity parameter for shale oil and gas formations, reaches 5 to 12 wt.\% which indicates very good source rock quality (Table 2). The highest TOC values have been noted near the B6 and B21 oil and gas fields in the Baltic Sea, near Białogóra, Dębki, Żarnowiec and along the Łeba-Warblino-Lębork-Miszewo area 


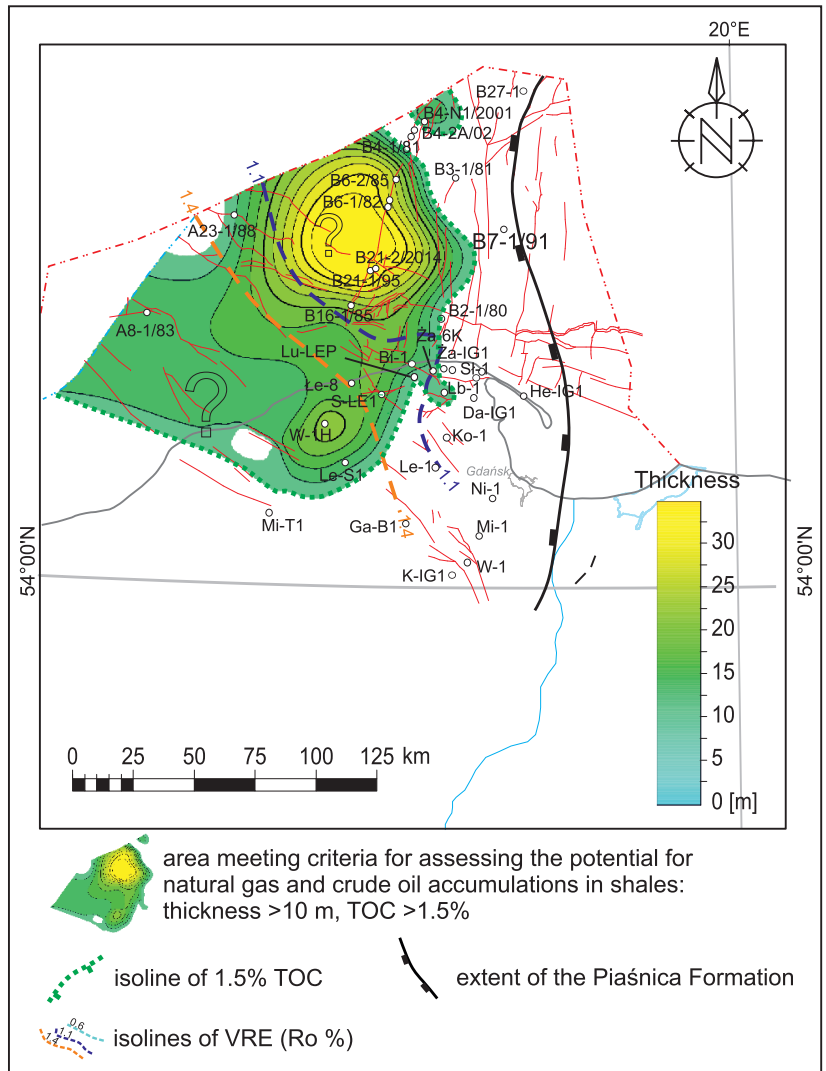

Fig. 8. PZ1 map

Other explanations on Figures 5 and 6

(Fig. 10). OSI ranges from $<10$ to $60 \mathrm{mg} \mathrm{HC} / \mathrm{g}$ TOC (which indicates low maturity to early mature source rocks; Table 4). The highest OSI values were noted near the Białogóra, Dębki, Żarnowiec and Lubocino areas (Fig. 11). $T_{\max }$ values are from 430 to $>500^{\circ} \mathrm{C}$, which indicates thermal maturity from the beginning of the oil window to the dry gas/?overmature window (Table 3). The Łeba Elevation is in the oil window $\left(435-445^{\circ} \mathrm{C}\right)$, whereas to the west and south-west the thermal maturity increases. This observation is generally in accordance with the values of solid bitumen reflectivity recalculated to Vitrinite Reflectivity Equivalents (0.7-1.1\% VRE; Jacob, 1989), with the exception that the southwestern part of the Łeba Elevation is in the initial phase of the wet gas window (>1.1\% VRE). Recalculated VRE values increase to the south-west and near Warblino probably indicate the dry gas window ( $>1.4 \%$ VRE).

Kerogen within rocks of the Piaśnica Formation is the oil-prone type II, composed mainly of solid bitumen, phytoclasts, and vitrinized or fusinitized trilobite remains (Grotek, 2016).

\section{AVERAGE TOTAL GAS CONTENT}

The total gas content (sum of desorbed gas, residual gas and estimated lost gas) attains median values $>1.5 \mathrm{~m}^{3} / \mathrm{t}$ near the Opalino area, $>2.5 \mathrm{~m}^{3} / \mathrm{t}$ near the $\mathrm{B} 21$ gas field, $>3.5 \mathrm{~m}^{3} / \mathrm{t}$ near the Warblino area and $>12 \mathrm{~m}^{3} / \mathrm{t}$ near the Lębork area.

\section{PETROPHYSICS}

Petrophysical data for the entire formation are summarized in Table 5. Data for porosity filled with gas are available only for one borehole (Lębork S-1) and their median values do not fulfil the optimal prospective conditions.

\section{GEOMECHANICS}

The Brittleness Index of PZ1 within the Baltic Basin visibly decreases farther from the NW Teisseyre-Tornquist Zone (TTZ), towards the NEE (Fig. 12), due to an increase in clay content. The area considered as prospective for hydrocarbon exploration is characterized by high $\mathrm{BI}$ values, from 0.5 in the eastern part to over 0.7 in the western part. The easternmost, offshore part, seems to be more ductile, consisting of high amounts of clay minerals. The PZ1 deposits analysed are susceptible to vertical fracture propagation during hydraulic fracturing treatment. The dynamic YM measured parallel to bedding in the Lebork area oscillate between 45-80 GPa with a median value of $73 \mathrm{GPa}$, whereas the median PR value in such measurement conditions amounts to 0.18 . The best geomechanical conditions were identified in the highest part of PZ1, often contaminated by carbonates from younger strata, where the $\mathrm{YM}$ is higher than in the middle part of the formation.

\section{CHARACTERISTICS OF PZ2}

\section{STRATIGRAPHY, LITHOLOGY AND LITHOFACIES}

The stratigraphic range of $\mathrm{PZ2}$ corresponds to the range of the Sasino Formation, but its lateral distribution is much smaller because the prospective criteria were not fulfilled (thickness $>10 \mathrm{~m}$ and TOC $>1.5 \mathrm{wt}$.\%). In the western part of the Baltic Depression the strata represent the entire Llanvirn and Caradoc (Darriwilian, Sandbian and Lower Katian), from the Hustedograptus teretiusculus to the Climacograptus styloideus biozones. The range of $\mathrm{PZ} 2$ is modified compared to the range established earlier (Podhalańska et al., 2016a, b) to access to data from newly drilled boreholes and change of criteria.

PZ2 occurs only in the western, marginal part of the EEC in two areas, i.e. the Łeba Elevation with the adjacent offshore area, where it partly corresponds to PZ1, and in the northern part of Płock-Warszawa Trough (Fig. 13).

PZ2 extends onto a large inland part of the Łeba Elevation with the boreholes Żarnowiec IG 1 (34.1 m), Łeba 8 (48 m), Białogóra 1, Białogóra 2, Lublewo LEP 1 (35 m), Łebień 1 (25.4 m), Opalino 2 (25.5 m), Opalino 3 (26.0 m), Tępcz 1 (21 m), Borcz 1 (15.3 m), Miłowo $1(16 \mathrm{~m})$ and others. Offshore, PZ2 occurs in boreholes B16-1/85, where it reaches a thickness of $67 \mathrm{~m}, \mathrm{~B} 21-1 / 95(57.5 \mathrm{~m})$, and B21-2/2014 (54 m). Its maximum thickness in the Baltic area is $\sim 70 \mathrm{~m}$ (Fig. 13). The largest thickness of PZ2 corresponds to the maximum thickness recognised of the Sasino Formation.

In the Płock-Warszawa Trough, PZ2 was tentatively distinguished based on the presence of these deposits e.g. in boreholes RYP Lutocin 1 with a thickness of $30 \mathrm{~m}$, and a boundary thickness with regard to the accepted thickness criteria of $9.9 \mathrm{~m}$ in borehole BRO-NM Lubawskie-01. These deposits represent the Sandbian and Lower Katian.

PZ2 comprises black and black-grey claystones and clayey siltstones, occasionally siltstones, representing lithofacies from sets L-1 and L-3 (Feldman-Olszewska and Roszkowska-Remin, 2016). A succession comprising only the prospective lithofacies mentioned above was noted in borehole Tępcz 1 and in the lower and upper part of the succession in boreholes: Niestępowo 1 and Łeba 8. In the central part of PZ2, in boreholes Darżlubie IG 1, Borcz 1, Wysin 1, Białogóra 1, Opalino 2 and Opalino 3, the Sasino Formation is characterized by a tripartite lithofacies distribution. Prospective lithofacies from sets L-1 and L-3 - massive and/or laminated thin claystones and clayey siltstones - often with a large content of pyrite concretions or dispersed pyrite, occur in the basal and top- 


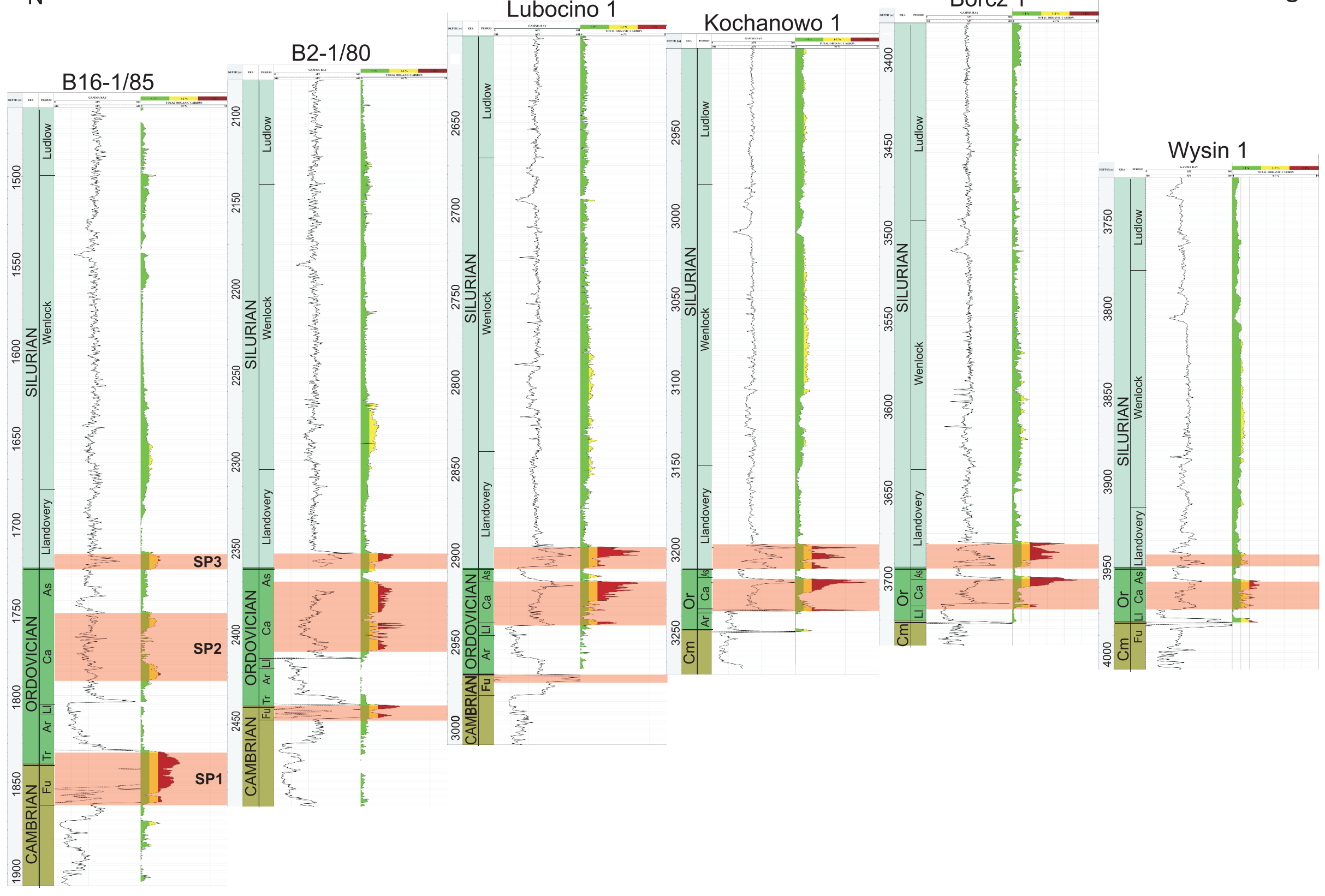

Fig. 9. Correlation of the prospective zones (PZ) along the line B16-1/85 - Wysin 1 (western part of the Baltic Depression; compare Fig. 2); the interpretation for B16-1/85 and B2-1/80 according to the Oil and Gas Institute - NRI; Lubocino 1, Kochanowo 1, Borcz 1, Wysin 1 according to Podhalańska et al. (2016), modified; from left to right: chronostratigraphy, gamma ray and TOC log 


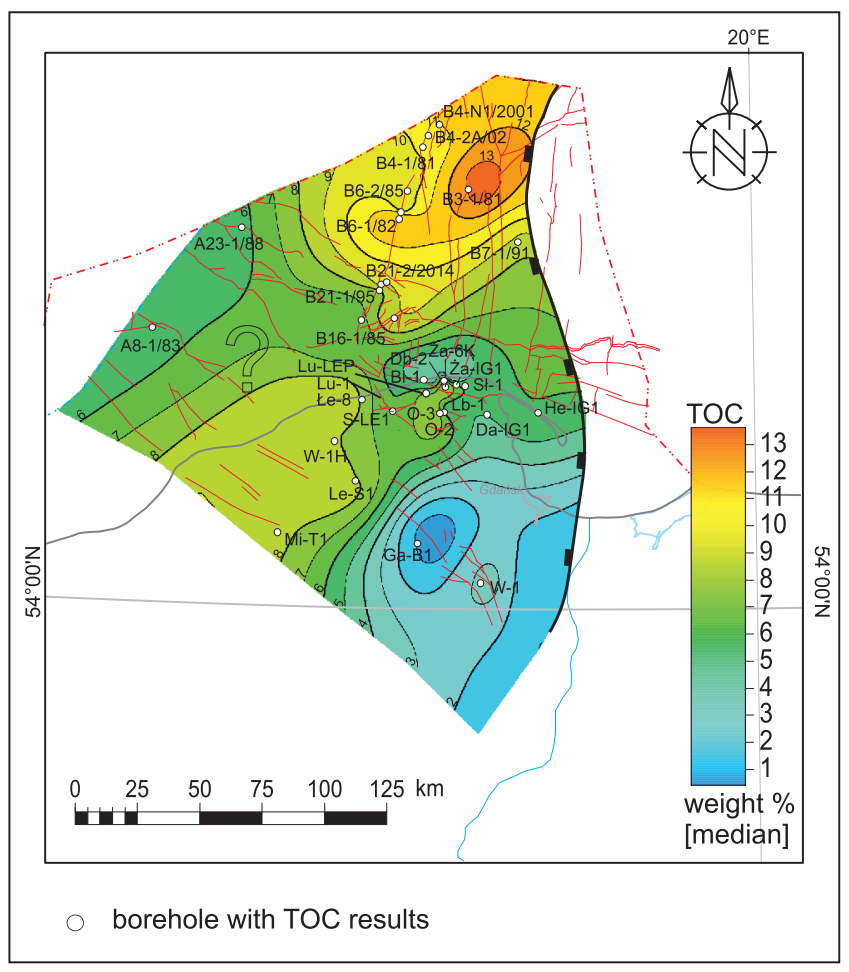

Fig. 10. Total Organic Carbon map for the Piaśnica Formation Explanations on Figures 5 and 6

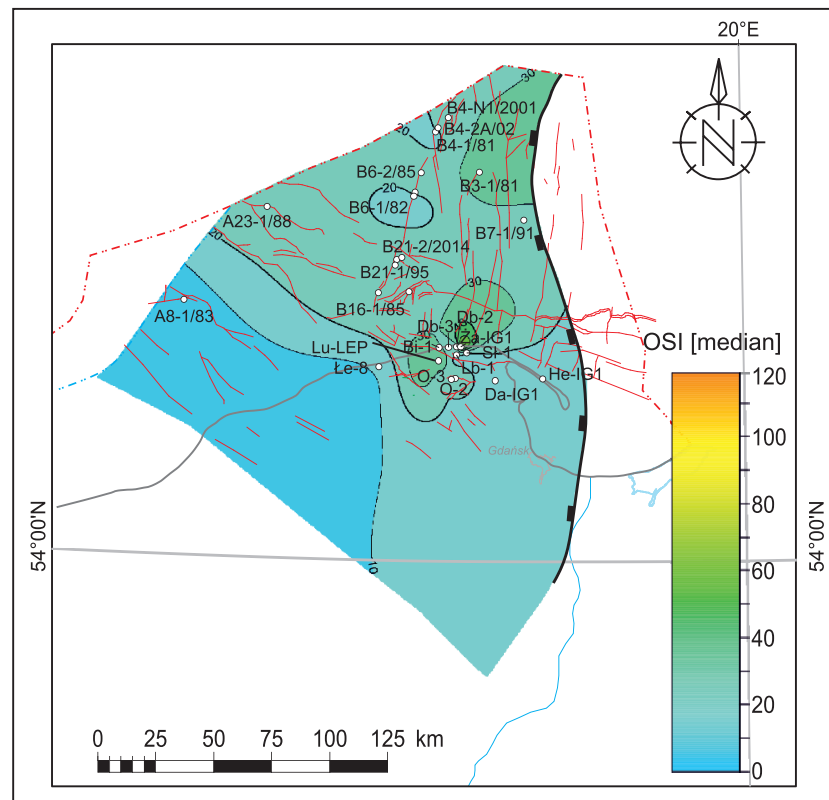

borehole with OSI measurement

Fig. 11. Oil Saturation Index map for the Piaśnica Formation

Other explanations see Figures 5-7

most parts of the succession, where the middle part (Diplograptus multidens Biozone representing the Sandbian) comprises bioturbated or strongly cemented siltstones (silica/dolomite) with numerous interbeds of tuffite and bentonite. This tri-
Table 5

Median values of particular petrophysical properties in the Piaśnica Formation and the number of samples taken for analysis

\begin{tabular}{|l|c|c|}
\hline \multicolumn{1}{|c|}{ Measurement } & $\begin{array}{c}\text { Median } \\
\text { value }\end{array}$ & $\begin{array}{c}\text { Number } \\
\text { of samples }\end{array}$ \\
\hline Total porosity NMR [\%] & 3.17 & 7 \\
\hline Effective porosity NMR [\%] & 0.37 & 1 \\
\hline $\begin{array}{l}\text { Open porosity [\%] } \\
\text { (estimated by the Oil and Gas } \\
\text { Institute-NRI) }\end{array}$ & 3.22 & 44 \\
\hline $\begin{array}{l}\text { Effective porosity [\%] } \\
\text { (estimated by TerraTek) }\end{array}$ & 3.02 & 4 \\
\hline $\begin{array}{l}\text { Porosity filled with gas [\%] } \\
\text { (estimated by TerraTek) }\end{array}$ & 1.73 & 4 \\
\hline
\end{tabular}

\section{NMR - Nuclear Magnetic Resonance}

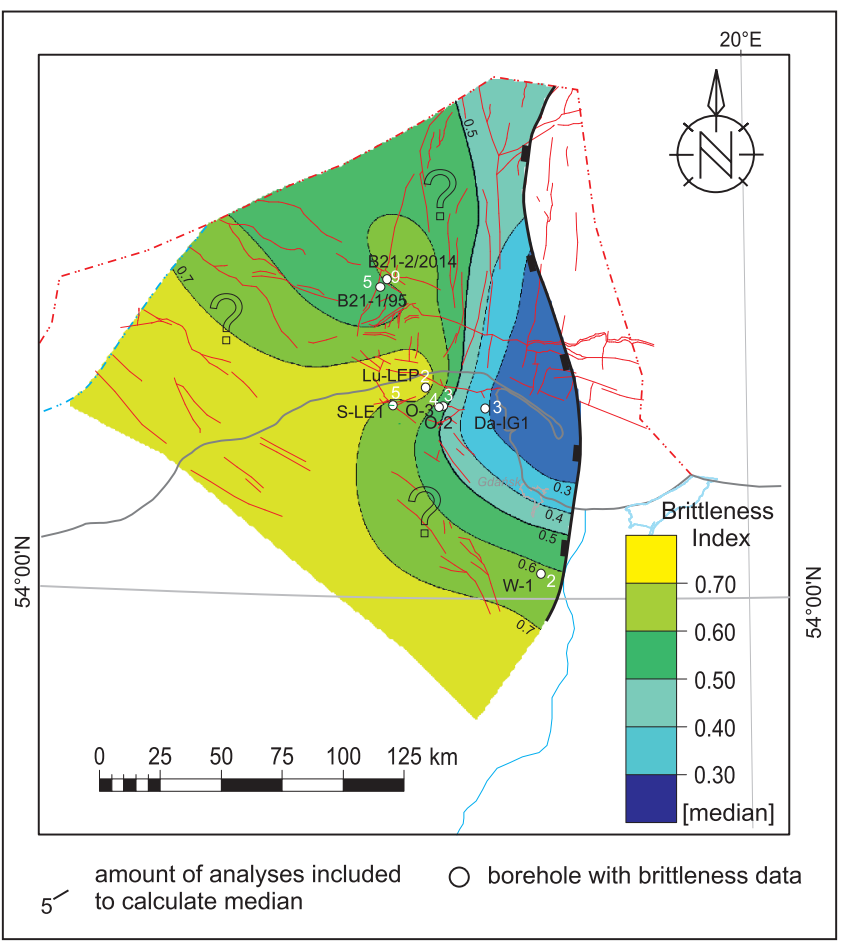

Fig. 12. Brittleness index map for the Piaśnica Formation

Other explanations on Figures 5 and 6

partite composition is observed mainly in the borehole logs of e.g. Wysin 1, Borcz 1 (Fig. 9) as well as Gapowo 1, Białogóra 1 and Białogóra 2.

\section{PETROGRAPHY AND MINERALOGY}

Rocks belonging to PZ2 were characterized in light microscopy as dark brown and brown claystones with an admixture of silt and occasionally bioclasts. The rocks display a directional texture (laminated or flaser-bedded), and muddy or muddy-silty composition. The detrital material includes grains of quartz or potassium feldspar, indicating cathodoluminescence $(\mathrm{CL})$ colours of light blue, plagioclases with greenish or blue luminescence, 


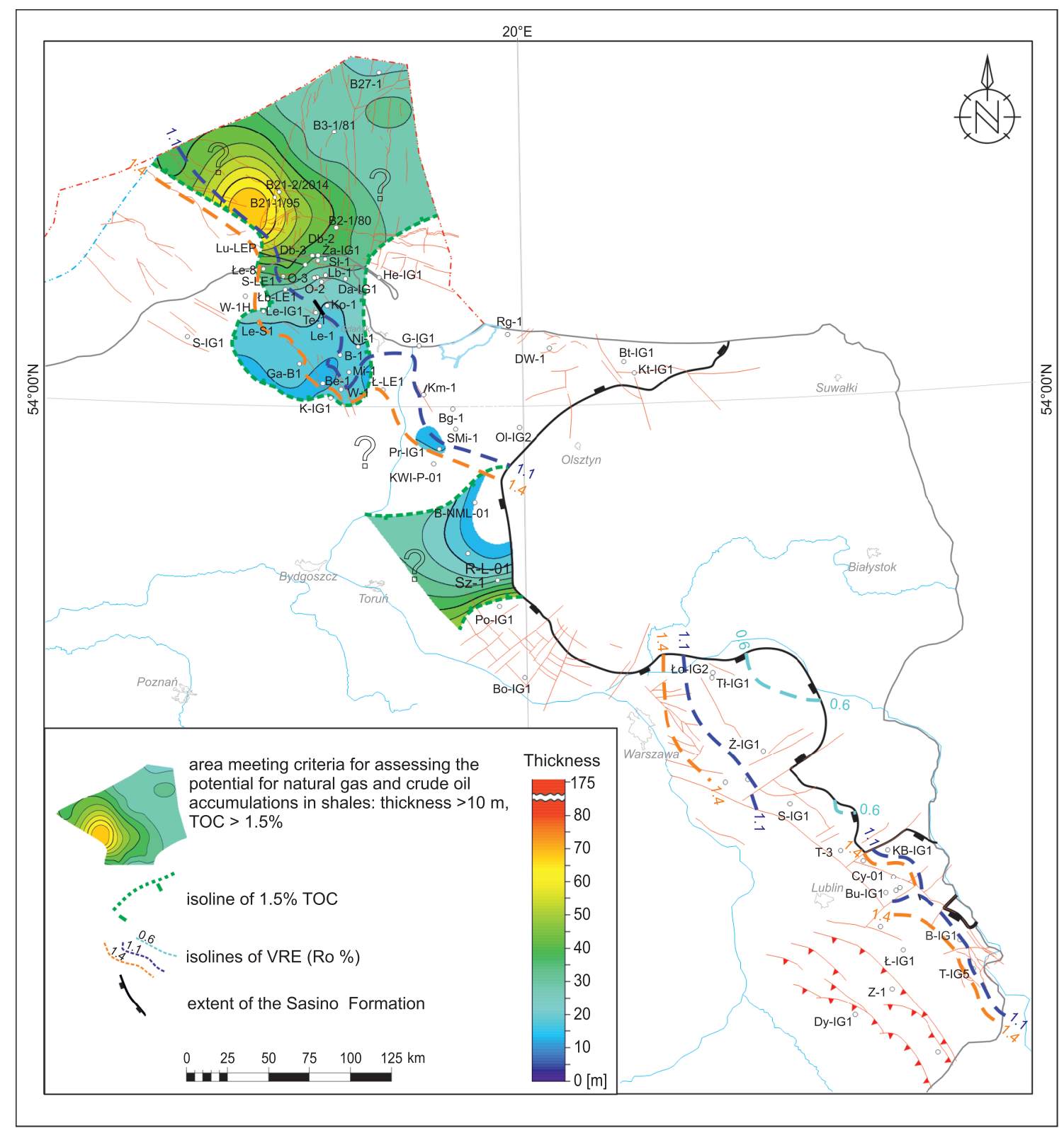

Fig. 13. PZ2 map

apatite and pyrite grains. The pelitic fraction comprises clay minerals, occasionally with carbonate micrite. XRD analysis indicates that rocks of the prospective zone are characterized by a high clay content (up to a boundary value of $60 \%$ ). The clay minerals include micas, illite, mixed-packet illite/smectite minerals, and chlorite. SEM analysis has shown the presence of ankerite, dolomite, calcite, anhydrite and celestine. Laminae of organic matter and calcite veins have also been noted (SikorskaJaworowska et al., 2016; Kuberska, 2018).

\section{GEOCHEMISTRY AND THERMAL MATURITY} OF THE ORGANIC MATTER

In the northern part of PZ2 in the Łeba Elevation, the Sasino Formation is usually trimodal, with the basal and topmost part strongly enriched in organic carbon and therefore representing good to very good source rocks. The middle part, impoverished in organic carbon, represents fine clastic rocks with a significant admixture of pyroclastic minerals. The southern part of PZ2 in the Płock-Warszawa Trough displays a different lithology, because only one unit of siltstone-claystone source rocks has been distinguished there within the formation. For the characteristics of PZ2, the Sasino Formation was treated as a whole, and the median values of geochemical parameters characterize the entire formation not distinguishing the basal, middle and topmost parts. The TOC content is from 1.5 to $>3.5 \mathrm{wt} \%$ which indicates good and very good quality source rocks (Table 2). The highest TOC values (>3 wt.\%) were noted along the Darżlubie-Lubocino-Opalino-Tępcz-Lewino-Borcz-Miłowo area in the inland part of PZ2 (Fig. 14). Lower values (>2-3 wt.\%) occur along the Lebork-Gapowo-Będomin-Wysin and Nowe Miasto LubawskieSzymkowo-Lutocin areas in the inland part of PZ2 and in the northern, offshore part of the Łeba Elevation. OSI ranges from 


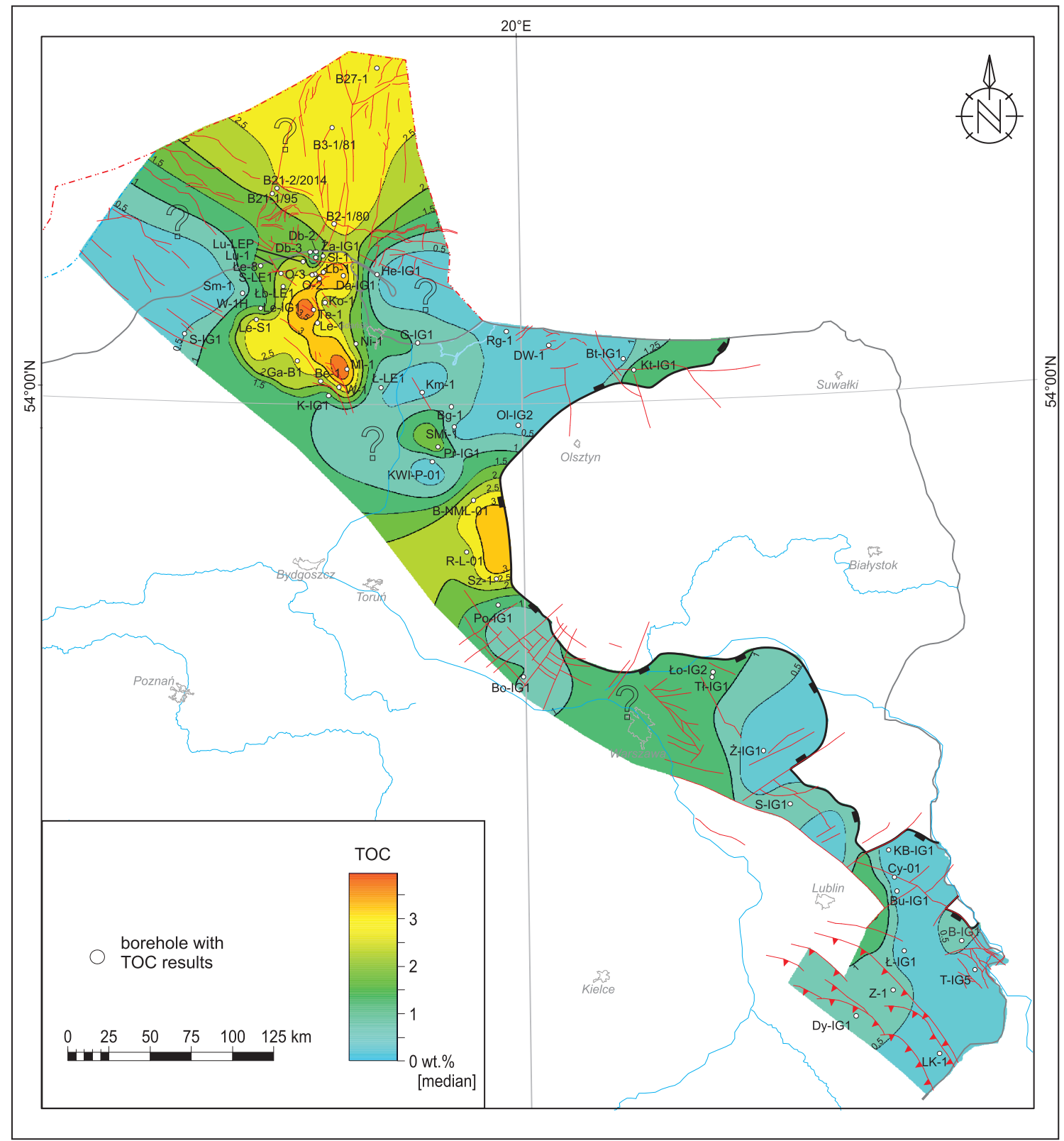

Fig. 14. Total Organic Carbon map for the Sasino Formation

Abbreviation of borehole not cited on Figures 5-7: Szymkowo 1 - Szy-1; other explanations on Figures 5 and 6

$<10$ to $>100 \mathrm{mg} \mathrm{HC} / \mathrm{g}$ TOC which indicates a broad range of thermal maturity from low to high (Table 4). The highest OSI values (>100 mg HC/g TOC), pointing most probably also to high oil saturations, were noted near the Lublewo, Białogóra, Dębki, Żarnowiec areas and in the offshore borehole B2-1/80 (Fig. 15).

$T_{\text {max }}$ values range from $>430$ to $>570^{\circ} \mathrm{C}$, which point to thermal maturity from the beginning of the oil window to the dry gas/?overmature windows within SP2. The Łeba Elevation is located in the oil window $\left(435-445^{\circ} \mathrm{C}\right)$, and to the west and south-west the thermal maturity increases, which is reflected in a $T_{\max }$ of $>460^{\circ} \mathrm{C}$ (wet gas window) near Łeba, Łebień, Kochanowo, Tępcz and Lewino areas. Further increases of $T_{\max }$ values are observed near the Warblino, Lębork, Wysin and
Nowe Miasto Lubawskie areas in the southern part of SP2 $\left(>500^{\circ} \mathrm{C}\right.$; dry gas/overmature windows) and in the deeper part of the basin near the Wysin $\left(>480^{\circ} \mathrm{C}\right.$; dry gas window), Będomin and Kościerzyna areas $\left(>560^{\circ} \mathrm{C}\right.$; dry gas/?overmature window).

Reflectivity values of vitrinite-like macerals (e.g., graptolites, chitinozoans and stable bitumen) recalculated into the vitrinite reflectivity scale (\% VRE; Jacob, 1989; Makos et al., 2016) point to the oil window $(0.6-1.1 \%$ VRE) over a large part of the Łeba Elevation with a significant increase near the Żarnowiec area. To the south-west of the Łeba Elevation and to the south-east of the Prabuty area occurs a wet gas window $(1.1-1.4 \%$ VRE). A dry gas window is postulated near the Gapowo, Będomin and Kościerzyna areas, and to the south and south-west of BRO-NM Lubawskie-01 borehole location 


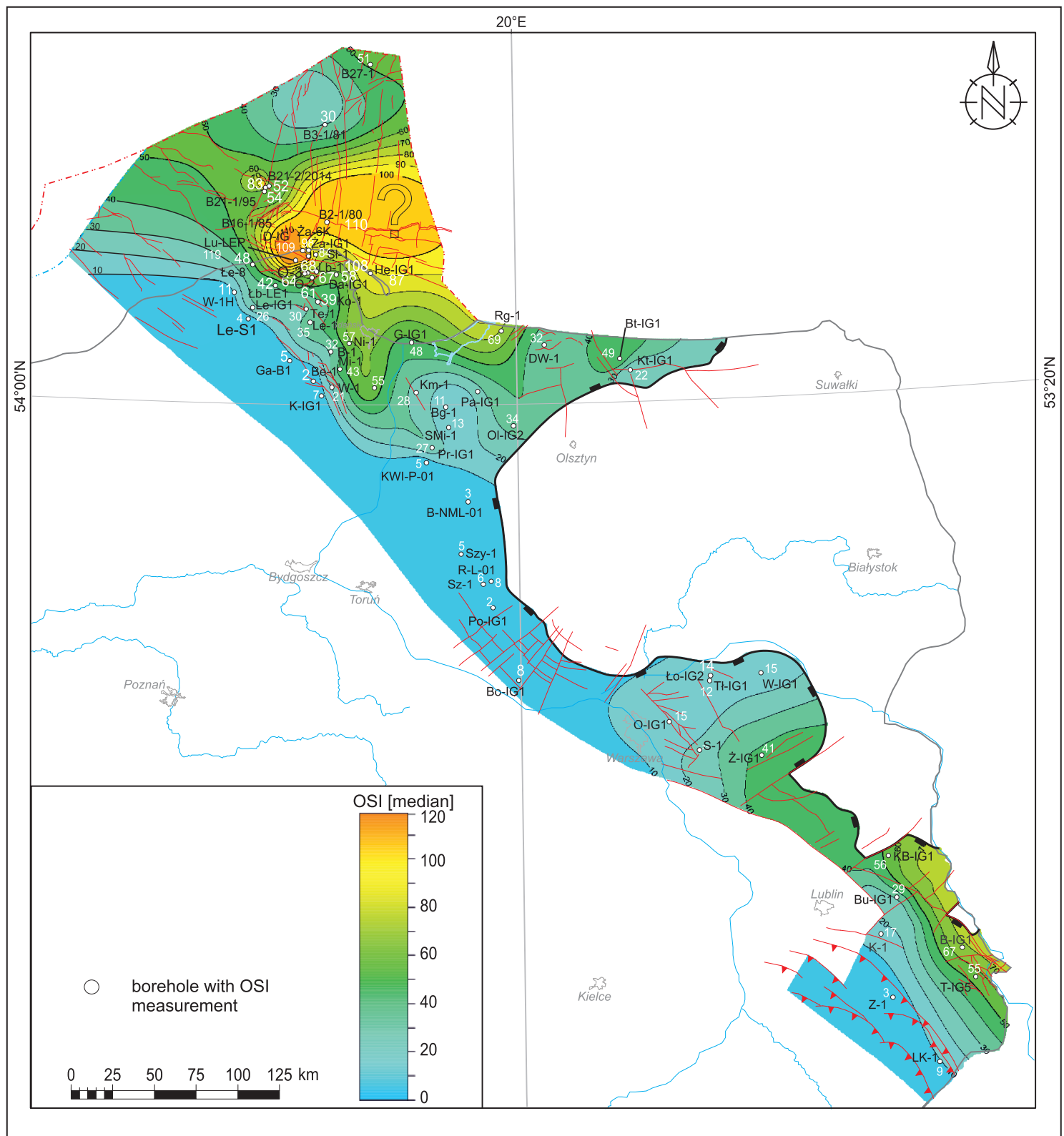

Fig. 15. Oil Saturation Index map for the Sasino Formation

Abbreviation of borehole not cited on Figures 5-7: Wrotnów IG 1 - W-IG1; other explanations on Figures 5 and 6

$(>1.4 \%$ VRE), which indicates the correctness of the interpretation of thermal maturity based on $T_{\max }$.

Kerogen in the Sasino Formation is the oil-prone type II, which comprises vitrinite-like macerals mixed with clay, forming an organic-mineral association, of which the main components include solid bitumen and organic clasts degraded by bacteria (Grotek, 2016).

\section{AVERAGE TOTAL GAS CONTENT}

Median values of the total gas content exceed $1.5 \mathrm{~m}^{3} / \mathrm{t}$ near the Opalino, Borcz, Lewino, Tępcz and Będomin areas, and near Nowe Miasto Lubawskie in the southern part of SP2. Higher median values $>2 \mathrm{~m}^{3} / \mathrm{t}$ were noted in one borehole near Opalino, and near the Gapowo and Łebien areas, whereas the highest median value of total gas was measured near Lębork at $>6 \mathrm{~m}^{3} / \mathrm{t}$.

\section{PETROPHYSICAL PARAMETERS}

Petrophysical data available for the Sasino Formation are summarized in Table 6. Porosity filled with gas data are available only for 21 boreholes, for which the median value fulfils optimal prospective values. The median value of this parameter is similar in both parts of the basin. Borehole Terebin IG 5 is characterized by anomalously high porosity filled with gas, reaching $14.21 \%$. An area with 3 boreholes with increased gas saturation can be seen on the map to the west of the Mazury-Belarus High. 


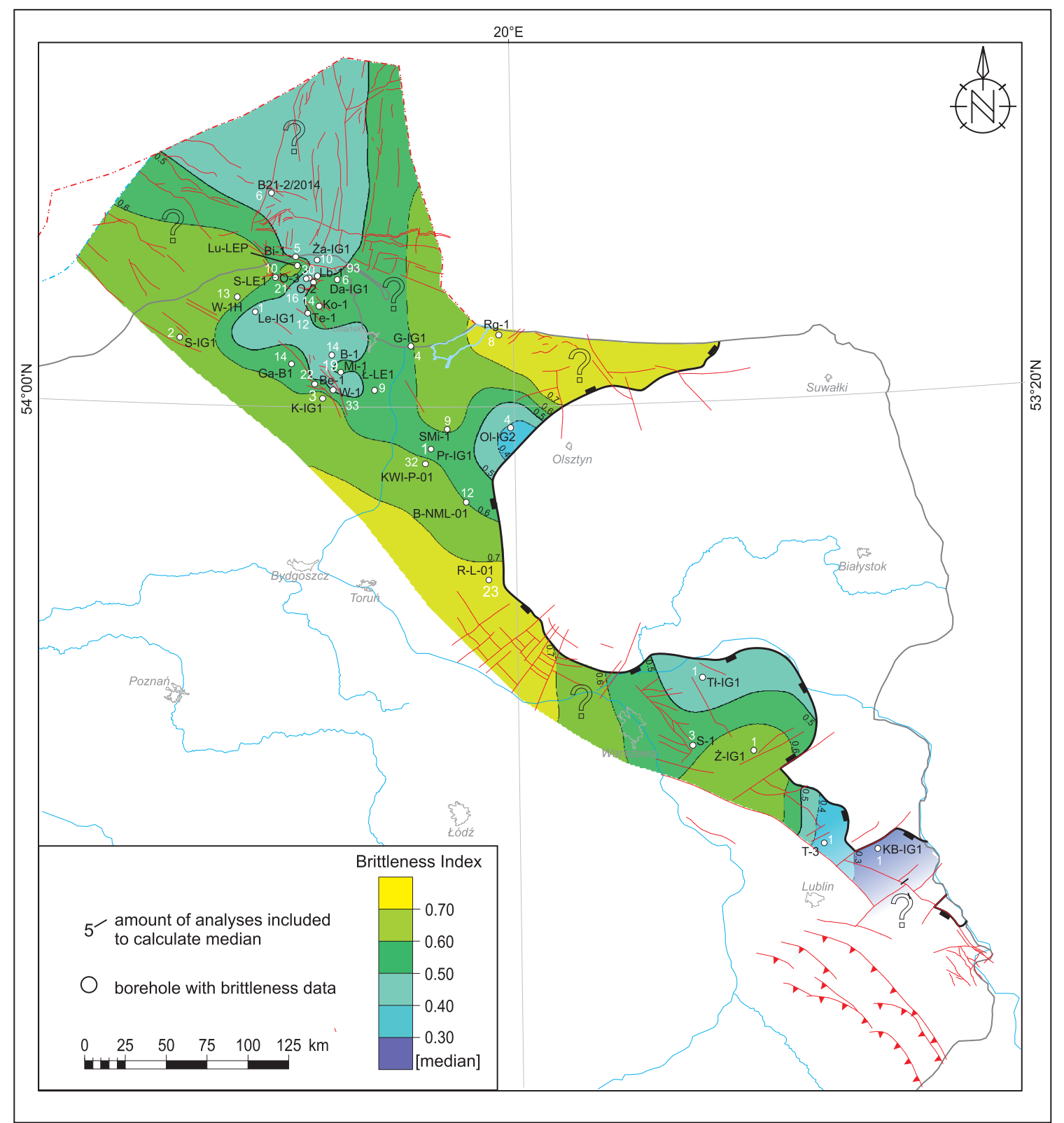

Fig. 16. Brittleness index map for the Sasino Formation

Other explanations on Figures 5 and 6

\section{GEOMECHANICS}

PZ2 is characterized by high internal diversity and variability of geomechanical parameters. It contains carbonate intercalations that cause a significant increase in the $\mathrm{BI}$ and $\mathrm{YM}$, as well as tuffite material that unequivocally decrease the $\mathrm{BI}$ and $\mathrm{YM}$. Treating PZ2 as a geomechanically homogenous unit may result in interpretational errors. Nevertheless, we try to point out herein the median values of the entire prospective zone, being aware that in the case of future exploration, a more detailed approach should be applied.

A zone with an elevated clay mineral content and significant organic matter content, hence a reduced brittleness $(\mathrm{BI}=$ $0.4-0.5)$, extends from borehole Lębork S-1 in the west to borehole Starogard S-1 in the east (Fig. 16). Near the TTZ in the Baltic region, the $\mathrm{BI}$ averages $0.6-0.7$. Most fracture-prone zones occur at the bottom of PZ2, where deposits contami- nated by the carbonate Kopalino Formation show higher YM and $\mathrm{BI}$ values. The median values of the dynamic YM measured parallel to bedding within PZ2 oscillate $\sim 55-60 \mathrm{GPa}$, whereas the PR was estimated at 0.24 . The measurements of these parameters in directions perpendicular to bedding were $\sim 30 \mathrm{GPa}$ and 0.215 , respectively. The tensile strength measured perpendicular to bedding averages $6.1 \mathrm{MPa}$, whereas parallel to bedding it is at $4.6 \mathrm{MPa}$. The unit has a set of orthogonal joints with $0-40^{\circ}$ and $90-130^{\circ}$ strikes. Natural veins are mostly filled with carbonate material. The differential stress is very low, therefore despite the predominance of the strike-slip fault regime, the occurrence of both normal fault and thrust fault regimes was seen within the formation. The direction of $S_{H \max }$ was defined as a NNW-SSE azimuth $150^{\circ} \mathrm{N}$. Comparing geomechanical data with the TOC content, the weakening of the mechanical parameters in zones of increased TOC content (and the content of clay minerals) can be seen. This results in a 


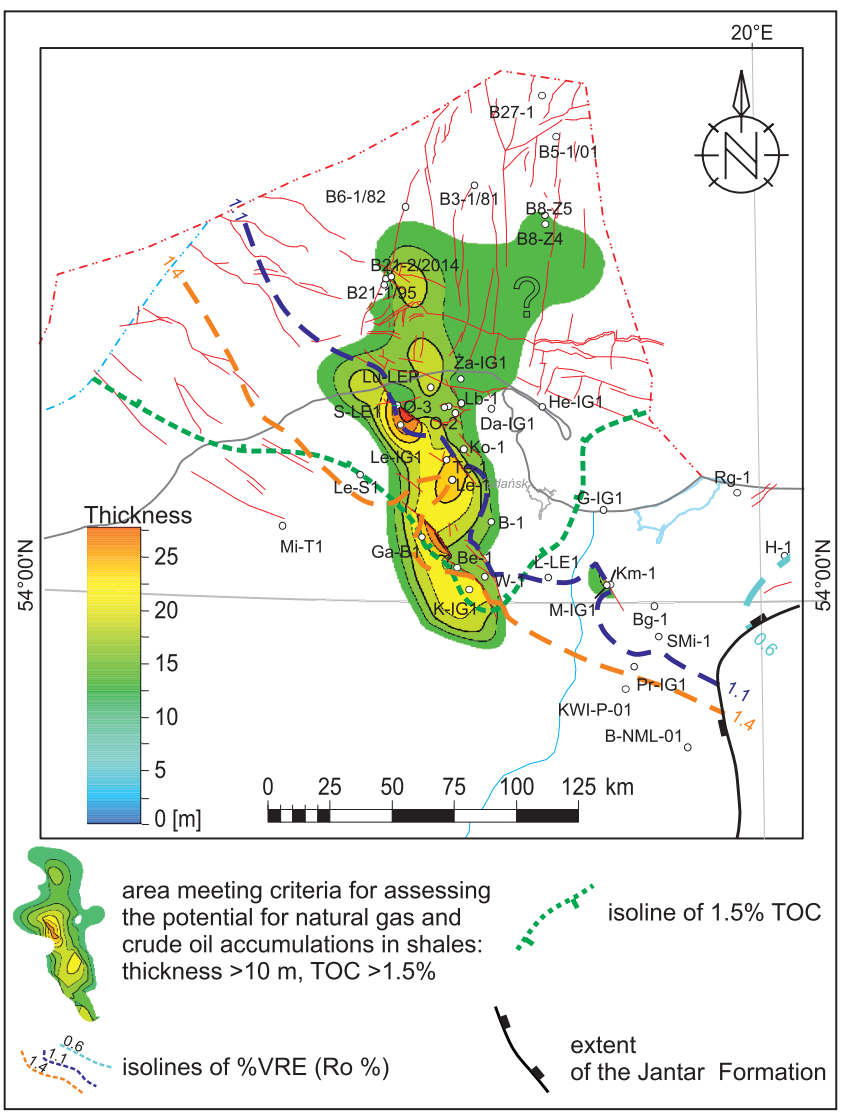

Fig. 17. PZ3 map

Other explanations on Figures 5 and 6

situation where deposits with the best generation parameters along the Baltic Basin have the weakest conditions for conducting intensification treatments.

\section{CHARACTERISTICS OF Z3}

\section{STRATIGRAPHY, LITHOLOGY AND LITHOFACIES}

The range of $P Z 3$ is restricted to the central part of the Łeba Elevation, continuing offshore into the Polish Economic Zone of the Baltic Sea (Fig. 17). The zone only partly overlaps the range of the Jantar Formation (Fig. 7). It extends from boreholes B8-Z4 and B8-Z5 in the north-east, and boreholes B21-1/95 m (10 $\mathrm{m}$ thick), B21-2/2014 (15 $\mathrm{m}$ thick) to the north in the offshore area, through such boreholes as Żarnowiec IG 1, Łeba 8, Łebien LE1 $(20 \mathrm{~m})$ and Lewino 1G 2 in the central part. In the south, PZ3 was noted in boreholes Wysin 1 (13 m), Borcz 1 (13.7 m), Kościerzyna IG 1 (18 m) and Tępcz 1 (20 m).

PZ3 comprises dark mudstones, bituminous, mostly massive, non-bioturbated, rarely poorly bioturbated, with numerous graptolites and many fine pyrite concretions. The dominant lithofacies assemblage is prospective set L-1 (Feldman-Olszewska and Roszkowska-Remin, 2016). The succession of the Jantar Formation, to which PZ3 is restricted, is characterized by very low variability.

The lower boundary of PZ3 corresponds to the lower boundary of the Jantar Formation. In some cases there are lighter-coloured mudstones in the boreholes with a continuous Ordovician/Silurian boundary, e.g. Łeba 8 and Białogóra 1. In these boreholes, sedimentation of claystones with individual graptolites took place, reflecting the beginning of the transgression in the Late Hirnantian. Usually, however, the beginning of sedimentation of the Jantar Formation is linked with a small stratigraphic gap at the Ordovician/Silurian boundary and with an erosive surface emphasized by the presence of pyrite. In the westernmost part of the Baltic Depression the beginning of the sedimentation of the Jantar Formation and thus deposits of PZ3 correspond to the lowermost Rhuddanian (Akidograptus ascensus or Parakidograptus acuminatus biozones). The stratigraphic range of $\mathrm{PZ3}$ in this area corresponds to the Rhuddanian (in places Upper Hirnantian) and Aeronian up to the Coronograptus gregarius Biozone (Demirastrites triangulatus Subzone). The largest thicknesses of zone PZ3 were noted in boreholes Tępcz 1 (20 m) and Łebień LE-1 (20 m).

\section{PETROGRAPHY AND MINERALOGY}

Rocks of PZ3 in optical microscopy are characterized by black-brown claystones, locally dark brown calcareous siltstones or dark brown micritic limestones (Sikorska-Jaworowska et al., 2016; Kuberska, 2018). The claystones display a directional structure - flaser-bedding or lamination - and a muddy or muddy/silty composition. The laminae are composed of organic matter with iron compounds. Carbonate laminae also occur. The admixture of detrital material is represented by quartz and potassium feldspar grains (light blue lu-

Median values of particular petrophysical parameters in the Sasino Formation and the number of samples used for the analysis

\begin{tabular}{|c|c|c|c|c|}
\hline \multirow{3}{*}{ Measurement } & \multicolumn{4}{|c|}{ Region } \\
\hline & \multicolumn{2}{|c|}{ Pomerania (Baltic area) } & \multicolumn{2}{|c|}{ Lublin and Podlasie } \\
\hline & Median & $\begin{array}{c}\text { Number } \\
\text { of samples }\end{array}$ & Median & $\begin{array}{c}\text { Number } \\
\text { of samples }\end{array}$ \\
\hline Total porosity NMR [\%] & 6.92 & 136 & 2.69 & 14 \\
\hline Total porosity [\%] (estimated by the Oil and Gas Institute-NRI) & 6.05 & 281 & 8.65 & 14 \\
\hline Total porosity [\%] (estimated by TerraTek) & 4.13 & 48 & 5.82 & 9 \\
\hline Effective porosity NMR [\%] & 2.50 & 31 & & \\
\hline Open porosity [\%] (estimated by the Oil and Gas Institute-NRI) & 5.50 & 242 & & \\
\hline Effective porosity [\%] (estimated by TerraTek) & 2.74 & 44 & & \\
\hline Porosity filled with gas [\%] (estimated by TerraTek) & 1.11 & 48 & & \\
\hline Porosity filled with gas [\%] (estimated by CoreLab) & 2.71 & 67 & 2.62 & 15 \\
\hline
\end{tabular}




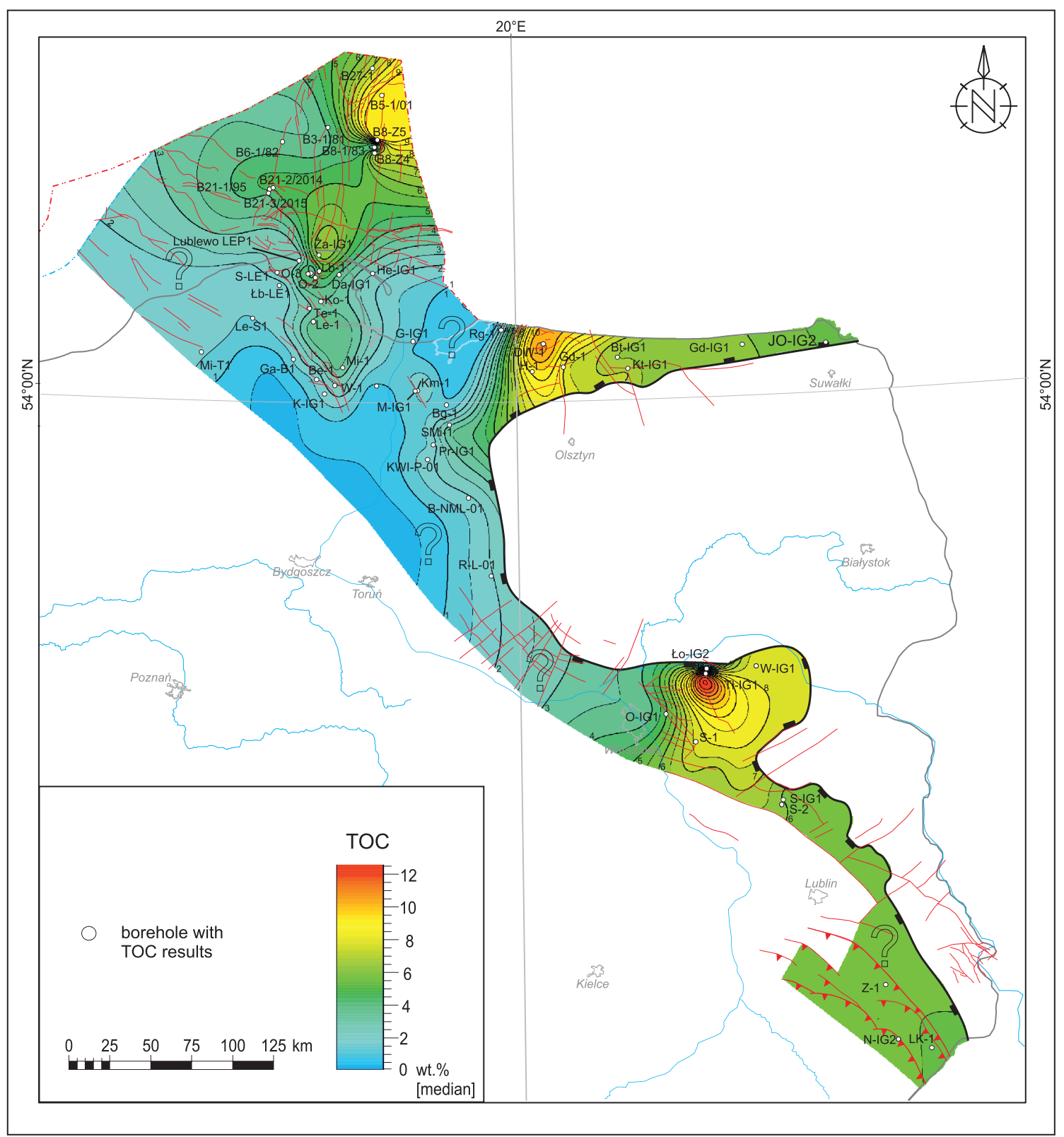

Fig. 18. Total Organic Carbon map for the Jantar Formation

Other explanations on Figures 5-7

minescence in $\mathrm{CL}$ ). Carbonate grains, mainly calcite, fine concentrations of pyrite, and fine anhydrite crystals have also been noted.

The calcareous siltstone is composed of carbonate micrite with an admixture of clay minerals. Fine concentrations of pyrite and admixtures of potassium feldspars and quartz occur there.

$\mathrm{XRD}$ analysis indicated a variable content of clay minerals (35 to $60 \%$ ). These include micas, illite, mixed-layered illitesmectite minerals and chlorite.

\section{GEOCHEMISTRY AND THERMAL MATURITY OF THE ORGANIC MATTER}

The TOC content in PZ3 is from 1.5 to 6 wt. \% which shows that the Jantar Formation is a very good quality source rock (Table 2). The highest TOC values (>3 wt.\%) were noted along the line designated by the following locations: Debki-Opalino-Lubocino-Darżlubie-Kochanowo-Tępcz-Lewino-Bocz-Miłowo-Wysin in the onshore part of PZ3 and in the offshore part of PZ3 on the Łeba Elevation, particularly near the B21 and B8 oil and gas offshore fields (Fig. 18). The OSI is from 30 to 80 $\mathrm{mg} \mathrm{HC} / \mathrm{g}$ TOC showing early to mature, stained source rock (Table 4). The highest OSI values (>100 mg HC/g TOC), indicating high saturation of the formation with hydrocarbons, were noted near the Lublewo area, which might be due to oil-based mud core contamination (Fig. 19). Values of $T_{\max }$ are from $>440$ to $>580^{\circ} \mathrm{C}$, which corresponds to thermal maturity from the beginning of the oil window to the dry gas/?overmature windows (Table 3) within PZ3 (Fig. 20). The Łeba Elevation is located within the oil-generation window $\left(440-450^{\circ} \mathrm{C}\right)$, increasing to the west and south-west as reflected in $T_{\max }$ values $>460^{\circ} \mathrm{C}$ (wet gas window) near the Łeba, 


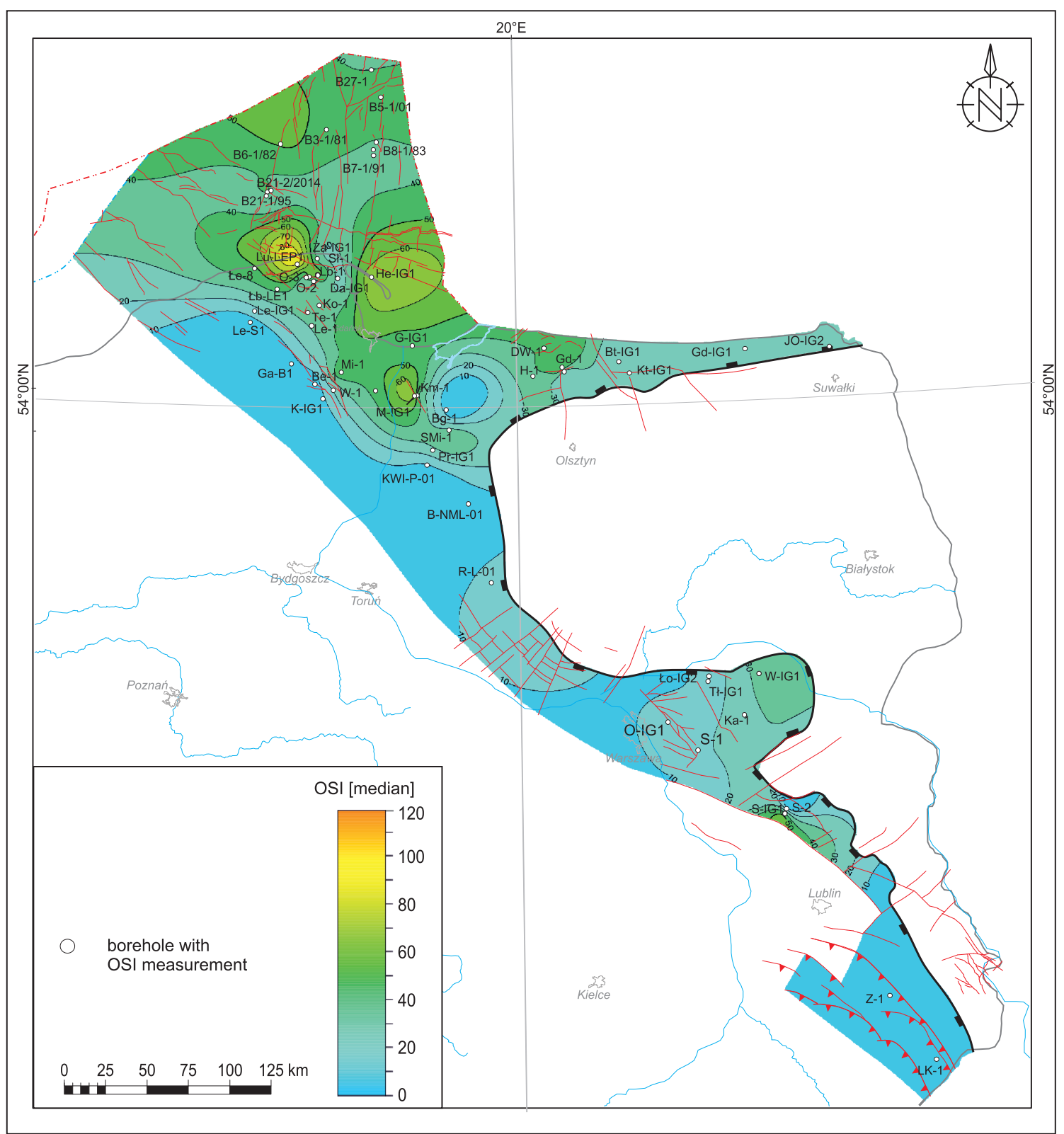

Fig. 19. Oil Saturation Index map for the Jantar Formation

Other explanations on Figures 5-7

Łebień, Kochanowo, Tępcz and Lewino areas. Further increase of $T_{\max }$ values may be observed near the Wysin $\left(>480^{\circ} \mathrm{C}\right.$; dry gas window) and Kościerzyna areas (dry gas/?overmature window) in the southern part of PZ3, likely as a result of deeper tectonic burial.

The interpretation of thermal maturity of the organic matter based on $T_{\max }$ values in the PZ3 area is in accordance with the results of reflectivity of vitrine-like macerals, recalculated to the vitrinite reflectivity scale (\%VRE; Jacob, 1989; Makos et al., 2016; Fig. 21).

Organic matter dispersed in the rocks of the Jantar Formation is the oil-prone type II kerogen, composed of solid bitumen, phytoclasts, as well as vitrinitized or fusinitized trilobite remains (Grotek, 2016).

\section{AVERAGE TOTAL GAS CONTENT}

The median values of total gas content are equal to or exceed $1.5 \mathrm{~m}^{3} / \mathrm{t}$ near the Opalino, Lewino and Łebień areas. Higher values of desorbed and total gas content were obtained from the Jantar Formation also in the Podlasie-Lublin Basin, where other prospective criteria have not been fulfilled.

\section{PETROPHYSICAL PARAMETERS}

Petrophysical data for the formation are summed up in Table 7. Data for porosity filled with gas are available only for 18 boreholes, in 9 of which the median value fulfils the optimal pro- 


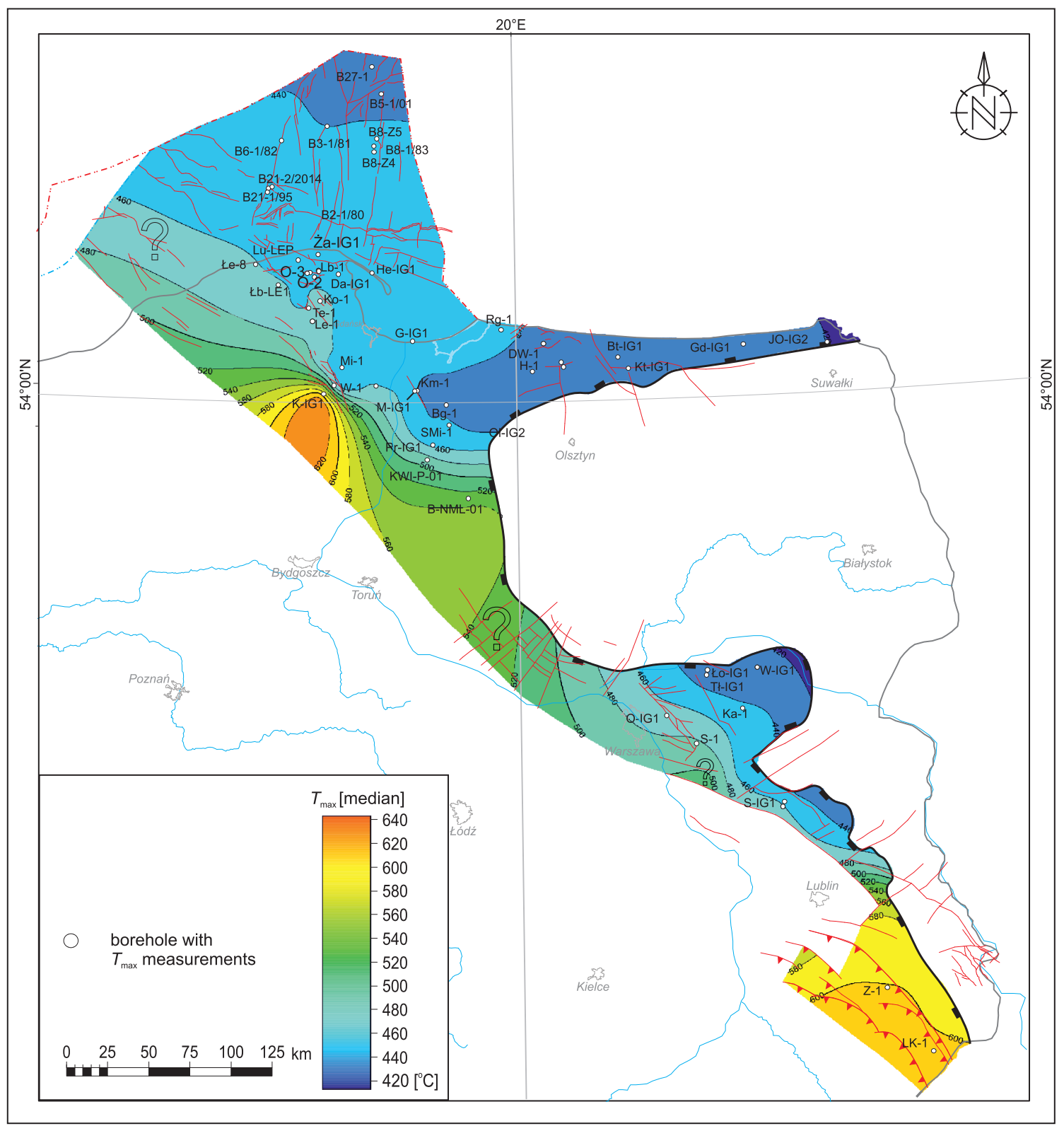

Fig. 20. Thermal maturity map based on $T_{\max }$ measurements for the Jantar Formation

Other explanations on Figures 5-7

spective conditions. The median values of this parameter in the Lublin and Podlasie areas are much lower than the median value for Pomerania. The distribution map shows a distinct concentration of 4 boreholes located to the south of Gdańsk that are characterized by increased saturation in gas.

\section{GEOMECHANICS}

The highest values of prospective properties of $\mathrm{PZ}$, taking into account the geomechanical features, are present in the northern inland area of the Baltic Basin. The best parameters were achieved in the boreholes Łebien LE-1 and Strzeszewo $\mathrm{LE}-1$. This area is characterized by a relatively high thickness of SP3 (>15-20 m), high organic matter content and mechanical parameters allowing for the effective implementation of hydraulic fracturing treatments (high $\mathrm{YM}$ and $\mathrm{BI}$ ).
The median value of $\mathrm{BI}$ in $\mathrm{PZ3}$ is 0.45 . The unit is heterogeneous, therefore zones with higher/lower brittleness can be distinguished. The low amount of carbonates causes that $\mathrm{BI}$ depends mainly on the ratio of clay minerals to quartz and feldspar. In the low-thickness zones, PZ3 deposits have higher brittleness, with the exception of the Łebień LE-1 and Strzeszewo LE-1 boreholes, where both high $\mathrm{BI}$ and thicknesses were present (Fig. 22). The median values of YM measured parallel to bedding oscillated $\sim 55-60$ GPa whereas PR was estimated at 0.25 . The measurements of these parameters in the direction perpendicular to bedding were $\sim 28 \mathrm{GPa}$ and 0.21 , respectively. The tensile strength measured perpendicular to bedding was very low, averaging at $4.2 \mathrm{MPa}$, and parallel to bedding was at 3.4 MPa. The UCS strength analysed during the scratch test varied between 60-90 MPa. The density of natural fractures visible in the XRMI and during core analysis is higher than in unit SP2, whereas the bedding is more homogeneous over the entire formation. 


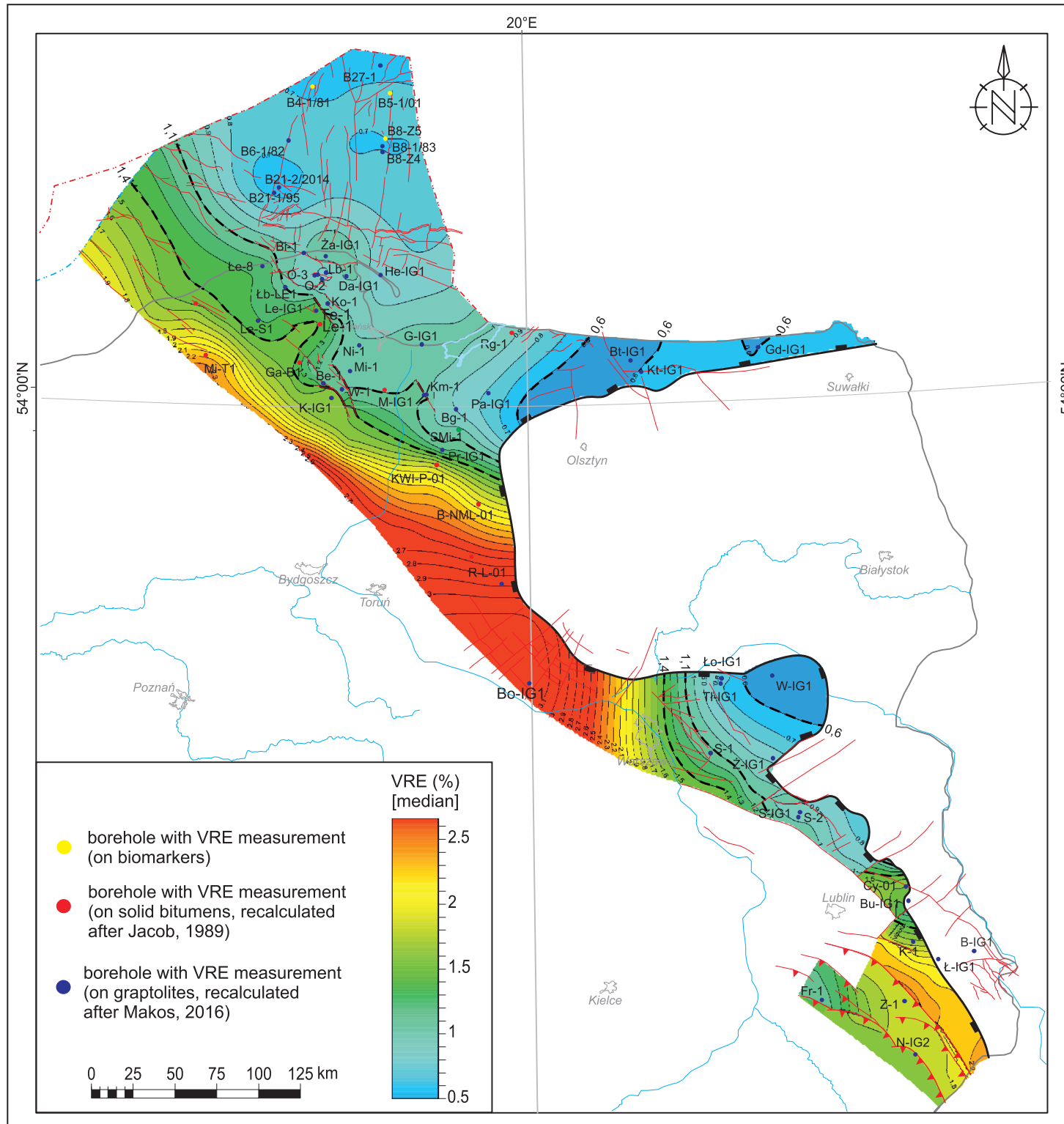

Fig. 21. Thermal maturity map based on Vitrinite Reflectance Equivalent for the Jantar Formation

Abbreviation of borehole not cited on Figures 5-7 and 14: Frampol 1 - Fr-1; other explanations on Figures 5, 6 and 8

Porosity parameters of the Jantar Formation

\begin{tabular}{|l|c|c|c|c|}
\hline \multirow{2}{*}{\multicolumn{1}{|c|}{ Measurement }} & \multicolumn{4}{c|}{ Region } \\
\cline { 2 - 5 } & Pomerania (Baltic area) & \multicolumn{2}{c|}{ Lublin and Podlasie } \\
\cline { 2 - 5 } & Median & $\begin{array}{c}\text { Number } \\
\text { of samples }\end{array}$ & Median & $\begin{array}{c}\text { Number } \\
\text { of samples }\end{array}$ \\
\hline Total porosity NMR [\%] & 6.83 & 109 & 6.69 & 2 \\
\hline Total porosity [\%] (estimated by the Oil and Gas Institute-NRI) & 5.62 & 208 & 1.82 & 2 \\
\hline Total porosity [\%] (estimated by TerraTek) & 4.49 & 41 & 6.50 & 2 \\
\hline Effective porosity [\%] & 2.05 & 19 & 1.95 & 1 \\
\hline Open porosity [\%] (estimated by the Oil and Gas Institute-NRI) & 4.94 & 188 & & \\
\hline Effective porosity [\%] (estimated by TerraTek) & 2.78 & 20 & & \\
\hline Porosity filled with gas [\%] (estimated by TerraTek) & 1.67 & 27 & & 4 \\
\hline Porosity filled with gas [\%] (estimated by CoreLab) & 2.58 & 31 & 1.60 & \\
\hline
\end{tabular}




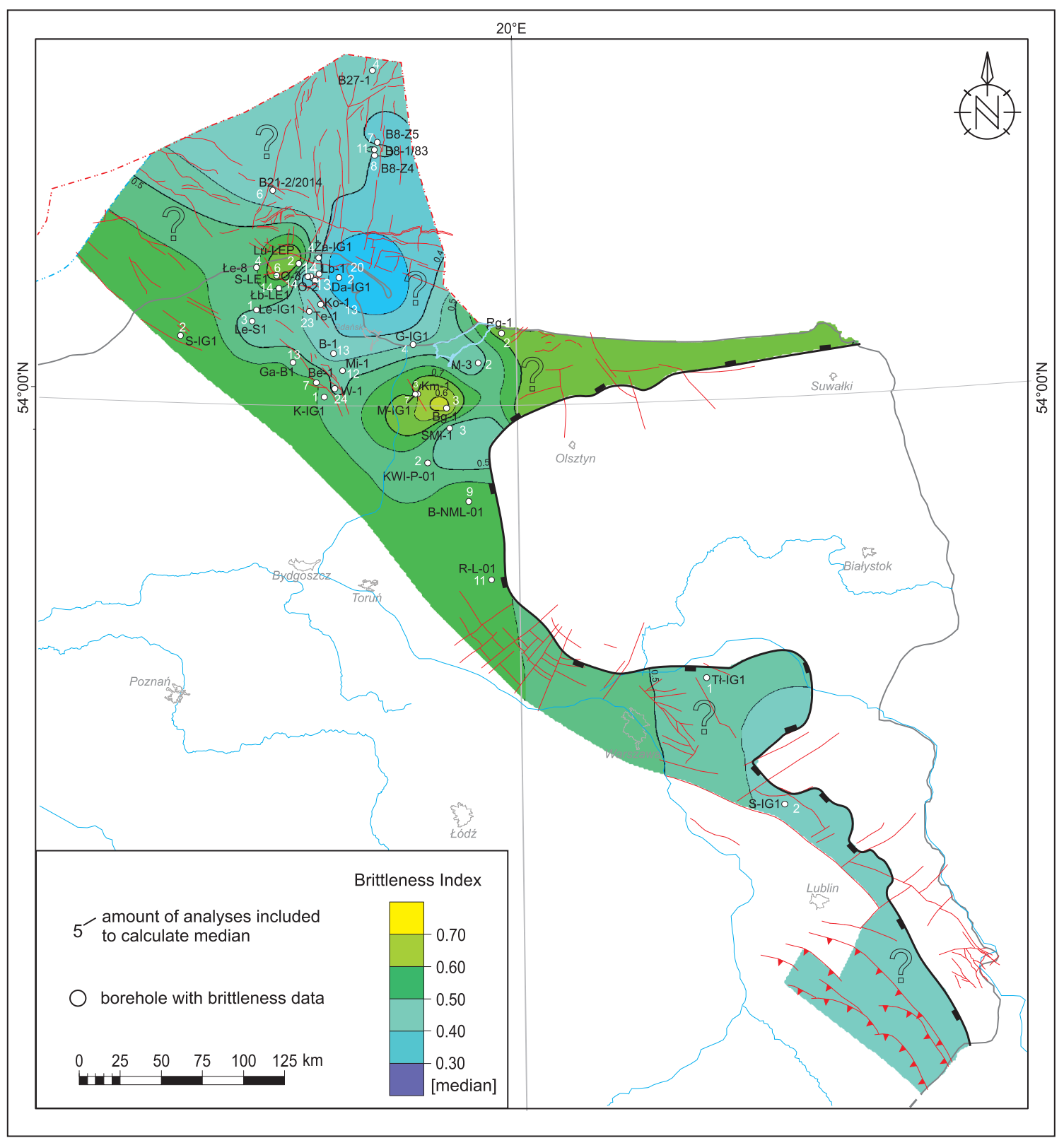

Fig. 22. Brittleness index map for the Jantar Formation

Other explanations on Figures 5 and 6

\section{CHARACTERISTICS OF PZ4}

STRATIGRAPHY AND LITHOLOGY

PZ4 was distinguished in several isolated occurrences in the eastern part of the Baltic-Podlasie-Lublin Basin in the lower part of the Pelplin Formation corresponding to different biostratigraphic zones of the Wenlock (Fig. 23). The lower boundary of PZ4 usually corresponds to the lower boundary of the Wenlock and the lower boundary of the Pelplin Formation. The largest thickness was noted to the east of Warsaw area, e.g. in boreholes Kałuszyn 1 and Tłuszcz IG 1 (Fig. 23).

The succession of strata in PZ4 is characterized by a small vertical variability of lithological-sedimentological features. Black-grey clayey siltstones and laminated claystones domi- nate (lithofacies of set L-4, see Feldman-Olszewska and Roszkowska-Remin, 2016), often calcareous, with graptolites. Characteristic are early diagenetic limestone concretions and occasional very thin tuffite/bentonite laminae. A trend of increasing contribution of carbonate material towards the east of the zone is significant.

\section{PETROGRAPHY AND MINERALOGY}

Rocks from PZ4 in light microscopy are characterized by grey-brown claystones, locally silty or calcareous. The claystones display a directional texture, emphasized by parallel distribution of clay minerals or laminae of organic matter, and with a muddy or muddy/silty composition. The pelitic fraction comprises clay minerals (illite, mixed-layered illite/smectite miner- 


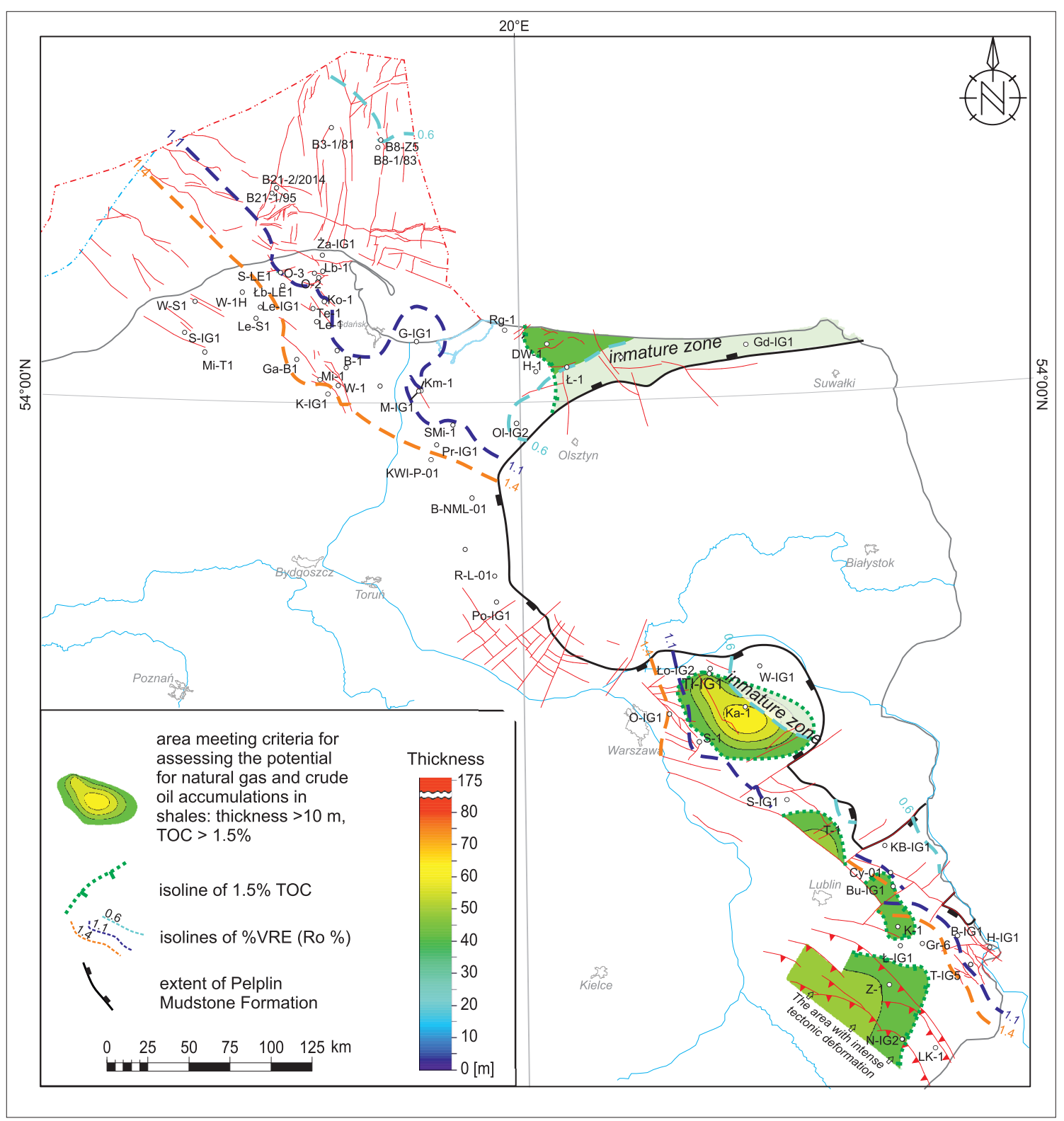

Fig. 23. PZ4 map

Abbreviations of boreholes not cited on Figures 5-7: Grabowiec 6 - Gr-6, other explanations on Figures 5-7, 14 and 21

als, chlorites). XRD analysis indicated the presence of mixed-layered chlorite/vermiculite minerals. Carbonate micrite is also present. Carbonates occur also as sub- and anhedral crystals, represented mainly by calcite. The admixture of detrital material is represented by quartz, potassium feldspars and sporadically plagioclase grains. Concentration of pyrite and individual occurrences of bioclasts have also been noted (Sikorska-Jaworowska et al., 2016; Kuberska, 2018).

\section{GEOCHEMISTRY AND THERMAL MATURITY} OF THE ORGANIC MATTER

The lower part of the Pelplin Formation (corresponding to $50 \mathrm{~m}$ of the basal part of the formation giving the possibility of inter-comparison between the boreholes) in PZ4 comprises clayey siltstone rocks with a significantly high dispersion of or- ganic matter and rather poor in TOC compared to all the formations discussed above. The TOC content is from $\sim 0.5$ to slightly $>2$ wt. $\%$ (poor to good source quality) (Table 2). The highest TOC values (>2 wt. \%) were noted in the Podlasie part of the basin near the Grębków area. Values from 1.5 to 2 wt. \% were noted within PZ4 near the Dębowiec Warmiński area in the north, and the Lublin Basin and Biłgoraj-Narol Zone (Fig. 24). The OSI is from $>20$ to $>60 \mathrm{mg} \mathrm{HC} / \mathrm{g}$ TOC (early mature to mature source rocks; Table 5). The largest OSI values (>50 mg HC/g TOC) were observed near the Debowiec Warmiński and Żebrak areas qualitatively indicating higher oil saturations (Fig. 25).

In the northern part of PZ4 near the Żelazna Góra and Dębowiec Warmiński areas $\left(T_{\max }>430^{\circ} \mathrm{C}\right)$, in the southern part of PZ4 in the Podlasie Basin $\left(T_{\max }>440^{\circ} \mathrm{C}\right)$, and in the northern part of the Lublin Basin near the Siedliska and Wojcieszków areas 


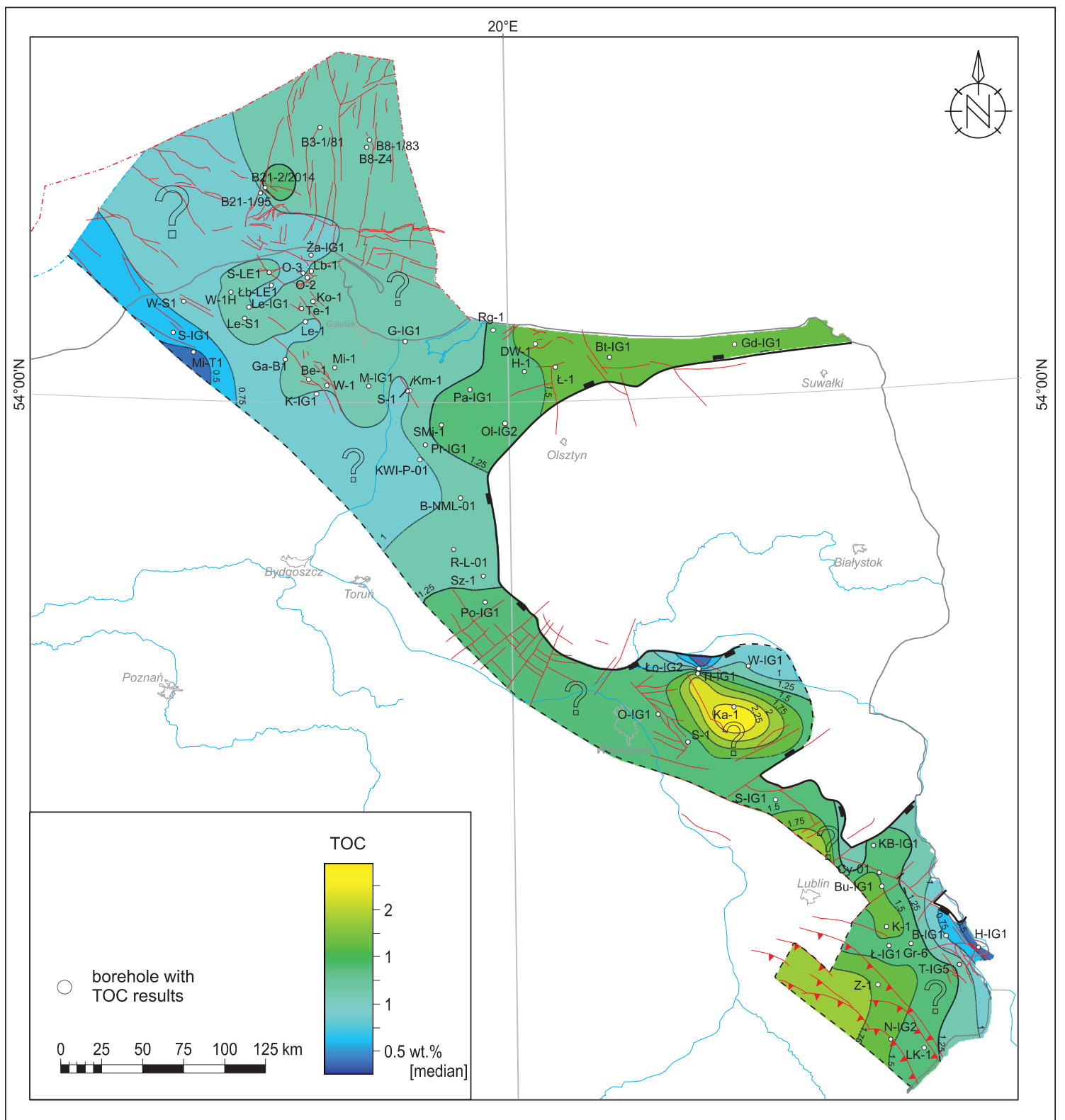

Fig. 24. Total Organic Carbon map for the Pelplin Formation

Other explanations on Figures 5-7 and 23

$\left(T_{\max }>440^{\circ} \mathrm{C}\right)$, the organic matter of the Pelplin Formation is in oil window (Table 3). To the south of PZ4 in the Lublin Basin, near the Cyców and Krupe areas, $T_{\max }$ values exceed $460^{\circ} \mathrm{C}$ (wet gas window), and in the Busówno $\left(T_{\max }>480^{\circ} \mathrm{C}\right)$ and Grabowiec areas $\left(T_{\max }>520^{\circ} \mathrm{C}\right)$, a probable dry gas window is interpreted. The dry gas window or maybe a zone with a degree of thermal transformation too high for the preservation of shale gas occurs also in the Narol area $\left(T_{\max }>550^{\circ} \mathrm{C}\right)$.

The interpretation of thermal maturity of organic matter based on $T_{\max }$ values in PZ4 is again in accordance with the results of reflectivity of vitrine-like macerals, recalculated to the vitrinite reflectivity scale (\%VRE; Jacob, 1989; Makos et al., 2016).
Dispersed amorphous or dark streaks of organic matter distributed in rocks of the Pelplin Formation represent oil-prone type II kerogen.

AVERAGE TOTAL GAS CONTENT

The median values of the total gas content in SP4 exceed $1.5 \mathrm{~m}^{3} / \mathrm{t}$ only near the Grabowiec area. Comparable values of total gas content were obtained from deposits of the lower parts of the Pelplin Formation also in the Baltic Basin, where other prospective criteria have not been fulfilled. 


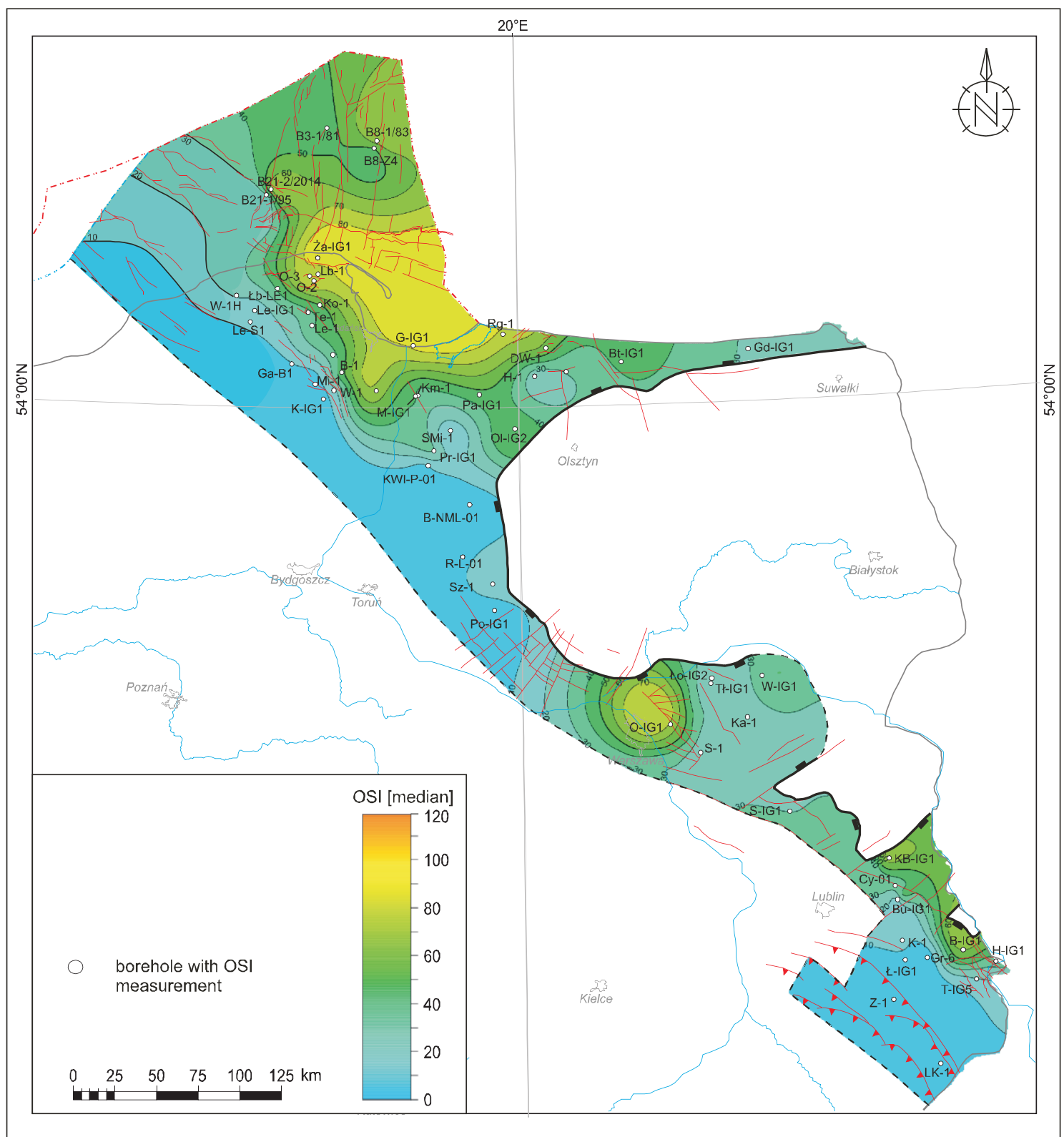

Fig. 25. Oil Saturation Index map for the Pelplin Formation

Other explanations on Figures 5-7 and 23

GEOMECHANICS

PZ4 shows the highest homogeneity among all prospective zones analysed. The YM measured parallel to bedding oscillates around $\sim 65 \mathrm{GPa}$, whereas the PR was estimated at 0.235. The measurements of these parameters in a direction perpendicular to bedding were $41.6 \mathrm{GPa}$ and 0.22 , respectively. The tensile strength determined on borehole cores perpendicular to bedding was $10.5 \mathrm{MPa}$, whereas parallel to bedding the TS was 4.7 MPa, higher than in PZ2 and PZ3. The formation $\mathrm{BI}$ ranges from 0.55 to 0.6 . The rocks analysed are susceptible to propagation of vertical fractures during hydraulic fracturing operations.

\section{DISCUSSION}

The Early Paleozoic basin on the western slope of the EEC has been recognized as one of the most prospective areas for shale and oil exploration in Middle and Eastern Europe (e.g., Poprawa, 2010; Karcz et al., 2013; Anthonsen et al., 2016; Schovsbo et al., 2017; Fig. 26). On the basis of a combination of thermal maturity with TOC content the prospectivity of the Sasino, Jantar, Pasłęk and Peplin formations across the Baltic-Podlasie-Lublin basin has been confirmed lately by Papiernik et al. (2019). 


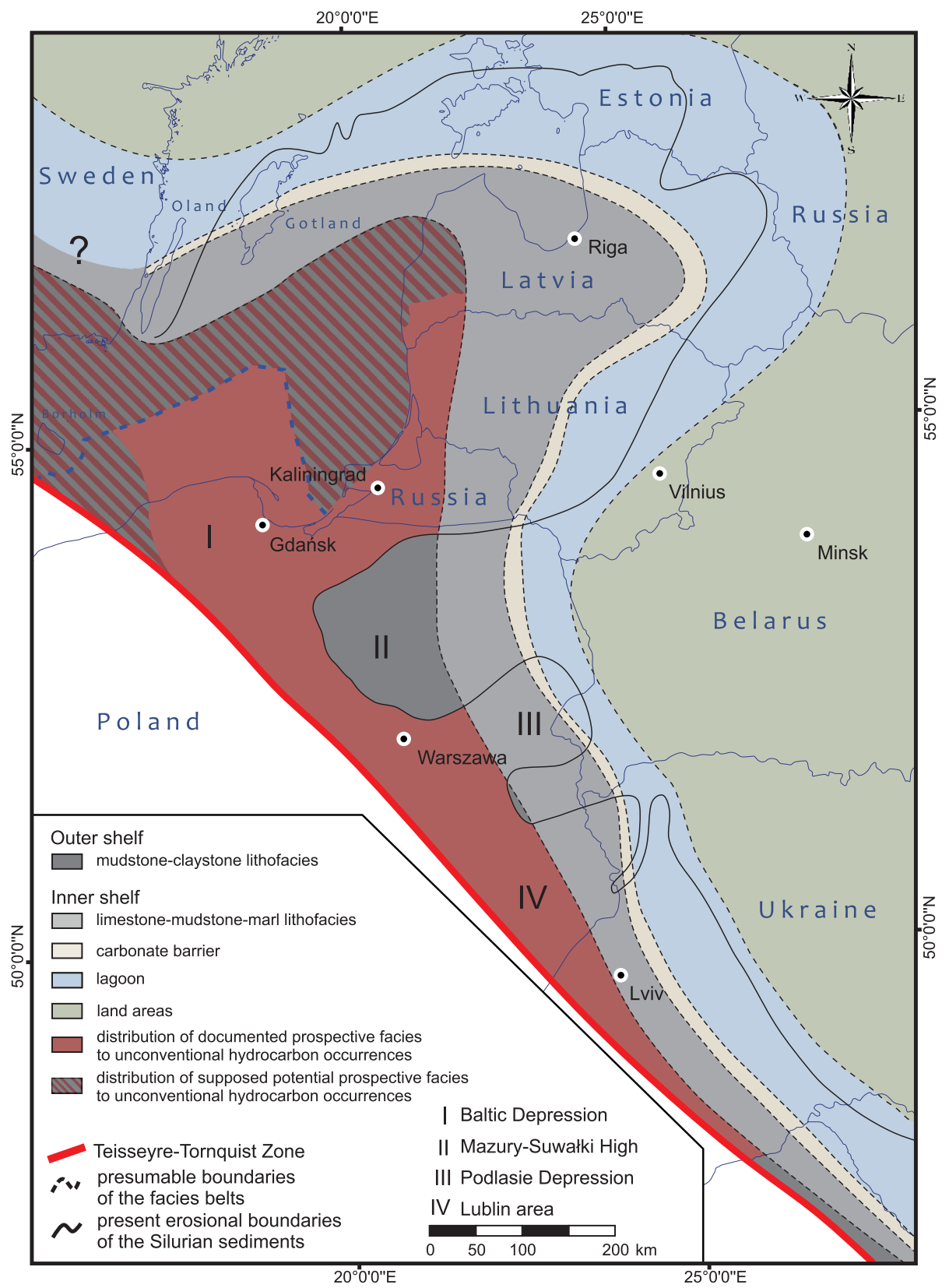

Fig. 26. Schematic distribution of lithofacies in the Early Paleozoic sedimentary basin along the western edge of the East European Craton in the Silurian (based on Teller, 1996; Zdanavičiũtė and Lazauskienè, 2009; Modliński, 2010; Radkovets, 2015; Anthonsen, 2016)

The presence and migration of depositional environments in the sedimentary basin conducive to the deposition of fine-grained sediments enriched in organic matter was conditioned by both the tectonic evolution of the basin from Ediacaran rifting to Caledonian orogenesis (e.g., Lazauskiene et al., 2003a, b; Poprawa, 2006, 2019) and by global factors associated with climate and eustatic changes in relative sea level along with their effects on biological productivity (Armstrong et al., 2009; Loydell et al., 2009; Podhalańska, 2009; Masiak et al., 2020).

The Furongian to Early Ordovician sedimentation in the western part of the Baltic Basin is related to the post-rift thermal subsidence of the passive continental margin of Baltica (Poprawa and Pacześna, 2002). The Furongian and Lower Tremadocian bituminous shales of the Piaśnica Formation with limestone interbeds and rich in TOC represent shelf muds, deposited in anoxic or suboxic conditions and their maturity increases to the SW towards the TTZ (Kosakowski et al., 2017). A Lower Tremadocian black shale (Białowieża Formation) is documented also in the northern part of the Podlasie Depression (Szymański, 1984). The present-day range of the uppermost Cambrian-lowermost Ordovician rocks in Poland is restricted by erosion.

The development of black shale facies with numerous graptolites of the Sasino Formation is related to global sea level rise in the Late Ordovician. In the Sandbian and Katian the relative sea level was the highest ever in the whole geological history of the Earth (Nielsen, 2004). The "blooms" of graptolite plankton were mainly associated with fertile areas of the rim of 
the continental shelf and their maxima correspond with periods of transgression and high relative sea level. Upwelling zones of high primary productivity, responsible for the bloom of phytoand zooplankton constitute the main area of graptolite development (Finney and Berry, 1999) and the deposition of black shales.

The lower boundary of the Sasino Formation is diachronous in the Polish part of the sedimentary basin and constitutes a marine flooding surface, highlighted by a sedimentary discontinuity, pyritic erosional surface, condensation, phosphatization of the organic particles and the presence of the iron pisoids (Podhalańska, 1980, 2009).

The condensation and mass appearance of graptolites characteristic of the bottom part of the Sasino Formation are manifestations of marine inundation and mark a parasequence boundary in the sedimentary record of the Ordovician Baltic Ba$\sin$. In the Baltic-Podlasie-Lublin Basin the Late Ordovician marine transgression began earliest in the western part of the area and advanced gradually towards the east and south-east. Towards the east, and thus towards the proximal parts of the sedimentary basin, the Ordovician deposits are replaced by limestones or marls with a smaller proportion of graptolitic shales (Modliński, 2010; Modliński and Podhalańska, 2010).

Transgression which began by the end of the Ordovician during the persculptus Chron is reflected in the Early Llandovery by the deposition of black graptolite-bearing shales of the Jantar Formation. The deposition of the organic-rich black shales was a synchronous event of Rhuddanian age over wide areas. At the opposing margin of the Rheic Ocean organic-rich black shales were deposited along the Gondwana shelf forming the most important petroleum source rocks in north Africa and the Arabian Peninsula (Lüning et al., 2000). This organic-rich, condensed, "hot", clay-dominated graptolitic shales with high total organic carbon (TOC) values and pyritic framboids indicate an anoxic event which may be related to the initial postglacial transgression event (Lüning et al., 2000; Podhalańska, 2009). The results of carbon and oxygen stable isotope studies (Podhalańska, 2009) indicate considerable changes in the isotope composition of sea water in the Late Ordovician and Early Silurian corresponding to the oceanic and ecological events across the O/S boundary. General trends in the carbon isotope curve of the sections from the central and eastern part of the Baltic Depression (Podhalańska, 2009) are analogues to curves from other parts of the Baltica as well as from other palaeocontinents (e.g., Kaljo et al., 2004; Saltzman and Young, 2005). According to Lazauskiené at al. (2003b) the Llandovery transgression coincided with the beginning of the flexural bending of the western margin of the EEC.

A preliminary stratigraphic model proposed by Porębski et al. (2013) suggests "...the deposition of the Llandovery-Ludlow mudrocks in the outer part of a pericratonic shelf ramp that was gradually downlapped from the west by gently inclined silty clinoforms fed from an orogenic source...." The maximum TOC abundance seems to occur in the distal part of the ramp and organic matter is gradually diluted farther away by carbonate (to the NE) and siliciclastic (to the SW) material (Porębski et al., 2013).

Unconventional accumulations of hydrocarbons in the Lower Paleozoic shale rocks are speculated to be present also in other regions of the sedimentary Baltic Basin, in the extension to the central part of the basin and to Ukraine of the organic matter-rich formations defined in Poland.

Rocks of various ages, which can be considered as potentially prospective for the occurrence of unconventional hydrocarbon accumulations, both onshore and offshore of the Baltic Sea, have been recognized in Lithuania, the Kaliningrad region
(Russia), Latvia and in its extension towards the south, in Ukraine. Their occurrence is associated with the accumulation of mudstones enriched in organic matter in the open shelf zone (Fig. 26).

Levels of exploration of deposits believed to be potential source rocks for hydrocarbons, and the scope of the resulting scientific studies, are not uniform in the EEC area.

\section{LITHUANIA}

Mostly terrigenous, fine-grained rocks dominate in the Upper Ordovician and Silurian in the western and central part of Lithuania; these grade into marlstones, dolomites and limestones in the east (Zdanavičiũtė and Lazauskienè, 2009). The major shale hydrocarbon potential in Lithuania is related to the organic-rich rocks distributed in the western part of the country, the Upper Ordovician and the Lower Silurian (Llandovery and ?Wenlock) successions. They are related to the outer shelf facies and constitute a continuation to the NE of the lower part of the Upper Ordovician-Lower Silurian mudstone-rich successions known from Poland. An Upper Ordovician succession of Katian age (Middle-Late Caradoc) is composed of black and grey shales of the Mossen and Fjäcka formations. Black claystone intervals of the Ordovician Mossen an Fjäcka Formations have been interpreted as deposits of 3rd order transgressive (TST) and highstand (HST) system tracts (Dronov et al., 2011). The Fjäcka and the Mossen formations may be considered as the age equivalents of the upper part of the Sasino Formation in Poland. The total thickness of these formations varies from 9 to $20 \mathrm{~m}$, TOC content is in the range of 0.9 to $10 \%, T_{\max }$ is $>420^{\circ} \mathrm{C}$. The source rock facies were recognized as of kerogen type II (Zdanavičiũtè and Bojesen-Koefoed, 1997; Cichon-Pupienis et al., 2020).

The Lower Silurian succession comprises dark grey and black graptolite shales and dark grey and black clayey marls of the Aeronian and Telychian stages (Llandovery), which lie on top of carbonates of the lowermost Silurian (Rhuddanian). The Llandovery Jürmala Formation (Paškevičius, 1997) is probably an equivalent of the Pasłęk Formation in the Polish part of the Baltic Basin and its lowermost part, the Dobele Formation (Aeronian), may be probably considered as an lithofacies equivalent of the Jantar Formation in the western part of the Baltic Basin in Poland. According to Cichon-Pupienis et al. (2020) the deposition of the highly organic matter-rich Lower Silurian Dobele Formation, might have coincided with oceanic anoxia and a Late Aeronian bioevent, accompanied by an upwelling regime with increased palaeoproductivity. Comparison shows the Lithuanian part of the sedimentary basin and the basins in the western part of Poland to have similar shale gas prospects; the Polish part of the basin shows, however, higher thermal maturity of the organic matter and Lithuanian part is characterized by more favourable depth and thickness of the Lower Silurian shale succession (Šliaupa et al., 2016). The Wenlock section in the western part of Lithuania is represented by dark graptolite shales and clayey marlstones. The occurrence depth of the Lower Silurian base increases to the southwest, ranging from $200 \mathrm{~m}$ in the east to nearly $2050 \mathrm{~m}$ in the westernmost part of Lithuania (Lazauskienè et al., 2003a; Zdanavičiũtè and Lazauskienè, 2009). The thickness of the Llandovery shales varies from 15 to $80 \mathrm{~m}$. The TOC ranges from 0.2 to $11 \%$, occasionally reaching $19 \%$. The most organic-rich shales occur within the Aeronian strata and decrease gradually to the top of the shale succession. The maturity of the organic matter is from 0.6 to $1.94 \%$ and increases to the south-west to the edge of the EEC, what is in agreement with the overall trend in the Baltic Basin. 


\section{KALININGRAD REGION (RUSSIA)}

In Russia's Kaliningrad region located in the northeastern extension of the Polish part of the Baltic Basin the presence of technically recoverable shale oil and shale gas resources has been estimated by prospective firms and noted in a report of the EIA (2015). The Kaliningrad region, along with the surrounding areas, northern Poland and partially Lithuania, was located during the Silurian in the outer shelf zone within the mudstone-claystone lithofacies (Fig. 26). The Svita Grivinska and the lower part of the Svita Brusowska are the equivalents of the Pasłęk Formation (Modliński et al., 2006). Results of geological surveying indicate that the strata of hydrocarbon source rocks in the region mainly include Silurian dark grey marl and anhydrite. The thickness of these layers, especially in the western part of the region, reaches $\sim 60 \mathrm{~m}$. This is comparable with a typical thickness of oil source strata elsewhere.

\section{LATVIA}

Four potential shale oil/gas formations (Lower and Upper Ordovician, Llandovery) at a depth of 1500-1700 m have been determined in Latvia, but only the Zebrus Formation (Anthonsen et al., 2016; Schovsbo et al., 2017) corresponds to some of the EUOGA (EU Unconventional Oil and Gas Assessment) criteria, as this Lower Ordovician formation lies deeper than $1.5 \mathrm{~km}$ and is $>20 \mathrm{~m}$ thick. The formation is, however, immature and no thermogenic resource is expected (Anthonsen et al., 2016) No activity regarding exploration and development of shale hydrocarbon resources is ongoing or planned. Based on general petroleum geology studies of the organic-rich shale formations, carried out in 1990s by the Geological Survey of Latvia, the country might have minor shale hydrocarbon resources (Anthonsen et al., 2016; Schovsbo et al., 2017).

\section{UKRAINE}

The Silurian shale succession of the EEC southwestern margin within the Ukrainian territory is seen as a potential target for both conventional and unconventional hydrocarbon occurrences (Krupskiy et al., 2014; Radkovets et al., 2017). The Lviv-Volyn Basin of western Ukraine was in the Early Paleozoic a continuation to the south-east of the Lublin part of the sedimentary basin in Poland (Fig. 26). According to Rizun et al. (2007) the Silurian sequence is represented by Wenlock, Ludlow and Pridoli deposits. Similarly to the Lublin region, in the area located nearest to the edge of the EEC, the outer shelf facies dominates. The lithological sections of the Volyn-Podillyan Plate (VPP), a western gas-bearing region (Krupskiy et al., 2014), consist of clay with a small amount of carbonate organic-rich rocks typical of outer shelf facies. Within the VPP, the Silurian deposits are subdivided into three lithofacies: outer shelf, reef facies and lagoonal facies (Radkovets, 2015). The open (outer) shelf facies from the edge of the EEC are represented by clay-carbonate-siliceous rocks often enriched with dispersed organic matter. The argillites are dark grey to black, unevenly calcareous, pyritized, with graptolites. West from the TTZ, an equivalent of the folded rocks of the Koszalin-Chojnice Zone in Poland occur. The strata recognized in Ukraine west of the TTZ are defined by Radkovets (2015) as "Silurian flysch". From the west to the east some changes in lithology are observed. Along with argillites, more marlstones and clayey limestones appear, showing the transition from deep water clay to shallower carbonate facies. In the easternmost part of the VPP, the Silurian sections include thick reef limestones of carbonate barrier facies of various ages from the Wenlock to the Middle Pridoli. Both the outer-shelf and reef facies are prospective for hydrocarbons (Radkovets, 2015). The Ludlow formations of the Silurian are considered the most prospective interval.

The thickness of the open shelf facies in the VPP (argillites and limy argillites) is $\sim 1000$ metres in the most western part and decreases to $100 \mathrm{~m}$ towards the south-east. Total Organic Carbon usually ranges from 0.2 to $1 \%$, locally exceeding $2 \%$. Similarly, in the Lublin part of the basin in Poland, a large thickness and type II kerogen allow considering the Silurian rocks as prospective for shale gas exploration (Krupskiy et al., 2014; Radkovets, 2015).

In Ukraine, the geological reserves of shale hydrocarbon resources have been explored, with research and exploration conducted for gas and oil production from shales. Assessments have been performed for several areas in Ukraine, involving both the national geological survey and third parties (Anthonsen et al., 2016).

\section{CONCLUSIONS}

The stratigraphic ranges and boundaries of $\mathrm{PZ1-PZ4}$ are described, distinguished on the basis of accepted criteria in the Lower Paleozoic strata of the EEC in Poland. The range of PZ1 corresponds in the offshore area and on the northern part of the Łeba Elevation to part of the Piaśnica Formation, PZ2 distinguished on the Łeba Elevation corresponds only in a small part to the Sasino Formation. PZ3 distinguished mainly on the northern part of the Łeba Elevation onshore and offshore and in a small part of the Biłgoraj-Narol Zone corresponds only partly to the lateral extent of the Jantar Formation, and PZ4 corresponds to the lower part of the Pelplin Formation in several separate areas of the Podlasie-Lublin part of the basin.

Stratigraphic research has provided more details of the temporal and spatial ranges of the lithostratigraphic formations and prospective zones. The number and range of stratigraphic gaps in the Ordovician-Silurian succession increase towards the east and south-east. In the Podlasie-Lublin area a large stratigraphic gap spans the part of the Llandovery and increases eastwards.

The characteristic feature of the Lower Paleozoic deposits at the EEC margin in Poland is the diachronous appearence of some black shale formations from the west to the east.

The stratigraphic range of the Middle/Upper Ordovician Sasino Formation in the western part of the EEC decreases to the east and south-east. While in the marginal part of the Baltic Basin the Sasino Formation encompasses the Upper Darriwilian, Sandbian and lower Katian (Llanvirn to uppermost Caradoc), in the central part of the Baltic Depression and in the Podlasie and Lublin regions, it comprises only the Katian Stage (Upper Caradocian) with the Dicranograptus clingani and Climacograptus styloideus graptolite biozones.

The base of Llandovery deposits, the Jantar Formation or the Pasłęk Formation, is diachronous. The stratigraphic range of the Jantar Formation in the marginal (western) part of the area is wider than previously thought and spans not only the Rhuddanian but also part of the Aeronian. Towards the eastern and southeastern part of the Baltic-Podlasie-Lublin Basin the base of the Llandovery succession, often with a thin layer of the bituminous shales in the lowermost part, is dated by the Aeronian graptolite biozones. In the boreholes located yet farther east the Landovery shale formations are replaced by 
Telychian claystones and marls enriched at the bottom with organic matter (increased TOC value) or containing thin organic intercalations in their lower part.

Due to the very high TOC content and geochemical characteristics, the Piaśnica Formation within PZ1 is the primary petroleum source rock in the Polish part of the Baltic Basin. Prospective PZ2, (partly corresponding to the Sasino Formation), over a large part of the Baltic Basin, despite not being an uniform unit, is the next important prospective unit. To the east and south-east of Poland, the Sasino Formation does not comprise source rocks and is not considered as prospective in the context of unconventional resources.

The Jantar Formation in the range of $\mathrm{PZ} 3$ is a secondary petroleum source rock in the Polish part of the Baltic Basin. On the northern offshore part of the Łeba Elevation and in the eastern part of the Baltic Depression, the Jantar Formation shows improvement of parameters of source properties. The location of areas in the Polish part of the Baltic Basin, in which the units discussed (particularly the Piaśnica, Sasino and Jantar formations) are characterized by the best properties pointing to source areas, are probably places of hydrocarbon generation. In the southernmost part of the study area (the Biłgoraj-Narol Zone) very good source properties occur also in the Rhuddanian Jantar Formation (southern part of PZ3).

The lower part of the Pelplin Formation (PZ4) may be considered as a good petroleum source rock only in the central part of the Baltic Depression (Warmia-Masuria area), Podlasie Depression and Lublin region.

Interpretation of the data obtained and their visualization on maps has allowed precise definition of the regional total organic carbon content (TOC), oil saturation index (OSI), thermal maturity of organic matter $\left(T_{\max }\right)$, and type of primary kerogen in the shale formations discussed. The maps provided of distribution of the geochemical parameters TOC, OSI, average gas content, $T_{\max }$ and VRE display the latest state of knowledge on the petroleum systems of the Baltic-Podlasie-Lublin Basin and were used to distinguish the most current ranges of prospective zones of occurrence of unconventional oil and gas reservoirs in Lower Paleozoic shale formations in Poland.

Due to the high volume of clay minerals and TOC in relation to brittle component contents, the application of stimulation treatments in prospective zones may be challenging. Particular attention should be paid to the internal geomechanical diversity of the Jantar and Sasino formations where zones of reduced susceptibility to the development of hydraulic fractures occur. The volatile tectonic regime and low differential stresses mean that the exploration boreholes should be subjected to detailed geomechanical analyses to help determine the exploitation potential of the area.

Updated regional thermal maturity studies have shown that majority of shale gas exploration boreholes in the Polish part of the Baltic Basin have been drilled within the oil window zone, whilst borehole locations in the wet gas and dry gas window zones could have resulted in a better exploration results.

Comparison with the other areas within the Lower Paleozoic Baltic Basin reveals the shale formations that may constitute a potential source of hydrocarbons are diachronous. Towards the east and south-east, ever younger deposits possess the potential for hydrocarbon accumulations. In Poland, in the western part of the EEC, these are: Furongian and the lowest Ordovician (Tremadocian) deposits, Sandbian and Katian Sasino Formation and Llandovery (Rhuddanian and Aeronian) Jantar Formation. In the central part of Baltic Basin (Lithuania), these are the Upper Ordovician Mossen and Fjäcka formations and the Aeronian Dobele Formation as well as Wenlock shales. In the southeastern part of the basin (Ukraine), the Ludlow is considered to be the most promising in terms of potential unconventional hydrocarbon accumulations.

Despite the common shale heterogeneity some similarities can be seen, such as the marine type of depositional environment with the predominance of type II kerogen and specific organic matter content in all prospective regions of the sedimentary basin extending in the Early Paleozoic around the palaeocontinent Baltica.

Acknowledgements. The authors are greatly indebted to the reviewers: Dr. J. Lazauskiene and Dr. P. Dziadzio, for their valuable comments which helped to improve the manuscript. The present studies are based on the results of investigations performed in 2013-2018 by PGI-NRI in the frame of the project "Recognition of prospective zones for the occurrence of unconventional hydrocarbon reservoirs in Poland. Continuous task of Polish Geological Survey" financed by the National Fund for Environmental Protection and Water Management. Petrel, Techlog and Petromod software, shared by Schlumberger Information Solution with PGI-NRI for scientific-research activities, were used in the analyses.

\section{REFERENCES}

Andrews, I.J., 2013. The Carboniferous Bowland Shale Gas Study: Geology and Resource Estimation. British Geological Survey for Department of Energy and Climate Change, London, UK.

Andrews, I.J., 2014. The Jurassic Shales of the Weald Basin: Geology and Shale Oil and Shale Gas Resource Estimation. British Geological Survey for Department of Energy and Climate Change, London, UK.

Anthonsen, K.L., Schovsbo, S., Britze, P., 2016. Overview of the Current Status and Development of Shale Gas and Shale Oil in Europe. Report T3b of the EUOGA study (EU Unconventional Oil and Gas Assessment) commissioned by JRC-IET to GEUS.

Armstrong, H.A., Abbot, G.D., Turner, B.R., Makhlouf, I.M., Muhammad, A.B., Pedentchouk, N., Peters, H., 2009. Black shale deposition in an Upper Ordovician-Silurian permanently stratified, peri-glacial basin, southern Jordan. Palaeogeography, Palaeoclimatology, Palaeoecology, 273: 368-377.

Behar, F., Beaumont, V., De Penteado, B.H.L., 2001. Rock Eval 6 technology: performances and development. Oil and Gas Science and Technology, 56: 111-134.

Cichon-Pupienis, A., Littke, R., Froidl, F., Lazauskiené, J., 2020. Depositional history, source rock quality and thermal maturity of Upper Ordovician-Lower Silurian organic-rich sedimentary rocks in the central part of the Baltic Basin (Lithuania). Marine and Petroleum Geology, 112: https://doi.org/10.1016/j.marpetgeo.2019.104083

Cocks, L.R.M., 2000. The early Palaeozoic geography of Europe. Journal of the Geological Society, 157: 1-10.

Cooper, R.A., Sadler, P.M., Hammer, O., Gradstein, F.M., 2012. The Ordovician period. In: Geologic Time Scale 2012, 2 (eds. 
F.M. Gradstein, J.G. Ogg, M.D. Schmitz and G.M. Ogg): 489-523. Elsevier, Amsterdam.

Cyz, M., Mulińska, M., Pachytel, R.W., Malinowski, M., 2018. Brittleness prediction for the lower Paleozoic shales in northern Poland. Interpretation, 6: $\mathrm{SH} 13-\mathrm{SH} 23$.

Dembicki, H., 2017. Practical Petroleum Geochemistry for Exploration and Production. 1st Edition, Elsevier.

Dronov, A., Ainsaar, I., Kaljo, D., Meidla, T., Saadre, T., Einasto, T., 2011. Ordovician of Baltoscandia: facies, sequence and sea-level changes. Ordovician World, 14: 143-150.

Dyrka, I., 2016. Petrophysical and mineralogical characterization of prospective hydrocarbon complexes estimated based on selected laboratory research results (in Polish with English summary). Przegląd Geologiczny, 64: 982-986.

EIA (U.S. Energy Information Administration), 2011. Analysis and Projections. World shale gas resources: an initial Assessment of 14 regions outside the Unites States. U.S. Energy Information Administration.

EIA, 2013. Technically Recoverable Shale Oil and Shale Gas Resources: An Assessment of 137 Shale Formations in 41 Countries Outside the United States. U.S. Energy Information Administration Washington DC

Espitalié, J., Deroo, G., Marquis, F., 1985. La pyrolyse Rock-Eval et ses applications. Oil and Gas Science and Technology, 40: 563-579.

Farzin, M.H., Krizek, R.J., Corotis, R.B., 1975. Evaluation of modulus and Poisson's ratio from triaxial tests. 54th Annual Meeting of the Transportation Research Board, Washington DC.

Feldman-Olszewska, A., Roszkowska-Remin, J., 2016. Lithofacies of the Ordovician and Silurian formations prospective for shale gas/oil in the Baltic and Podlasie-Lublin areas (in Polish with English summary). Przeglad Geologiczny, 64: 968-975.

Finney, S.C., Berry, W.B.N., 1999. Late Ordovician graptolite extinction: the record from continental margin sections in central Nevada, USA. Acta Universitatis Carolinae - Geologica, 43: 195-198.

Gąsior, I., Skupio, R., Dohnalik, M., 2016. Methodology for determining the organic matter content in the lower Palaeozoic and Carboniferous deposits for archival boreholes (in Polish with English summary). Przegląd Geologiczny, 64: 987-994.

Golonka, J., Porebskki, S.J., Barmuta, J., Papiernik, B., Bebenek, S., Barmuta, M., Botor, D., Pietsch, K., Słomka, T., 2019. Palaeozoic palaeogeography of the East European Craton (Poland) in the framework of global plate tectonics. Annales Societatis Geologorum Poloniae, 89: 381-403.

Grotek, I., 2016. A petrologic study and thermal maturity of organic matter from the Cambrian, Ordovician and Silurian deposits in the Baltic and Podlasie-Lublin areas (in Polish with English summary). Przegląd Geologiczny, 64: 1000-1004.

Jaanusson, V., 1976. Faunal dynamics in the Middle Ordovician (Viruan) of Balto-Scandia. In: The Ordovician System: Proceedings of a Palaeontological Association Symposium, Birmingham, 1974: 301-326.

Jacob, H., 1989. Classification, structure, genesis and practical importance of natural solid oil bitumen (migrabitumen). International Journal of Coal Geology, 11: 65-79.

Janas, M., 2016. Analiza pirolityczna utworów dolnego paleozoikuobszar podlasko-lubelski (in Polish). In: Rozpoznanie stref perspektywicznych dla występowania niekonwencjonalnych złóż weglowodorów w Polsce, etap I (eds. T. Podhalańska, A. Becker, I. Dyrka, A. Feldman-Olszewska, A. Głuszyński, I. Grotek, T. Grudzień, M. Janas, P. Karcz, E. Klimuszko, H. Kiersnowski, A. Kozłowska, A. Kuberska, Z. Modliński, G. Nowak, J. Pacześna, M.G. Roman, J. Roszkowska-Remin, M. Sikorska-Jaworowska, L. Skowroński, K. Sobień and M.I. Waksmundzka). Opracowanie końcowe: Inw. 4878/2016. NAG, Państwowy Instytut Geologiczny, Warszawa.

Janas, M., 2018. Analiza wyników badań geochemicznych materii organicznej metodami Rock-Eval, SRA i LECO (in Polish). In: Rozpoznanie stref perspektywicznych dla występowania nie- konwencjonalnych złóż węglowodorów w Polsce, stałe zadanie psg, Il etap (eds. T. Podhalańska, T. Adamczak-Biały, A. Becker, I. Dyrka, A. Feldman-Olszewska, A. Głuszyński, I. Grotek, M. Janas, K. Jarmołowicz-Szulc, M. Jachowicz, P. Karcz, E. Klimuszko, A. Kozłowska, E. Krzyżak, A. Kuberska, G. Nowak, R. Pachytel, J. Pacześna, M. Roman, M. Sikorska-Jaworowska, L. Skowroński, K. Sobień, W. Trela, A. Trzepierczyńska, M.I. Waksmundzka, K. Wołkowicz and A. Wójcicki). Opracowanie końcowe: Inw. 9051/2019. NAG, Państwowy Instytut Geologiczny, Warszawa.

Jarvie, D.M., 2008. Geochemical Characteristics of the Devonian Woodford Shale. Worldwide Geochemistry: 1-23.

Jarvie, D.M., 2012. Shale resource systems for oil and gas. Part $1-$ Shale gas. Resource Systems. AAPG Memoir, 97: 69-87.

Jarvie, D.M., Baker, D.R., 1984. Application of the Rock-Eval III Oil Show Analyzer to the study of gaseous hydrocarbons in an Oklahoma gas well. 187th ACS National Meeting, St. Louis, Missouri, USA, 8-13 April 1984.

Jaworowski, K., 2000. Facies analysis of the Silurian shale-siltstone succession in Pomerania. Geological Quarterly, 44 (3): 297-315.

Jaworowski, K., 2002. Profil dolnego paleozoiku w północnej Polsce - zapis kaledońskiego stadium rozwoju basenu bałtyckiego (in Polish). Posiedzenia Naukowe Państwowego Instytutu Geologicznego, 58: 9-10.

Kaljo, D., 2004., Hints, L., Martma, T., Nölvak, J., Oraspold, A., 2004. Late Ordovician carbon isotope trend in Estonia, its significance in stratigraphy and environmental analysis. Palaeogeography, Palaeoclimatology, Palaeoecology, 210: 165-185.

Karcz, P., 2016. Analiza pirolityczna utworów dolnego paleozoiku obszar bałtycki (in Polish). In: Rozpoznanie stref perspektywicznych dla występowania niekonwencjonalnych złóż węglowodorów w Polsce, etap I (eds. T. Podhalańska, A. Becker, I. Dyrka, A. Feldman-Olszewska, A. Głuszyński, I. Grotek, T. Grudzień, M. Janas, P. Karcz, E. Klimuszko, H. Kiersnowski, A. Kozłowska, A. Kuberska, Z. Modliński, G. Nowak, J. Pacześna, M.G. Roman, J. Roszkowska-Remin, M. Sikorska-Jaworowska, L. Skowroński, K. Sobień and M.I. Waksmundzka). Opracowanie końcowe: Inw. 4878/2016. NAG, Państwowy Instytut Geologiczny, Warszawa.

Karcz, P., Janas, M., 2016. Organic matter in Cambrian, Ordovician and Silurian shales of the Baltic-Podlasie-Lublin Basin in Poland (in Polish with English summary). Przegląd Geologiczny, 64: 995-999.

Karcz, P., Janas, M., Dyrka, I., 2013. Polish shale gas deposits in relation to selected shale gas perspective area of central and eastern Europe (in Polish with English summary). Przegląd Geologiczny, 61: 411-423.

Kias, E., Maharidge, R., Hurt, R., 2015. Mechanical Versus Mineralogical Brittleness Indices Across Various Shale Plays. Society of Petroleum Engineers 174781. doi:10.2118/174781-MS

Klimuszko, E., 2018. Charakterystyka materii organicznej w utworach dolnego paleozoiku na obszarze syneklizy bałtyckiej i obszarze Lubelszczyzny (in Polish). In: Rozpoznanie stref perspektywicznych dla wystepowania niekonwencjonalnych złóż węglowodorów w Polsce, stałe zadanie psg, II etap (eds. T. Podhalańska, T. Adamczak-Biały, A. Becker, I. Dyrka, A. Feldman-Olszewska, A. Głuszyński, I. Grotek, M. Janas, K. Jarmołowicz-Szulc, M. Jachowicz, P. Karcz, E. Klimuszko, A. Kozłowska, E. Krzyżak, A. Kuberska, G. Nowak, R. Pachytel, J. Pacześna, M. Roman, M. Sikorska-Jaworowska, L. Skowroński, K. Sobień, W. Trela, A. Trzepierczyńska, M.I. Waksmundzka, K. Wołkowicz and A. Wójcicki). Opracowanie końcowe: Inw. 9051/2019. NAG, Państwowy Instytut Geologiczny, Warszawa.

Koren, T.N., Lenz, A.C., Loydell, D.K., Melchin, M.J., Štorch, P., Teller, L., 1996. Generalized graptolite zonal sequence defining Silurian time intervals for global paleogeographics studies. Lethaia, 29: 59-60.

Kosakowski, P., Kotarba, M.J., Piestrzyński, A., Shogenova, A., Więcław, D., 2017. Petroleum source rock evaluation of the Alum and Dictyonema Shales (Upper Cambrian-Lower Ordovician) in 
the Baltic Basin and Podlasie Depression (eastern Poland). International Journal of the Earth Sciences, 106: 743-761.

Kotarba, M.J., 2010. Origin of hydrocarbon gases accumulated in the Middle Cambrian reservoirs of the Polish part of the Baltic region. Geological Quarterly, 54 (2): 197-204.

Krupskiy, Yu.Z., Kurovets, I.M., Senkovskiy, Yu.M., Mikhaiylov, V.A., Chepil', P.M., Drigant, D.M., Shlapins'kiy, V.Ye., Koltun, Yu.V., Chepil', V.P., Kurovets, S.S., Bodlak, V.P., 2014. Unconventional sources of hydrocarbons of Ukraine. Western gas-bearing region: Volyn-Podillya oil- and gas-bearing region: 27-46. Prospects of gas presence in shale formations of Volyn-Podillya area: 91-180, Kyiv, Nika-Centre.

Kuberska, M., 2018. Badania mineralogiczno-petrograficzne skał w wyselekcjonowanych fragmentach rdzeni wiertniczych i horyzontach stratygraficznych wraz z analizą i interpretacją wyników badań. Basen bałtycko-podlasko-lubelski (in Polish). In: Rozpoznanie stref perspektywicznych dla występowania niekonwencjonalnych złóż węglowodorów w Polsce, stałe zadanie psg, etap II (eds. T. Podhalańska, T. Adamczak-Biały, A. Becker, I. Dyrka, A. Feldman-Olszewska, A. Głuszyński, I. Grotek, M. Janas, K. Jarmołowicz-Szulc, M. Jachowicz, P. Karcz, E. Klimuszko, A. Kozłowska, E. Krzyżak, A. Kuberska, G. Nowak, R. Pachytel, J. Pacześna, M. Roman, M. Sikorska-Jaworowska, L. Skowroński, K. Sobień, W. Trela, A. Trzepierczyńska, M.I. Waksmundzka, K. Wołkowicz and A. Wójcicki). Opracowanie końcowe: Inw. 9051/2019. NAG, Państwowy Instytut Geologiczny, Warszawa.

Lazauskiené, J., Šliaupa, S., Musteikis, P., Brazauskas, A., 2003a. Sequence stratigraphy of the Baltic Silurian succession: tectonic control on the foreland infill. Geological Society Special Publications, 208: 95-115.

Lazauskiené, J., Stephenson, R., Šliaupa, S., van Wees, J.D., 2003b. 3-D flexural modelling of the Silurian Baltic Basin. Tectonophysics, 346: 115-135

Loydell, D.K., Butcher, A., Fryda, J., Lüning, S., Fowler, M., 2009. Lower Silurian "Hot" shales in Jordan: a new depositional model. Journal of Petroleum Geology, 32: 261-270.

Lüning, S., Craig, J., Loydell, D., Štorch, P., Fitches, B., 2000. Lower Silurian "hot shales" in North Africa and Arabia: regional distribution and depositional model. Earth Science Review, 49: $121-200$.

Makos, M., Muchewicz, M., Mikołajewski, Z., Socha, K., 2016. Thermal maturity of the lower Paleozoic source rocks in the Pomeranian Basin based on reflectance of vitrinite-like particles and molecular/isotope gas composition. Conference abstracts book. Geopetrol, Zakopane, 2016.

Masiak, M., Stempień-Sałek, M., Podhalańska, T., 2020. Microphytoplankton from middle palaeolatitudes of southern hemisphere - a record from climate change strata of Baltica's O/S boundary. Geological Quarterly, 64 (1): 86-103.

Mazur, S., Porębski, S.,J., Kędzior, A., Paszkowski, M., Podhalańska, T., Poprawa, P., 2018. Refined timing and kinematics for Baltica-Avalonia convergence based on the sedimentary record of a foreland basin. Terra Nova, 31: 8-16.

Melchin, M.J., Sadler, P.M., Cramer, B.D., Cooper, R.A., Gradstein, F.M., Hammer, O., 2012. The Silurian Period. In: Geologic Time Scale 2012, 2 (eds. F.M. Gradstein, J.G. Ogg, M.D. Schmitz and G.M. Ogg): 525-558. Elsevier, Amsterdam.

Michael, G.E., Packwood, J., Holba, A., 2014. Determination of in-situ hydrocarbon volumes in liquid-rich shale plays. Search and Discovery Article \#80365 (2014). Posted March 10, 2014

Modliński, Z., 1973. Stratigraphy and development of the Ordovician in North-Eastern Poland (in Polish with English summary). Prace Instytutu Geologicznego, 72: 7-74.

Modliński, Z., 1984. Stratigraphy of post-Tremadocian Ordovician rocks in the Lublin region (in Polish with English summary). Kwartalnik Geologiczny, 28: 1-16.

Modliński, Z. ed., 2007. Introduction (in Polish with English summary), In: Profile głębokich Otworów Wiertniczych Państwowego Instytutu Geologicznego, 116: 5-7.

Modliński, Z. ed., 2010. Paleogeological atlas of the sub-Permian Paleozoic of the East-European Craton in Poland and neighboring areas. PIG-NRI, Warszawa.
Modliński, Z. (ed.), 2011. Introduction (in Polish with English summary) In: Profile głębokich Otworów Wiertniczych Państwowego Instytutu Geologicznego, 128: 7-9.

Modliński, Z., Szymański, B., 1997. The Ordovician lithostratigraphy of the Peribaltic Depression (NE Poland). Geological Quarterly, 41 (3): 273-288.

Modliński, Z., Szymański, B., 2005. The Ordovician lithostratigraphy of the Biłgoraj-Narol area (Southern Poland) (in Polish with English summary). Biuletyn Państwowego Instytutu Geologicznego, 416: 45-79.

Modliński, Z., Szymański, B., 2008. Lithostratigraphy of the Ordovician in the Podlasie Depression and the basement of the Płock-Warsaw trough (Eastern Poland) (in Polish with English summary). Biuletyn Państwowego Instytutu Geologicznego, 430: 79-112.

Modliński, Z., Podhalańska, T., 2010. Outline of the lithology and depositional features of the lower Paleozoic strata in the Polish part of the Baltic region. Geological Quarterly, 54 (2): 109-121.

Modliński, Z., Szymański, B., Teller, L., 2006. The Silurian lithostratigraphy of the Polish part of the Peri-Baltic depression (N Poland) (in Polish with English summary). Przegląd Geologiczny, 54: 787-796.

Nielsen, A., T., 2004. Ordovician sea-level changes: a Baltoscandian perspective. In: The Great Ordovician Biodiversification Event (eds. B.D. Webby, F. Paris, M.L. Droser and L.G. Percival): 84-93. Columbia University Press.

Pachytel, R.W., Jarosiński, M., Bobek, K., 2017. Geomechanical stratification in a shale reservoir and its correlation with natural fractures: case from Pomeranian Basin (Poland). 51st U.S. Rock Mechanics/Geomechanics Symposium, ARMA: 17-77.

Papiernik, B., Bator, D., Golonka, J., Porębski, S.J., 2019. Unconventional hydrocarbon prospects in Ordovician and Silurian mudrocks of the East European Craton (Poland): insight from three-dimensional modeling of total organic carbon and thermal maturity. Annales Societatis Geologorum Poloniae, 89: 511-533.

Paškevičius, J., 1997. The geology of the Baltic Republics. Geological Survey of Lithuania, Vilnius.

Peters, K.E., 1986. Guidelines for evaluating petroleum source rock using programmed pyrolysis. AAPG Bulletin, 70: 318-329.

PIG-PIB, 2012. Ocena zasobów wydobywalnych gazu ziemnego i ropy naftowej w formacjach łupkowych dolnego paleozoiku w Polsce (basen bałtycko-podlasko-lubelski), Raport pierwszy (in Polish). https://www.pgi.gov.pl/docman-tree-all/aktualnosci2012/zasoby-gazu/771-raport-pl/file.html

Podhalańska, T., 1980. Stratigraphy and development of Middle and Upper Ordovician deposits in the Łeba Elevation (NW Poland). Acta Geologica Polonica, 30: 327-390.

Podhalańska, T., 2009. The Late Ordovician Gondwana glaciation - a record of environmental changes in the depositional succession of the Baltic Depression (Northern Poland) (in Polish with English summary). Prace Państwowego Instytutu Geologicznego, 193: 1-196.

Podhalańska, T., 2019. Graptolite biostratigraphy and dating of the Ordovician-Silurian shale succession of the SW slope of the East European Craton. Annales Societatis Geologorum Poloniae, 89: 429 - 452.

Podhalańska, T., Modliński, Z., Szymański, B., 2010. Nowelizacja stratygrafii syluru brzeżnej części kratonu wschodnioeuropejskiego (obszar Lubelszczyzny i Podlasia) (in Polish). NAG, no. 1268764. Państwowy Instytut Geologiczny, Warszawa.

Podhalańska, T., Becker, A., Dyrka, I., Feldman-Olszewska, A., Głuszyński, A., Grotek, I., Grudzień, T., Janas, M., Karcz, P., Klimuszko, E., Kiersnowski, H., Kozłowska, A., Kuberska A., Modliński, Z., Nowak, G., Pacześna, J., Roman, M.G., Roszkowska-Remin, J., Sikorska-Jaworowska, M., Skowroński, L., Sobień, K., Waksmundzka, M.I., 2016a. Rozpoznanie stref perspektywicznych dla występowania niekonwencjonalnych złóż weglowodorów w Polsce, etap I (in Polish). Opracowanie końcowe $z$ realizacji projektu. Inw. 4878/2016. NAG, Państwowy Instytut Geologiczny, Warszawa.

Podhalańska, T., Waksmundzka, M.I., Becker, A., Roszkowska-Remin, J., Dyrka, I., Feldman-Olszewska, A., Głuszyński, A., Grotek, I., Janas, M., Karcz, P., Nowak, G., Pacześna, 
J., Roman, M., Sikorska-Jaworowska, M., Kuberska, M., Kozłowska, A., Sobień, K., 2016b. Prospective zones for unconventional hydrocarbon resources in Cambrian, Ordovician, Silurian and Carboniferous rocks in Poland - integration of the research results (in Polish with English summary). Przegląd Geologiczny, 64: 1008-1022.

Podhalańska, T., Waksmundzka, M.I., Becker, A., Roszkowska-Remin, J., 2016c. Investigation of the prospective areas and stratigraphic horizons of the unconventional hydrocarbon resources in Poland - new results and future research directions (in Polish with English summary). Przegląd Geologiczny, 64: 953-962.

Podhalańska, T., Adamczak-Biały, T., Becker, A., Dyrka I., Feldman-Olszewska, A., Głuszyński, A., Grotek, I., Janas, M., Jarmołowicz-Szulc, K., Jachowicz, M., Karcz, P., Klimuszko, E., Kozłowska, A., Krzyżak, E., Kuberska, A., Nowak, G., Pachytel, R., Pacześna, J., Roman, M., Sikorska-Jaworowska, M., Skowroński, L., Sobień, K., Trela, W., Trzepierczyńska A., Waksmundzka, M. I., Wołkowicz, K., Wójcicki, A., 2018. Rozpoznanie stref perspektywicznych dla występowania niekonwencjonalnych złóż węglowodorów w Polsce, stałe zadanie psg, etap II (in Polish). Opracowanie końcowe: Inw. 9051/2019. NAG, Państwowy Instytut Geologiczny, Warszawa.

Polish Journal of Laws, 2015, p. 968 (in Polish).

Poprawa, P., 2006. Development of the Caledonian collision zone along the western margin of Baltica and its relations to the foreland basin (in Polish with English summary). Prace Państwowego Instytutu Geologicznego, 186: 189-214.

Poprawa, P., 2010. Shale gas potential of the lower Palaeozoic complex in the Baltic and Lublin-Podlasie basins (Poland) (in Polish with English summary). Przegląd Geologiczny, 58: 226-249.

Poprawa, P., 2019. Geological setting and Ediacaran-Palaeozoic evolution of the western slope of the East European Craton and adjacent regions. Annales Societatis Geologorum Poloniae, 89: 347-380.

Poprawa, P., Pacześna, J., 2002. Late Neoproterozoic to Early Palaeozoic development of a rift at the Lublin-Podlasie slope of the East European Craton - analysis of subsidence and facies record (eastern Poland) (in Polish with English summary). Przeglad Geologiczny, 50: 49-63.

Poprawa, P., Šliaupa, S., Stephenson, R.A., Lazauskiené, J., 1999. Late Vendian-Early Palaeozoic tectonic evolution of the Baltic basin: regional implications from subsidence analysis. Tectonophysics, 314: 219-239.

Porebska, E., Kozłowska-Dawidziuk, A., Masiak, M., 2004. The lundgreni event in the Silurian of the East European Platform, Poland. Palaeogeography, Palaeoclimatology, Palaeoecology, 213: 271-294.

Porębski, S.J., Podhalańska, T., 2019. Ordovician-Silurian lithostratigraphy of the East European Craton in Poland. Annales Societatis Geologorum Poloniae, 89: 95-104

Porębski, S.J., Prugar, W., Zacharski, J., 2013. Silurian shales of the East European Platform in Poland - some exploration problems (in Polish with English summary). Przeglad Geologiczny, 61: 630-638

Radkovets, N., 2015. The Silurian of southwestern margin of the East European Platform (Ukraine, Moldova and Romania): lithofacies and palaeoenvironments. Geological Quarterly, 59 (1): 105-118.

Radkovets, N., Rauball, J., laremchuk, I., 2017. Silurian black shales of Western Ukraine: petrography and mineralogy. Estonian Journal of Earth Sciences, 66: 161-173.

Rizun, B., Pavlyuk, M., Medvedev, A., Kinakh, M., 2007. Silurian buried reefs of Volyn-Podillya in the context of oil and gas prospectives (in Ukrainian with English summary). Geologija Geokhimiya Goryuchykh Kopalyn, (4): 5-25.

Roman, M., 2016. Interpretation and visualization of well data in the lower Palaeozoic of the East European Craton and in the Car- boniferous of the Fore-Sudetic Homocline basement (in Polish with English summary). Przegląd Geologiczny, 64: 976-981.

Ruble, T., Drozd, R.J., Heck, W.A., 2012. Practical Geochemical Methods to Assess Unconventional Reservoirs. A Case Study from the Permian Basin, Texas. Weatherford Laboratories presentation.

Rystad Energy, 2010. Poland seen as exploratory hot spot for 5 year. Oil and Gas Journal, 105, 46.

Saltzman, M.R., Young, S.A., 2005. Long-lived glaciation in the Late Ordovician? Isotopic and sequence-stratigraphic evidence from the western Laurentia. Geology, 33: 109-112.

Schovsbo, N.H., Anthonsen, K.L., Pedersen, C.B., Tougaard, L., 2017. Overview of shale layers characteristics in Europe relevant for assessment of unconventional resources. Delivery T6b of the EUOGA study (EU Unconventional Oil and Gas Assessment) commissioned by JRC-IET to GEUS

Sikorska-Jaworowska, M., Kuberska, M., Kozłowska, M., 2016. Petrography and mineralogy of the lower Palaeozoic shales from the East European Craton and Carboniferous sandstones from the basement of the Fore-Sudetic Homocline (in Polish with English summary). Przeglad Geologiczny, 64: 963-967.

Šliaupa, S., Šlaupienè, R., Zalũdienè, G., Vaskaboinikava, T., Babikava, A., Evstratenko, L., Kovkhuto, A., 2016. Prospects of Lithuanian Silurian shale gas, Baltic sedimentary Basin. Oil Shale, 33: 357-372.

Szymański, B., 1984. Tremadocian and Arenigian deposits in North-Eastern Poland (in Polish with English summary). Prace Instytutu Geologicznego, 118: 5-88.

Szymański, B., Modliński, Z., 2003. Revision of the Silurian stratigraphy in selected boreholes from the Polish sector of the Baltic Depression (Northern Poland) (in Polish with English summary). Biuletyn Państwowego Instytutu Geologicznego, 405: 109-138.

Teller, L., 1997. The subsurface Silurian in the East European Platform. Palaeontologia Polonica, 56: 7-21.

Tissot, B.P., Welte, D.H., 1984. Petroleum Formation and Occurrence. Springer, Berlin.

Tomczyk, H., 1990. Sylur (in Polish). In: Budowa Geologiczna Polski, 3 - Atlas skamieniałości przewodnich i charakterystycznych, cz. 1a, Paleozoik starszy (z proterozoikiem górnym) (ed. M. Pajchlowa): 272-279. Wyd. Geol., Warszawa.

Ulusay, R., Hudson, J.A., 2007. The Complete ISRM Suggested Methods for Rock Characterization, Testing and Monitoring: 1974-2006. Elsevier.

Urbanek, A., Teller, L., 1997. Graptolites and stratigraphy of the Wenlock and Ludlow Series in the East European Platform. Palaeontologia Polonica, 56: 23-57.

Więcław, D., Kotarba, M.J., Kosakowski, P., Kowalski, A., Grotek, I., 2010a. Habitat and hydrocarbon potential of the lower Paleozoic source rocks in the Polish part of the Baltic region. Geological Quarterly, 54 (2): 159-182.

Więcław, D., Kotarba, M.J., Kowalski, A., 2010b. Origin of oils accumulated in the Middle Cambrian reservoirs of the Polish part of the Baltic region. Geological Quarterly, 54 (2): 205-2016.

Wójcicki, A., Dyrka I., Kiersnowski, H., Adamczak-Biały, T., Becker, A., Głuszyński, A., Janas, M., Karcz, P., Kozłowska, A., Kuberska, M., Pacześna, J., Podhalańska, T., Skowroński, L., Waksmundzka, M.I., 2017. Prognostyczne zasoby gazu ziemnego i ropy naftowej w skałach łupkowych dolnego paleozoiku w basenie bałtycko-podlasko-lubelskim i w strefie Biłgoraj-Narol w Polsce (in Polish). In: Szacowanie zasobów złóż węglowodorów - zadanie ciagłe psg, I etap (eds. Wójcicki et al.). Opracowanie końcowe: Inw. 9046/2019. NAG, Państwowy Instytut Geologiczny, Warszawa.

Zdanavičiũtè, O., Bojesen-Koefoed, J.A., 1997. Geochemistry of Lithuanian oils and source rocks: a preliminary assessment. Journal of Petroleum Geology, 20: 381-402.

Zdanavičiũtė, O., Lazauskienè, J., 2009. Organic matter of Early Silurian succession - the potential source of unconventional gas in the Baltic Basin (Lithuania). Baltica, 22: 89-99. 